\title{
Polybaric fractional crystallisation of arc magmas: an experimental study simulating trans-crustal magmatic systems
}

\author{
Felix Marxer ${ }^{1,2}$ (D) Peter Ulmer ${ }^{1}$ (D) $\cdot$ Othmar Müntener $^{3}(\mathbb{D}$
}

Received: 25 June 2021 / Accepted: 19 October 2021 / Published online: 7 December 2021

(c) The Author(s) 2021

\begin{abstract}
Crystallisation-driven differentiation is one fundamental mechanism proposed to control the compositional evolution of magmas. In this experimental study, we simulated polybaric fractional crystallisation of mantle-derived arc magmas. Various pressure-temperature trajectories were explored to cover a range of potential magma ascent paths and to investigate the role of decompression on phase equilibria and liquid lines of descent (LLD). Fractional crystallisation was approached in a step-wise manner by repetitively synthesising new starting materials chemically corresponding to liquids formed in previous runs. Experiments were performed at temperatures ranging from 1140 to $870{ }^{\circ} \mathrm{C}$ with $30^{\circ} \mathrm{C}$ steps, and pressure was varied between 0.8 and $0.2 \mathrm{GPa}$ with $0.2 \mathrm{GPa}$ steps. For most fractionation paths, oxygen fugacity $\left(\mathrm{fO}_{2}\right)$ was buffered close to the $\mathrm{Ni}-\mathrm{NiO}$ equilibrium (NNO). An additional fractionation series was conducted at $\mathrm{fO}_{2}$ corresponding to the $\mathrm{Re}-\mathrm{ReO}_{2}$ buffer $(\mathrm{RRO} \approx \mathrm{NNO}+2)$. High-pressure experiments $(0.4-0.8 \mathrm{GPa})$ were run in piston cylinder apparatus while $0.2 \mathrm{GPa}$ runs were conducted in externally heated pressure vessels. Resulting liquid lines of descent follow calc-alkaline differentiation trends where the onset of pronounced silica enrichment coincides with the saturation of amphibole and/or Fe-Ti-oxide. Both pressure and $\mathrm{fO}_{2}$ exert crucial control on the stability fields of olivine, pyroxene, amphibole, plagioclase, and $\mathrm{Fe}-\mathrm{Ti}$-oxide phases and on the differentiation behaviour of arc magmas. Key observations are a shift of the olivine-clinopyroxene cotectic towards more clinopyroxene-rich liquid composition, an expansion of the plagioclase stability field and a decrease of amphibole stability with decreasing pressure. Decompression-dominated ascent trajectories result in liquid lines of descent approaching the metaluminous compositional range observed for typical arc volcanic rocks, while differentiation trends obtained for cooling-dominated trajectories evolve to peraluminous compositions, similar to isobaric liquid lines of descent at elevated pressures. Experiments buffered at RRO provide a closer match with natural calc-alkaline differentiation trends compared to $\mathrm{fO}_{2}$ conditions close to $\mathrm{NNO}$. We conclude that decompression-dominated fractionation at oxidising conditions represents one possible scenario for arc magma differentiation.
\end{abstract}

Keywords Arc magmatism $\cdot$ Magma differentiation $\cdot$ Fractional crystallisation $\cdot$ Calc-alkaline rocks $\cdot$ Polybaric differentiation $\cdot$ Liquid line of descent

\section{Introduction}

Communicated by Dante Canil.

Felix Marxer

f.marxer@mineralogie.uni-hannover.de

1 Institute of Geochemistry and Petrology, ETH Zürich, Clausiusstrasse 25, 8092 Zürich, Switzerland

2 Institute of Mineralogy, Leibniz University Hannover, Callinstraße 3, 30167 Hannover, Germany

3 Institute of Earth Sciences (ISTE), University of Lausanne, Bâtiment Géopolis, 1015 Lausanne, Switzerland
Calc-alkaline magmatism is characteristic for active convergent plate margins and is related to the formation and evolution of continental and island arc crust. Calc-alkaline volcanic and plutonic rocks range from basalt/gabbro to intermediate andesite/tonalite to highly differentiated silicarich rhyolite or granite. Consequently, the calc-alkaline differentiation trend is characterised by a strong enrichment in $\mathrm{SiO}_{2}$ and alkalis and a depletion in $\mathrm{MgO}$ and $\mathrm{FeO}$ (e.g. Osborn 1962; Miyashiro 1974; Grove and Baker 1984). Despite decades of research, this compositional spread is still a matter of active debate (e.g. Clemens et al. 2011; 
Keller et al. 2015; Ulmer et al. 2018; Collins et al. 2020). Major, not mutually exclusive, mechanisms controlling arc magma differentiation include (1) mixing of magmas of various compositions (e.g. Tatsumi and Takahashi 2006; Reubi and Blundy 2009; Blatter et al. 2013), (2) assimilation of crustal lithologies by mafic magmas (e.g. DePaolo 1981; Hildreth and Moorbath 1988; Thompson et al. 2002), or (3) crystallisation-driven differentiation of primitive mantlederived basaltic magmas (e.g. Bowen 1915, 1928; Grove et al. 2003; Nandedkar et al. 2014; Ulmer et al. 2018). Since the fundamental work of Bowen (1928), a large number of studies have been conducted supporting as well as objecting the dominant control of fractional crystallisation on calcalkaline differentiation trends (e.g. Green and Ringwood 1968; Grove et al. 2003; Ulmer 2007; Turner and Langmuir 2015; Clemens et al. 2021). In detail, the most commonly invoked fractionating mineral phases controlling calc-alkaline differentiation include magnetite (e.g. Osborn 1959), amphibole (e.g. Cawthorn and O'Hara 1976; Foden and Green 1992; Sisson and Grove 1993a; Davidson et al. 2007; Dessimoz et al. 2012; Blatter et al. 2013; Nandedkar et al. 2014; Goltz et al. 2020), or garnet (e.g. Macpherson et al. 2006; Müntener and Ulmer 2006; Tang et al. 2018).

During the last decades, deep and shallow differentiation of parental mafic magmas via crystallisation has been investigated experimentally. A crucial observation of experimental high-pressure liquid lines of descent (0.7-1.2 GPa) established for fractional (Nandedkar et al. 2014; Ulmer et al. 2018) or equilibrium crystallisation (Müntener et al. 2001; Alonso-Perez et al. 2009; Blatter et al. 2013) is the rapid increase of the alumina saturation index ASI $\left(=\mathrm{Al}_{2} \mathrm{O}_{3} /\right.$ $\left.\left(\mathrm{CaO}+\mathrm{Na}_{2} \mathrm{O}+\mathrm{K}_{2} \mathrm{O}\right)\right)$ with ongoing differentiation resulting in peraluminous (ASI > 1) intermediate (andesitic) melt compositions. This general behaviour is the result of extensive clinopyroxene and amphibole crystallisation at high pressures depleting residual liquids efficiently in calcium but to a much lesser extent in alumina. However, the majority of intermediate volcanic and plutonic arc rocks are metaluminous and only highly evolved silica-rich lithologies become weakly peraluminous. On the contrary, liquid lines of descent defined at low pressure (0.2-0.4 GPa) via equilibrium crystallisation (Sisson and Grove 1993a, 1993b; Grove et al. 2003; Blatter et al. 2013) provide a closer match with the compositional trend exhibited by natural rocks and remain metaluminous upon progressive differentiation.

To resolve the open question of the predominant pressure level or crustal depth of crystallisation differentiation, we experimentally investigated the process of polybaric fractional crystallisation, where hydrous basaltic liquids extracted from the mantle differentiate at various levels in the crust (e.g. Grove et al. 2003; Almeev et al. 2013; Melekhova et al. 2015). Primary mantle-derived basaltic magmas buoyantly rise through the upper mantle and initiate differentiation via fractional crystallisation close to the crust-mantle boundary. Derivative evolved basaltic or andesitic liquids subsequently rise to the middle and upper crust and simultaneously continue to fractionate. Here we envisage that crystallisation differentiation occurs over a range of crustal pressures and temperatures generating different residual melt compositions. Since Clapeyron slopes of mineral reactions in calc-alkaline systems are rather different from near-adiabatic ascent trajectories (e.g. Blundy and Cashman 2001), different mineral boundaries are crossed during decompression. Most prominent and crucial for this study is a destabilisation of clinopyroxene at the expense of olivine with decreasing pressure via a displacement of the olivine-clinopyroxene cotectic curve towards melt compositions with higher normative clinopyroxene contents (e.g. Grove and Baker 1984; Grove et al. 1992; Stamper et al. 2014). In addition, decreasing pressure expands the stability field of plagioclase with respect to clinopyroxene and olivine preventing a pronounced enrichment of residual melts in alumina (e.g. Sisson and Grove 1993a; Grove et al. 2003; Alonso-Perez et al. 2009). Water solubility in silicate liquids diminishes with decreasing pressure (e.g. Hamilton et al. 1964) inferring that water activities $\left(\mathrm{aH}_{2} \mathrm{O}\right)$ continuously increase for $\mathrm{H}_{2} \mathrm{O}$-undersaturated hydrous arc magmas during decompression. Such a change in $\mathrm{aH}_{2} \mathrm{O}$ has an additional effect on plagioclase composition favouring the crystallisation of anorthite-rich plagioclase (e.g. Sisson and Grove 1993a). As a consequence of the combined effect of pressure-sensitive changes on phase equilibria, polybaric fractional crystallisation is expected to prevent calc-alkaline liquids to evolve towards peraluminous compositions at low $\mathrm{SiO}_{2}$, closer approaching the natural rock record.

Here we report the results of a set of polybaric fractional crystallisation experiments conducted on hydrous calc-alkaline basalts by varying pressure and temperature concomitantly along the liquid line of descent (LLD). We explored different polybaric fractionation ascent trajectories and conducted a limited number of additional experiments to evaluate the effect of oxygen fugacity $\left(\mathrm{fO}_{2}\right)$ and initial starting material composition on the resultant liquid lines of descent. We discuss the effect of polybaric fractionation on calc-alkaline magmas and propose a general petrological model for arc magma differentiation.

\section{Methods}

\section{General strategy}

Fractional crystallisation (FC) was simulated in a stepwise manner following established techniques (Villiger et al. 2004; Nandedkar et al. 2014; Ulmer et al. 2018): for each fractionation step, the chemical composition of the residual 
liquid (quenched to a homogeneous glass) of the respective experiment is determined by EPMA and a new, chemically corresponding starting material is synthesised employing pure chemicals. This starting material is then used for the subsequent experiment at different pressure-temperature conditions. Experiments were run between 1140 and $870{ }^{\circ} \mathrm{C}$, at pressures ranging from 1.0 to $0.2 \mathrm{GPa}$. Temperature steps of $30{ }^{\circ} \mathrm{C}$ (in a few cases $15{ }^{\circ} \mathrm{C}$ ) and pressure intervals of $0.2 \mathrm{GPa}$ were employed. The polybaric approach required that pressure and temperature had to be varied simultaneously. However, $\mathrm{P}-\mathrm{T}$ ascent trajectories of rising magmas through the crust are poorly constrained (e.g. Rutherford 2008; Neave and Maclennan 2020) and, therefore, three main experimental series with different $\mathrm{P}-\mathrm{T}$ trajectories have been investigated: (1) a hot path where each fractionation was linked to a decompression step simulating an ascent trajectory of $22.5^{\circ} \mathrm{C} / 0.1 \mathrm{GPa}$; (2) an intermediate path with one additional fractionation step performed under isobaric conditions $\left(30^{\circ} \mathrm{C} / 0.1 \mathrm{GPa}\right)$, and (3) a cold path where two isobaric fractionation steps were conducted between each decompression step $\left(45^{\circ} \mathrm{C} / 0.1 \mathrm{GPa}\right)$. An additional fractionation series (hot rk52 path) followed a similar P-T ascent trajectory as the hot path but initiated from a different starting material to test whether the normative clinopyroxene content of the primary starting material exerts a crucial impact on the resultant liquid line of descent during polybaric fractionation. Finally, a hot oxidised path (with an ascent trajectory of $19^{\circ} \mathrm{C} / 0.1 \mathrm{GPa}$ ) was explored, where $\mathrm{fO}_{2}$ was buffered close to the $\mathrm{Re}-\mathrm{ReO}_{2}$ equilibrium (RRO), while $\mathrm{fO}_{2}$ was constrained close to the Ni-NiO buffer (NNO) for all other series. The $\mathrm{P}-\mathrm{T}$ ascent trajectories given above were calculated by fitting a line through the first and last experiment of each fractionation series. Assuming an average crustal density of $2800 \mathrm{~kg} / \mathrm{m}^{3}$, the hot trajectories (hot, hot rk52, and hot oxidised path) simulate cooling rates of approx. $6-7{ }^{\circ} \mathrm{C} / \mathrm{km}$ during magma ascent, the intermediate path corresponds to $8{ }^{\circ} \mathrm{C} / \mathrm{km}$ and the cold path simulates $12{ }^{\circ} \mathrm{C} / \mathrm{km}$. Explored P-T trajectories are illustrated in Fig. 1, where fractionation steps are highlighted by an arrow and equilibrium steps are indicated by simple lines. Intermediate equilibrium crystallisation steps were required when less than $10 \mathrm{wt} . \%$ of minerals crystallised in the fractionation experiments to promote more extensive crystallisation prior to the execution of the next fractionation step.

\section{Starting materials}

Derivative liquids from the fractional crystallisation study at $1.0 \mathrm{GPa}$ by Ulmer et al. (2018) on a primitive high-Mg basalt from the Adamello Batholith (Northern Italy) were used as initial starting materials. Four fractionation series (hot, hot oxidised, intermediate, and cold path) were run on the residual liquid of the run rk54 $\left(1140{ }^{\circ} \mathrm{C}\right)$ exhibiting an

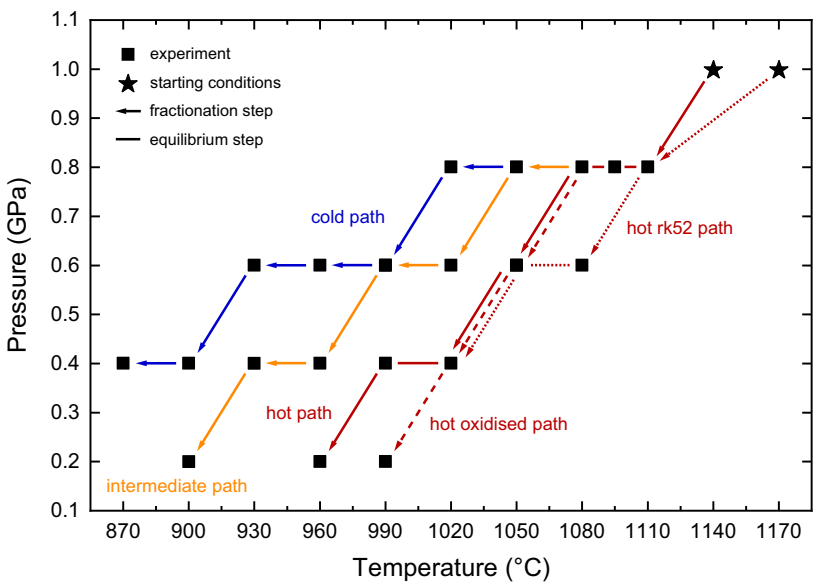

Fig. 1 Temperature-pressure diagram illustrating the five different ascent trajectories of polybaric fractionating magmas explored in this study. Arrows indicate fractionation steps, while lines correspond to equilibrium crystallisation steps

$\mathrm{xMg}$ of 0.585 , where $\mathrm{xMg}$ equals the molar ratio of $\mathrm{MgO} /$ $\left(\mathrm{FeO}_{\text {tot }}+\mathrm{MgO}\right)$, with all iron assumed to be ferrous. The hot rk52 path was performed on the melt formed in experiment $r k 52\left(1170{ }^{\circ} \mathrm{C}, \mathrm{xMg}\right.$ of 0.638$)$. Both compositions were derived from a primary high-Mg basalt (RC158c) via fractionation of the mineral phase assemblage olivine, clinopyroxene, and spinel. We slightly modified the liquid compositions reported by Ulmer et al. (2018) by adding $\mathrm{P}_{2} \mathrm{O}_{5}$ as a chemical component $(0.16 \mathrm{wt} . \%$ for rk54 and $0.13 \mathrm{wt} . \%$ for rk52) and decreasing $\mathrm{H}_{2} \mathrm{O}$ contents to $3.50 \mathrm{wt}$ \% (rk54) and $2.96 \mathrm{wt} . \%$ (rk52), respectively. For each fractionation step, $\mathrm{FeO}$ and $\mathrm{Na}_{2} \mathrm{O}$ (and in some cases also $\mathrm{K}_{2} \mathrm{O}$ and $\mathrm{P}_{2} \mathrm{O}_{5}$ ) contents of new starting materials were re-calculated from compositional data of experimental liquids and mineral phases employing phase proportions established by mass balance calculations to account for potential Fe-loss and alkali migration during EPMA analysis. $\mathrm{Fe}^{2+} / \mathrm{Fe}^{3+}$ ratios of starting materials were adjusted to values corresponding to the NNO or RRO oxygen buffers using the algorithm by Kress and Carmichael (1991). Water contents of starting materials were calculated by mass balance treating water as a perfectly incompatible compound in nominally anhydrous minerals and assuming an empirical $\mathrm{H}_{2} \mathrm{O}$ content of 2 wt.\% for amphibole. For low-pressure experiments $(0.2$ and $0.4 \mathrm{GPa}$ ), water contents of new starting materials were compared with expected water contents at saturation for respective experimental P-T conditions calculated by MagmaSat (Ghiorso and Gualda 2015) to avoid significant amounts (several wt.\%) of excess free water in the experimental charges influencing the silicate-fluid partitioning behaviour of some lithophile elements (e.g. Na and K). However, for the last starting material of the intermediate path (SM-FM160), the calculated $\mathrm{H}_{2} \mathrm{O}$ content via mass balance 
(8.1 wt.\%) was distinctly higher than the maximum $\mathrm{H}_{2} \mathrm{O}$ solubility at target experimental run conditions $\left(900{ }^{\circ} \mathrm{C}\right.$ and $0.2 \mathrm{GPa}$ ) inferred from MagmaSat (5.4 wt. \%) and, thus, the nominal water content of this starting material was lowered to $6.0 \mathrm{wt}$.\%. For each fractionation step, starting materials were prepared by accurately weighing fired $\left(1000{ }^{\circ} \mathrm{C}\right)$ or dried (110-220 $\left.{ }^{\circ} \mathrm{C}\right)$ oxides $\left(\mathrm{SiO}_{2}, \mathrm{TiO}_{2}, \mathrm{Al}_{2} \mathrm{O}_{3}, \mathrm{Fe}_{2} \mathrm{O}_{3}\right.$, $\mathrm{MnO}$, and $\mathrm{MgO}$ ), hydroxides ( $\mathrm{AlOOH}$ and $\mathrm{Al}(\mathrm{OH})_{3}$ ), phosphates (apatite), and silicates $\left(\mathrm{CaSiO}_{3}, \mathrm{Fe}_{2} \mathrm{SiO}_{4}, \mathrm{Na}_{2} \mathrm{SiO}_{3}\right.$, and $\mathrm{K}$-silicate). In addition, $2 \mathrm{wt} . \%$ of diopside glass, doped with 27 or 31 trace elements (LILE, HFSE, REE, transition metals, $\mathrm{U}$, and $\mathrm{Th}$ ) in the concentration of $2000 \mathrm{ppm}$ each (1000 ppm for $\mathrm{U}$ and $\mathrm{Th}$ ), were added to the starting materials resulting in $40 \mathrm{ppm}$, respectively $20 \mathrm{ppm}$ for $\mathrm{U}$ and $\mathrm{Th}$, in the final mixture. Trace elements were added to the starting materials to explore trace element partitioning during polybaric fractional crystallisation. Weighed-in compounds were homogenised under ethanol in an agate mortar for a minimum of two hours, and final powders were stored at $110^{\circ} \mathrm{C}$ before capsule preparation. Major element compositions of starting materials (in wt.\%) are provided in Table 1 and in the Electronic Supplementary Material ESM 1.

\section{Capsule design and capsule preparation}

A double capsule technique representing a modification and combination of the designs by Kaegi et al. (2005) and Matjuschkin et al. (2015) was employed, where two inner capsules (outer diameter, OD of $2.3 \mathrm{~mm}$ ) were placed in an outer capsule (OD of $4.0 \mathrm{~mm}$ ). The first inner capsule was prepared from $\mathrm{Au}_{90} \mathrm{Pd}_{10}$ or $\mathrm{Au}_{100}$ (below $1000{ }^{\circ} \mathrm{C}$ ) and contained the experimental charge. The second one was made of $\mathrm{Pt}$ and encased the solid-state buffer assemblage used to control $\mathrm{fO}_{2}$. A schematic sketch of the utilised capsule design is presented in the Electronic Supplementary Material ESM 2. NNO buffer mixtures were prepared from Ni metal and $\mathrm{Ni}(\mathrm{OH})_{2}$ powder in the molar proportions of 70:30, while RRO assemblages were made of Re metal and $\mathrm{ReO}_{2}$ powder with a ratio of 60:40. Higher metal proportions were used to account for potential alloying of $\mathrm{Ni}$ or Re metal with the $\mathrm{Pt}$ capsule walls and still warrant optimal $\mathrm{fO}_{2}$ buffering capability of the metal-oxide pairs. For RRO buffer capsules, an aliquot of deionised water was added to the metal-oxide powder, while for the $\mathrm{NNO}$ mixture $\mathrm{H}_{2} \mathrm{O}$ was introduced via nickel-hydroxide. Finally, both single welded-shut inner

Table 1 Compositions of starting materials (in wt.\%)

\begin{tabular}{|c|c|c|c|c|c|c|c|c|c|c|c|c|c|c|}
\hline Starting material & $\mathrm{SiO}_{2}$ & $\mathrm{TiO}_{2}$ & $\mathrm{Al}_{2} \mathrm{O}_{3}$ & $\mathrm{Fe}_{2} \mathrm{O}_{3}$ & $\mathrm{FeO}$ & $\mathrm{MnO}$ & $\mathrm{MgO}$ & $\mathrm{CaO}$ & $\mathrm{Na}_{2} \mathrm{O}$ & $\mathrm{K}_{2} \mathrm{O}$ & $\mathrm{P}_{2} \mathrm{O}_{5}$ & $\mathrm{H}_{2} \mathrm{O}$ & $\mathrm{Fe}^{3+} / \mathrm{Fe}_{\text {tot }}{ }^{\mathrm{a}}$ & $\mathrm{xMg}^{\mathrm{b}}$ \\
\hline \multicolumn{15}{|l|}{ hot path } \\
\hline rk54 & 47.89 & 0.86 & 18.45 & 1.81 & 8.59 & 0.25 & 8.04 & 11.13 & 1.85 & 0.98 & 0.16 & 3.50 & 0.159 & 0.585 \\
\hline SM-FM81 & 48.00 & 0.92 & 19.34 & 1.86 & 8.57 & 0.26 & 6.90 & 10.98 & 1.96 & 1.04 & 0.17 & 3.73 & 0.163 & 0.547 \\
\hline SM-FM93 & 48.81 & 1.11 & 19.33 & 2.15 & 9.03 & 0.31 & 5.44 & 10.05 & 2.29 & 1.28 & 0.21 & 4.62 & 0.176 & 0.471 \\
\hline SM-FM129 & 50.31 & 0.98 & 19.07 & 2.55 & 9.45 & 0.35 & 4.24 & 8.85 & 2.46 & 1.46 & 0.26 & 5.58 & 0.195 & 0.393 \\
\hline \multicolumn{15}{|l|}{ hot oxidised path } \\
\hline SM-FM134 & 48.45 & 1.12 & 19.15 & 4.11 & 7.07 & 0.29 & 5.73 & 10.37 & 2.26 & 1.22 & 0.21 & 4.14 & 0.343 & 0.489 \\
\hline SM-FM143 & 50.82 & 1.11 & 19.30 & 4.10 & 6.35 & 0.33 & 4.45 & 9.04 & 2.80 & 1.46 & 0.24 & 5.07 & 0.367 & 0.443 \\
\hline \multicolumn{15}{|l|}{ hot rk52 path } \\
\hline rk52 & 47.49 & 0.76 & 17.60 & 1.74 & 8.09 & 0.22 & 9.50 & 12.06 & 1.63 & 0.79 & 0.13 & 2.96 & 0.162 & 0.638 \\
\hline SM-FM152 & 47.92 & 0.78 & 18.47 & 1.88 & 7.93 & 0.26 & 7.86 & 11.99 & 1.92 & 0.84 & 0.15 & 3.19 & 0.176 & 0.595 \\
\hline SM-FM157 & 48.42 & 0.81 & 19.30 & 2.18 & 8.46 & 0.30 & 5.94 & 10.96 & 2.37 & 1.06 & 0.19 & 4.08 & 0.188 & 0.506 \\
\hline \multicolumn{15}{|l|}{ intermediate path } \\
\hline SM-FM91 & 48.29 & 1.01 & 19.95 & 1.90 & 8.81 & 0.29 & 6.06 & 10.25 & 2.13 & 1.13 & 0.18 & 4.08 & 0.162 & 0.508 \\
\hline SM-FM112 & 49.18 & 1.20 & 19.64 & 2.14 & 8.96 & 0.33 & 5.05 & 9.64 & 2.34 & 1.31 & 0.21 & 4.73 & 0.177 & 0.454 \\
\hline SM-FM119 & 49.90 & 1.35 & 19.71 & 2.18 & 8.95 & 0.37 & 4.25 & 9.08 & 2.51 & 1.46 & 0.23 & 5.25 & 0.180 & 0.411 \\
\hline SM-FM128 & 52.47 & 1.17 & 19.30 & 2.48 & 9.05 & 0.46 & 2.86 & 7.48 & 2.69 & 1.75 & 0.30 & 6.62 & 0.198 & 0.313 \\
\hline SM-FM160 & 55.97 & 0.69 & 18.84 & 2.27 & 7.78 & 0.50 & 2.11 & 6.38 & 3.01 & 2.07 & 0.37 & 6.00 & 0.208 & 0.279 \\
\hline \multicolumn{15}{|l|}{ cold path } \\
\hline SM-FM98 & 50.19 & 1.14 & 19.81 & 1.96 & 9.20 & 0.32 & 4.65 & 8.63 & 2.55 & 1.32 & 0.23 & 5.09 & 0.161 & 0.432 \\
\hline SM-FM106 & 50.97 & 1.28 & 19.50 & 2.18 & 9.28 & 0.34 & 4.16 & 7.85 & 2.72 & 1.46 & 0.25 & 5.62 & 0.175 & 0.399 \\
\hline SM-FM116 & 52.43 & 1.33 & 19.58 & 2.12 & 8.73 & 0.36 & 3.37 & 7.19 & 2.96 & 1.63 & 0.28 & 6.33 & 0.180 & 0.362 \\
\hline SM-FM121 & 60.72 & 0.86 & 19.48 & 1.04 & 3.46 & 0.33 & 2.31 & 5.54 & 3.63 & 2.23 & 0.39 & 8.83 & 0.213 & 0.486 \\
\hline
\end{tabular}

${ }^{\text {a }}$ Ratio of ferric to total iron $\left(=\mathrm{Fe}^{3+} /\left(\mathrm{Fe}^{3+}+\mathrm{Fe}^{2+}\right)\right)$ at $\mathrm{NNO}$ (or RRO) calculated for experimental run conditions using the algorithm of Kress and Carmichael (1991)

${ }^{\mathrm{b}} \mathrm{xMg}=\mathrm{MgO} /(\mathrm{MgO}+\mathrm{FeO})$, molar ratio, all iron treated as $\mathrm{Fe}^{2+}$ 
capsules plus the same experimental starting material acting as spacer material were placed in the outer capsule (made of the same noble metal as the inner experimental capsule), which was subsequently closed by arc welding.

\section{Experimental procedure}

Experiments at 1.0, 0.8, and 0.6 GPa were run in an endloaded 14-mm bore Boyd and England-type piston cylinder apparatus at ETH Zürich. NaCl-Pyrex-graphite-MgO assemblies were utilised, and a friction correction of 5\% was applied to the nominal pressure. Capsules were placed in the hotspot of the assembly, whose position was estimated using the numerical algorithm of Hernlund et al. (2006). Temperature was measured with a B-type thermocouple $\left(\mathrm{Pt}_{94} \mathrm{Rh}_{6} /\right.$ $\mathrm{Pt}_{70} \mathrm{Rh}_{30}$ ) with an estimated accuracy of $\pm 10^{\circ} \mathrm{C}$. No correction for the pressure effect on the electromotive force (e.m.f.) was applied. Numerical modelling revealed that hotspot temperatures were $7-16^{\circ} \mathrm{C}$ higher than the effective thermocouple reading. Oil pressure was automatically controlled with an in-house built worm-gear-type pressure control system with a tolerance window of 0.5 bar oil pressure $(\approx 40 \mathrm{MPa})$. After capsule loading, assemblies were initially pressurised to approximately 50 bar oil pressure $(\approx 0.4 \mathrm{GPa})$ at ambient temperature and then heated with a continuous rate of $40{ }^{\circ} \mathrm{C} /$ min to final run temperatures. Pressure was slowly increased when temperature exceeded $500{ }^{\circ} \mathrm{C}$ (softening point of Pyrex glass), but care was taken to reach final pressure before the attainment of the run temperature. Experimental run times varied from 6 to $73 \mathrm{~h}$ with longer durations at lower temperatures. Finally, experiments were quenched by switching off the power supply resulting in cooling rates exceeding $100{ }^{\circ} \mathrm{C} / \mathrm{s}$.

Experiments at $0.4 \mathrm{GPa}$ were performed in a $22-\mathrm{mm}$ bore non-end-loaded Johannes-type piston cylinder at ETH Zürich, which was specifically calibrated for low-pressure conditions employing the $\mathrm{NaCl}$ melting curve (Clark 1959) in combination with the falling sphere technique (e.g. Baker 2004). Run protocol and control of pressure and temperature were identical to experiments run at higher pressures in the 14-mm bore Boyd and England-type piston cylinder, with the exception that a slightly different $\mathrm{NaCl}-\mathrm{Pyrex}$-graphite- $\mathrm{MgO}$ assembly was utilised (see Electronic Supplementary Material ESM 2). Thereby, capsules were additionally embedded in Pyrex glass powder to ensure homogenous pressure distribution. After loading, experiments were pressurised to approximately $0.15 \mathrm{GPa}$, and subsequent heating procedure was identical to the end-loaded piston cylinder approach. Cooling rates during quenching were slightly lower $\left(50-100^{\circ} \mathrm{C} / \mathrm{s}\right)$ compared to the $14-\mathrm{mm}$ assembly used for the experiments at higher pressures due to the larger volume of the 22-mm assembly.
Experiments at $0.2 \mathrm{GPa}$ were run in externally heated Molybdenum-Hafnium-Carbide (MHC) pressure vessels at ETH Zürich. A gas mixture of $\mathrm{Ar}-\mathrm{CH}_{4}$ was used as pressurising medium, where methane acted as a reactant component buffering hydrogen fugacity and, thus, $\mathrm{fO}_{2}$ in the run charges. Methane contents of the gas mixture were adjusted to maintain $\mathrm{fO}_{2}$ conditions close to the $\mathrm{NNO}$ or RRO buffer. General run procedure was as follows: after capsule loading, vessels were first filled with appropriate amounts of methane and subsequently pressurised with argon to levels corresponding to roughly half of the final run pressure. Then heating was started, and gas pressure increased simultaneously with temperature due to thermal expansion. After run temperature was reached, pressure was adjusted manually to the final target level of $200 \mathrm{MPa}$. During experiments, pressure was monitored using a pressure sensor with an uncertainty of $0.5 \%$ and manually controlled at $200 \mathrm{MPa}$ with a maximum deviation of $\pm 2 \mathrm{MPa}$. Temperature was controlled with a K-type thermocouple, which was positioned outside of the MHC vessel above the approximate capsule position. Temperature recorded with this external thermocouple was calibrated against effective experimental temperature inside the bomb every time a new vessel was installed. Generally, internal and external temperature readings exhibit a linear relationship, and $2 \sigma$ errors on established temperature calibrations were below $10{ }^{\circ} \mathrm{C}$. During experiments, vessels were oriented with an inclination of $10^{\circ}$ to ensure the development of a stable temperature profile. All experiments run in the MHC pressure vessels were equilibrated at run conditions for $72 \mathrm{~h}$. Quenching was attained by tilting the furnace by $90^{\circ}$ into a vertical position forcing the capsule to fall to the cold end of the vessel, resulting in quenching rates exceeding $100^{\circ} \mathrm{C} / \mathrm{s}$. For one experiment (FM146), temperature cycling (e.g. Mills and Glazner 2013) was performed to promote the formation of melt pools large enough for reliable analysis. Thereby, temperature was cycled with $\pm 10{ }^{\circ} \mathrm{C}$ around the target equilibrium temperature $\left(960^{\circ} \mathrm{C}\right)$ for half of the intended run duration. Employed heating and cooling rates during temperature cycling were $0.5{ }^{\circ} \mathrm{C} / \mathrm{min}$ and temperature plateaus were hold for $40 \mathrm{~min}$. After this initial cycling phase, temperature was adjusted to $960{ }^{\circ} \mathrm{C}$ and kept for the remaining time of the experiment.

\section{Sample preparation and analytical techniques}

Recovered capsules were embedded in epoxy-resin, opened with grinding paper to expose a longitudinal cross section, and subsequently polished using diamond suspensions with finest grades of $1 \mu \mathrm{m}$. Polished charges were inspected under an optical microscope for capsule coherence and any peculiar textures. In addition, buffer capsules were checked for the presence of metal and oxide phases to verify the $\mathrm{fO}_{2}$ buffering capability of the buffer assemblage mixture 
throughout the entire run duration. Subsequently, specimens were coated with $20 \mathrm{~nm}$ of carbon and analysed with a JEOL JSM-6390 Scanning Electron Microscope at ETH Zürich. Runs were checked for general appearance, and high-quality back-scatter electron (BSE) images were acquired. First quantitative compositional data of glasses and minerals were obtained with a standardised Thermo Fisher NORAN NSS7 Energy-Dispersive Spectroscopic system with a $30 \mathrm{~mm}^{2}$ Silicon-drift detector (SDD) (SEM-EDS). Acceleration voltage for imaging and measurements was set to $15 \mathrm{kV}$. In a final step, major phases (glass, olivine, hercynitic spinel, plagioclase, ortho- and clinopyroxene, amphibole, biotite, magnetite, ilmenite, and apatite) were analysed with two JEOL Electron Probe Micro Analysers (EPMA) at ETH Zürich. Approximately half of the experiments presented in this project were measured with a JEOL JXA 8200 Superprobe, while a JEOL JXA 8230 Superprobe was used for the second half. The same set of oxide and silicate standards was utilised for both devices, and a comparison of analytical results revealed no significant differences. An acceleration voltage of $15 \mathrm{kV}$ was utilised for analysis. Sodium and potassium were measured first to avoid extensive alkali migration. Hydrous glasses were analysed with a beam current of $7 \mathrm{nA}$ and a beam diameter of $20 \mu \mathrm{m}$. In case residual melt pools were too small, beam currents were reduced to 4 or $2 \mathrm{nA}$ and spot sizes to 10 or $5 \mu \mathrm{m}$. Plagioclase, biotite, and apatite were analysed with a focussed beam and a current of $10 \mathrm{nA}$, while the other phases (pyroxenes, amphibole, olivine, spinel, magnetite, and ilmenite) were measured with a focussed beam and a current of $20 \mathrm{nA}$. For $\mathrm{fO}_{2}$ reconstruction, iron contents of AuPd capsule material pieces were measured with a beam current of $20 \mathrm{nA}$ and pure metal standards for $\mathrm{Au}$ and $\mathrm{Pd}$ and wustite for Fe.

\section{Results}

An overview of experimental run conditions is given in Table 2, including employed starting materials, capsule materials, stable phase assemblages, phase proportions, relative Fe-losses, estimated melt water contents, and calculated minimum $\mathrm{fO}_{2}$ conditions based on water activity. These data are also supplied in an electronic form in the Electronic Supplementary Material ESM 3.

\section{General remarks}

All successful experiments consisted of residual liquid quenched to a homogenous glass and a variety of mineral phases, namely, olivine (ol), clinopyroxene (cpx), orthopyroxene (opx), plagioclase (plag), hercynitic spinel (sp), amphibole (amph), magnetite (mt), biotite (bt), ilmenite (ilm), and apatite (ap). Although most experiments were nominally $\mathrm{H}_{2} \mathrm{O}$-undersaturated, fluid bubbles were observed in all runs, indicating that fluid-saturated conditions were met. Pure $\mathrm{H}_{2} \mathrm{O}$-saturation was reached by a few experiments performed at low temperatures $\left(<1000{ }^{\circ} \mathrm{C}\right)$ and low pressures $(0.2$ or $0.4 \mathrm{GPa}$, compare Table 2$)$. The occurrence of a free fluid phase in the $\mathrm{H}_{2} \mathrm{O}$-undersaturated experiments is most probably the consequence of the presence of additional fluid components in the charges with low solubilities in silicate liquids. One likely candidate is $\mathrm{CO}_{2}$ which was introduced via absorption by the fine-grained synthetic starting material powders (Ulmer et al. 2018). Although starting materials were stored at $110^{\circ} \mathrm{C}$ before capsule loading and attention was paid to process new starting materials quickly after synthesis, the presence of $\mathrm{CO}_{2}$ in the final charge could not be avoided. A further likely contaminant fluid component is $\mathrm{N}_{2}$ that was incorporated from the surrounding air during capsule preparation. However, results from a crosscheck experiment on a pre-vitrified starting material $( \pm$ free of $\mathrm{CO}_{2}$ and $\mathrm{N}_{2}$ ) infer that the presence of small amounts of these additional volatile compounds had no discernible impact on phase equilibria and compositions of residual melts and coexisting minerals (Marxer 2021).

A prerequisite for successful experimentation is the maintenance of a chemically closed system. Two compounds that potentially escape and/or contaminate the experimental charge at run conditions are iron and hydrogen. We quantified iron loss for each run via mass balance regression, treating all iron alloying with the capsule as an additional phase for calculations. In addition, for runs containing an $\mathrm{Fe}-\mathrm{Ti}$-oxide phase (complicating mass balance calculations), proportions of ilmenite or magnetite were independently determined via image processing on BSE images of entire charges employing the software ImageJ. First, the capsule material as well all voids and cracks were manually removed via blackening. Subsequently, oxide proportions were estimated assuming that area fractions equal volume fractions. Finally, volume proportions were converted to mass fractions employing calculated densities of all coexisting phases. Densities of residual melts were established using the algorithm of Lange and Carmichael (1987), while densities of mineral phases were derived employing a Birch-Murnaghan equation of state and an own compilation of required thermodynamic parameters. Fe-losses were finally recalculated via mass balance employing oxide fractions obtained by image processing. For two experiments (FM146 and FM121), established iron losses were negative indicative of iron gain, illustrating the general drawback of image analysis procedures as the underlying assumption of homogeneous distribution of oxide phases in the experimental charge is most probably not entirely correct. Magnetite tends to preferentially nucleate on capsule walls, and previous studies reported accumulation of magnetite crystals on volatile bubbles by floating (e.g. Knipping et al. 2019). 


\begin{tabular}{|c|c|c|c|c|c|c|c|c|c|c|c|c|}
\hline 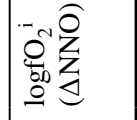 & 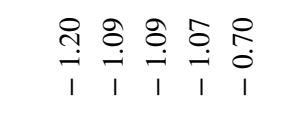 & \begin{tabular}{ll}
\multirow{2}{*}{} & 0 \\
0 & 0 \\
0 & 0 \\
1 & 1
\end{tabular} & 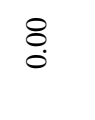 & $\stackrel{M}{=}$ & $\stackrel{\infty}{\underset{-}{-}}$ & $\bar{a}$ & 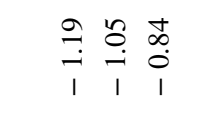 & $\begin{array}{c}\hat{\sigma} \\
i \\
1\end{array}$ & $\underset{\stackrel{8}{+}}{1}$ & $\begin{array}{ll}R & 8 \\
0 & 0 \\
i & 1 \\
1 & 1\end{array}$ & 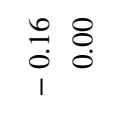 & $\stackrel{8}{0}$ \\
\hline & 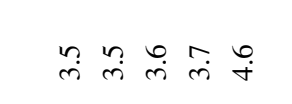 & $\stackrel{0}{\circ} \stackrel{0}{+}$ & $\begin{array}{l}\infty \\
\infty \\
i\end{array}$ & $\stackrel{+}{+}$ & $\vec{n}$ & 空 & 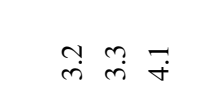 & n' & $\bar{F}$ & 于̛ & $\vec{\infty} \vec{\infty}$ & : \\
\hline 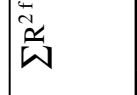 & $\begin{array}{l}n \\
\\
0\end{array}$ & $\stackrel{t}{0}$ & $\stackrel{d}{0}$ & $\overline{0}$ & $\overrightarrow{\dot{\sigma}}$ & $\stackrel{0}{0}$ & $\stackrel{0}{0}$ & $\stackrel{\infty}{0}$ & $\overrightarrow{0}$ & $\stackrel{ \pm}{0}$ & $\stackrel{0}{0}$ & $\overline{0}$ \\
\hline 总 & 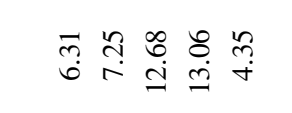 & $\begin{array}{ll}\hat{\hat{\theta}} & \hat{0} \\
\hat{\theta} & \infty\end{array}$ & 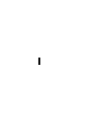 & $\stackrel{a}{i}$ & $\underset{\substack{+i}}{i}$ & $\stackrel{\hat{\vartheta}}{6}$ & 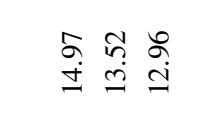 & $\stackrel{n}{\stackrel{m}{9}}$ & 年 & $\stackrel{\infty}{\stackrel{\circ}{\ominus}} \stackrel{m}{+}$ & 号 & $\stackrel{i}{i}$ \\
\hline 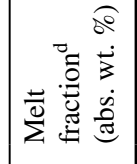 & 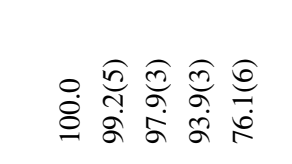 & 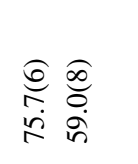 & $\frac{\sqrt{n}}{\mathfrak{n}}$ & 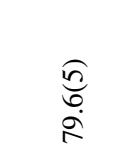 & $\frac{6}{6}$ & 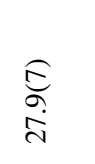 & 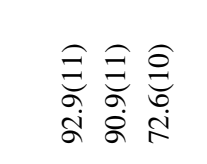 & $\begin{array}{l}\widehat{m} \\
\stackrel{0}{0} \\
\dot{\leftrightarrow n}\end{array}$ & $\begin{array}{c}\sqrt[n]{c} \\
\substack{\infty \\
\infty} \\
\infty\end{array}$ & 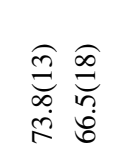 & 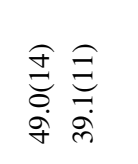 & 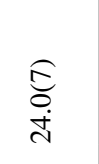 \\
\hline 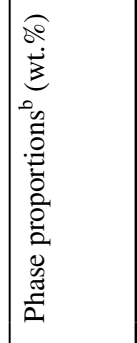 & 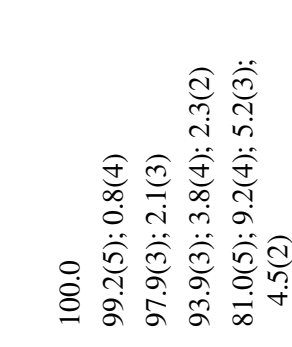 & 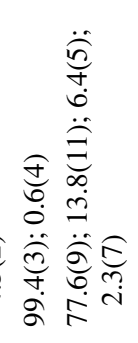 & 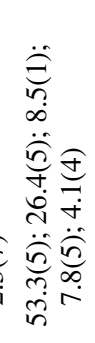 & 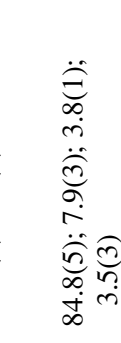 & 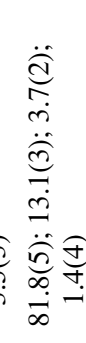 & 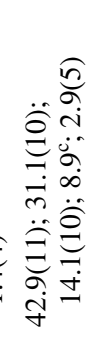 & 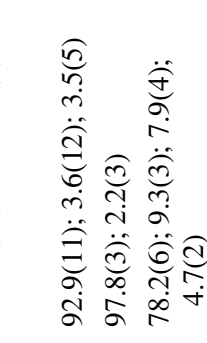 & 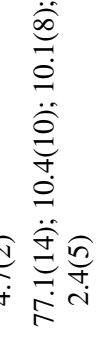 & 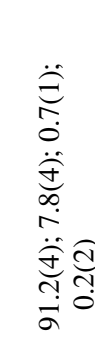 & 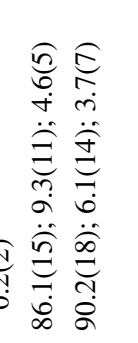 & 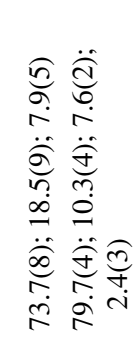 & 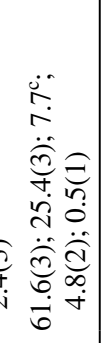 \\
\hline 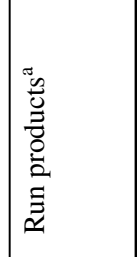 & 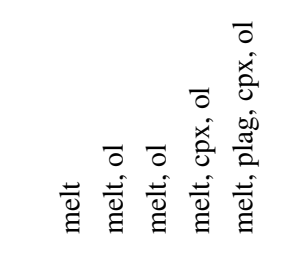 & 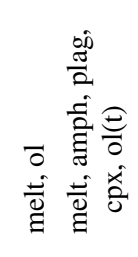 & 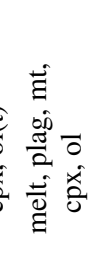 & 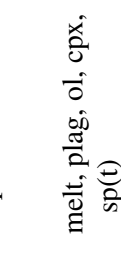 & 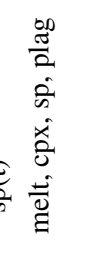 & 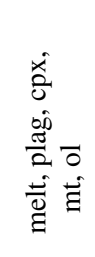 & 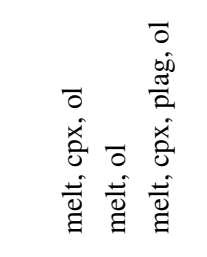 & 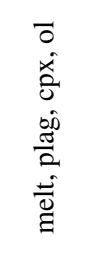 & 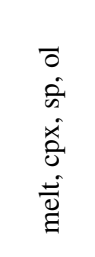 & 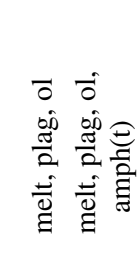 & 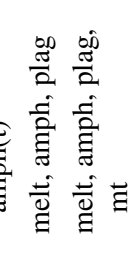 & 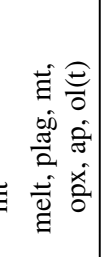 \\
\hline 吾 & 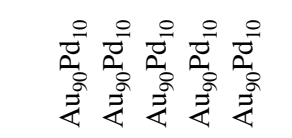 & 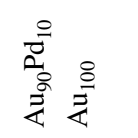 & $\stackrel{8}{\underline{3}}$ & 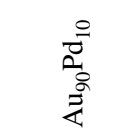 & 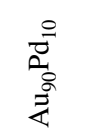 & $\stackrel{8}{\frac{8}{4}}$ & 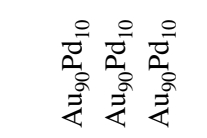 & $\stackrel{\circ}{\frac{8}{4}}$ & 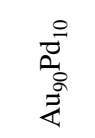 & 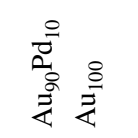 & 曾竞 & $\stackrel{8}{\underline{\underline{z}}}$ \\
\hline 递 & 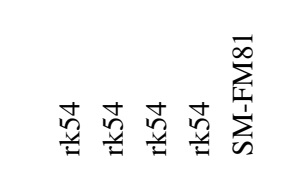 & $\sum_{\substack{i=\\
i}}^{\infty} \sum_{i=1}^{\infty}$ & 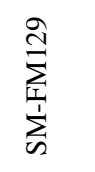 & 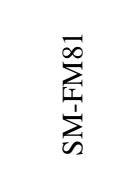 & $\underset{\substack{+\sum_{i=1}^{+}}}{\stackrel{N}{+}}$ & $\underset{\sum_{n=1}^{+}}{\stackrel{P}{=}}$ & 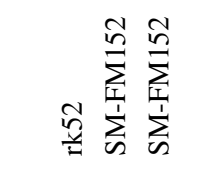 & $\sum_{i=1}^{n}$ & 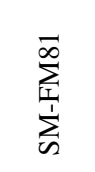 & 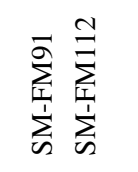 & $\underset{\sum}{\sum_{i=1}} \sum_{i=1}^{\infty}$ & $\sum_{\substack{1 \\
i=1}}^{\infty}$ \\
\hline હ & 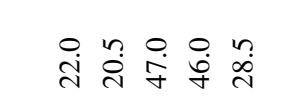 & 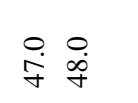 & $\stackrel{\circ}{i}$ & $\underset{\infty}{\infty}$ & $\underset{\dot{\infty}}{\stackrel{+}{\sigma}}$ & $\stackrel{\circ}{i}$ & ن용 & $\stackrel{\circ}{\circ}$ & $\begin{array}{l}\stackrel{0}{+} \\
\dot{q}\end{array}$ & $\begin{array}{cc}0 & 0 \\
\dot{d} & \stackrel{\infty}{q}\end{array}$ & $\stackrel{i}{i} \stackrel{\text { i }}{i}$ & $\ddot{8}$ \\
\hline & 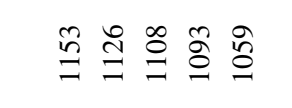 & $\overrightarrow{\underline{\rho}} \overline{\underline{\sigma}}$ & \&ু & $\stackrel{8}{\circ}$ & $\stackrel{\tilde{O}}{\varrho}$ & \&ু & 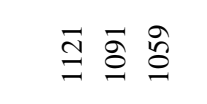 & $\stackrel{\tilde{\Xi}}{\Theta}$ & $\stackrel{\circ}{\stackrel{o}{\varrho}}$ & $\stackrel{\infty}{\stackrel{\circ}{g}} \stackrel{\infty}{\sigma}$ & 종영 & \&ু \\
\hline & $\stackrel{q}{g} \stackrel{ }{g} \stackrel{\circ}{g}$ & ๕్ \& & \&ু & $\stackrel{8}{9}$ & ฮ్రి & \& & $\stackrel{\circ}{g} \stackrel{\circ}{9}$ & ฮิ & $\stackrel{\circ}{\circ}$ & ฮิ & \& & \&ু \\
\hline 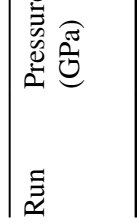 & 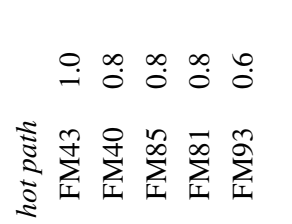 & 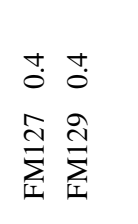 & 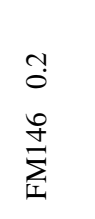 & 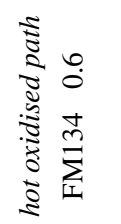 & $\begin{array}{l}\stackrel{+}{0} \\
\stackrel{9}{*} \\
\sum_{i}^{*}\end{array}$ & $\begin{array}{l}3 \\
0 \\
0 \\
\sum^{n}\end{array}$ & 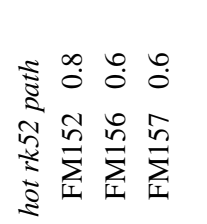 & $\begin{array}{l}+ \\
0 \\
0 \\
0 \\
\sum_{i}^{1}\end{array}$ & 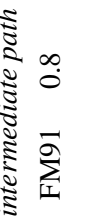 & 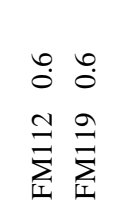 & 至 & $\begin{array}{l}0 \\
+ \\
=\end{array}$ \\
\hline
\end{tabular}




\begin{tabular}{|c|c|c|c|c|c|c|c|c|c|}
\hline 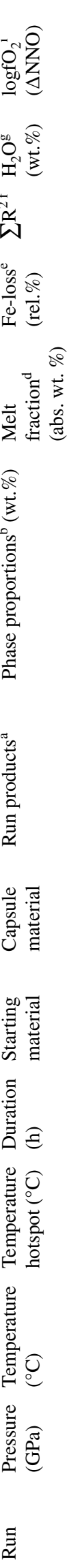 & 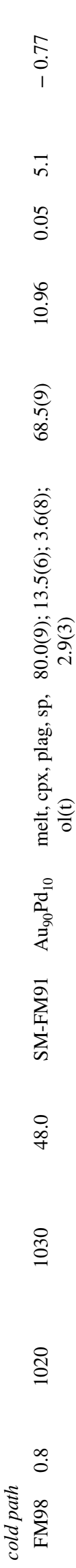 & 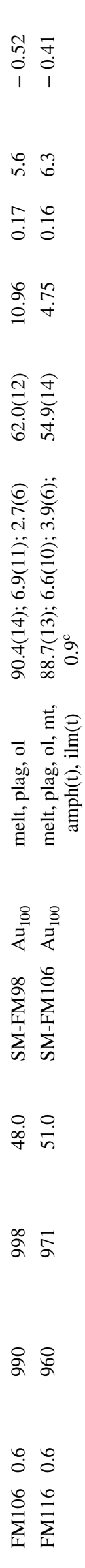 & 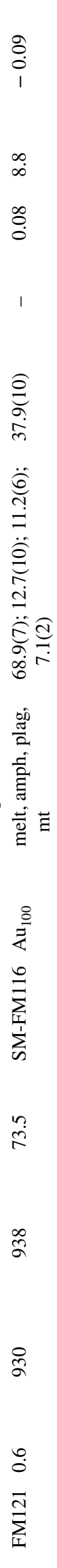 & 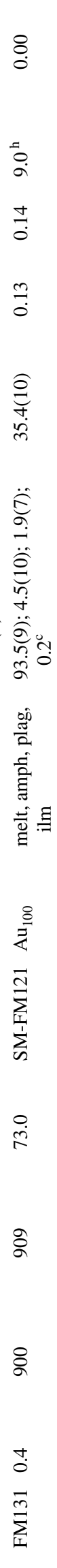 & 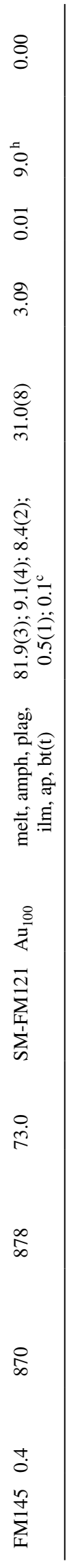 & 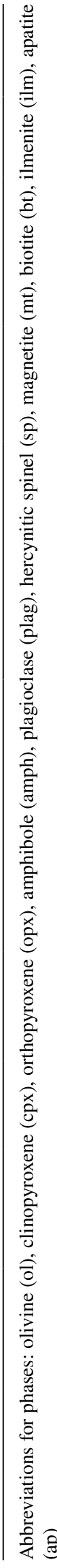 & 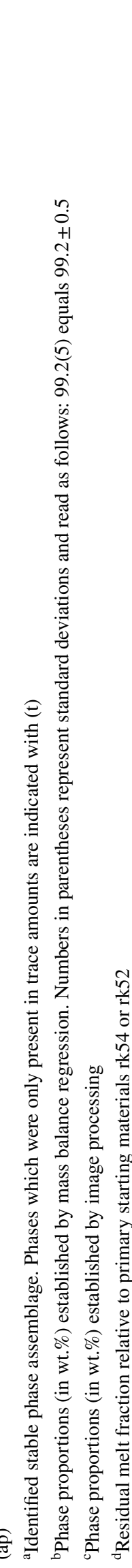 & 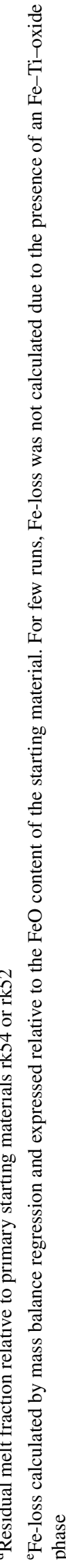 & 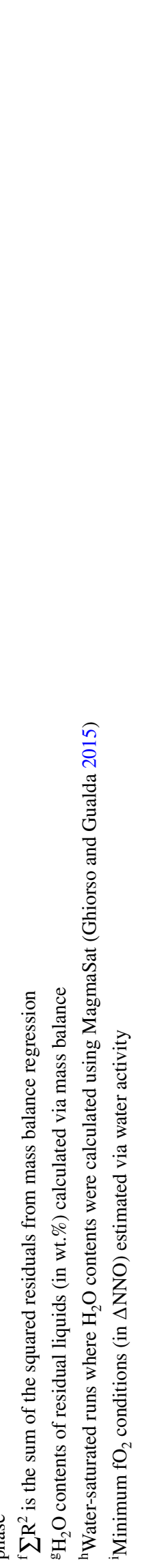 \\
\hline
\end{tabular}


Accounting for this uncertainty by assuming a relative error of $20 \%$ on $\mathrm{Fe}-\mathrm{Ti}$-oxide fractions results in maximum estimated $\mathrm{Fe}$-loss close to zero. Consequently, we assumed that Fe-loss was negligible for these runs and report $\mathrm{Fe}-\mathrm{Ti}$-oxide proportions estimated via mass balance (Table 2). This is consistent with the relatively low temperatures of these runs $\left(<1000{ }^{\circ} \mathrm{C}\right)$ and the use of pure Au capsules, representing well-known experimental conditions to minimise iron loss (e.g. Barr and Grove 2010).

Generally, established Fe-losses were below 15.5\% (relative to the $\mathrm{FeO}$ content of the employed starting material) for all fractionation experiments. However, especially for runs performed at high temperatures $\left(\geq 1020{ }^{\circ} \mathrm{C}\right)$ in $\mathrm{Au}_{90} \mathrm{Pd}_{10}$ capsules, loss of iron was significant due to an increasing maximum solubility of iron in AuPd alloys with increasing temperature and palladium content (Barr and Grove 2010). Furthermore, noble metal capsules are permeable for hydrogen under experimental $\mathrm{P}-\mathrm{T}$ conditions leading to either $\mathrm{H}$-gain or $\mathrm{H}$-loss via diffusion during run conduction (e.g. Eugster 1957; Eugster and Wones 1962). The solid buffer assemblage (NNO or RRO) imposes an intrinsic hydrogen fugacity $\left(\mathrm{fH}_{2}\right)$ which equilibrates throughout the entire outer capsule thereby constraining a specific $\mathrm{fO}_{2}$ in the second inner capsule containing the experimental charge. Consequently, hydrogen loss is expected to be negligible for this study as long as the solid-state buffer was capable of maintaining a roughly constant $\mathrm{fH}_{2}$ throughout the entire outer capsule. Generally, Fe-loss to the inner capsule results in the formation of free oxygen which either oxidises ferrous iron to ferric iron or reacts with the hydrogen supplied from the $\mathrm{fO}_{2}$ buffer to $\mathrm{H}_{2} \mathrm{O}$. Consequently, pronounced iron loss can lead to an increase of water contents of experimental charges as long as $\mathrm{fH}_{2}$ is buffered. However, we infer that due to the elevated water contents of the employed starting materials of this study ( $>3.5 \mathrm{wt} . \%$ ) the amount of additional $\mathrm{H}_{2} \mathrm{O}$ formed is generally negligible, since the highest estimated iron loss (15.5\%) could only have supplied a maximum of $0.35 \mathrm{wt} . \%$ of additional water.

Water contents of residual melts were quantified for few selected runs via Raman spectroscopy. Analytical procedures and results are presented in the Electronic Supplementary Material ESM 2. However, consistent phase assemblages and chemical trends of experimental runs indicate that $\mathrm{H}_{2} \mathrm{O}$ contents evolve systematically along the LLD as inferred by mass balance considerations. This is supported by a continuous increase of glass water contents estimated via the EPMA "by-difference" method (e.g. Anderson 1973; Blundy and Cashman 2008; Hughes et al. 2019) with decreasing temperature. However, $\mathrm{H}_{2} \mathrm{O}$ contents established via the "by-difference" approach are approximately $2 \mathrm{wt}$.\% higher compared to mass balance calculations, which we assign to a matrix effect during EPMA analysis due to the standardisation on mineral phases. For experiments containing plagioclase we utilised the Waters and Lange (2015) plagioclase-melt hygrometer to calculate melt water contents that match mass balance results at concentrations below $6.0 \mathrm{wt} . \%$ $\mathrm{H}_{2} \mathrm{O}$ to within $10 \%$. At higher nominal $\mathrm{H}_{2} \mathrm{O}$ contents, this disparity increases to $1.0-3.0 \mathrm{wt} . \%$ pointing towards limitations of the Waters and Lange (2015) algorithm at elevated melt water contents (and pressures).

\section{Oxygen fugacity}

Most runs were $\mathrm{H}_{2} \mathrm{O}$-undersaturated and, thus, the $\mathrm{fO}_{2}$ conditions in the run capsules were displaced to lower values compared to the nominal buffer equilibria (NNO or RRO) by the factor $2 * \log \left(\mathrm{aH}_{2} \mathrm{O}\right.$ ) (where $\mathrm{aH}_{2} \mathrm{O}$ corresponds to the activity of water in the experimental charge). Only, when experimental runs reached water-saturation $\left(\mathrm{aH}_{2} \mathrm{O}=1\right)$, which was the case for some low-temperature and lowpressure runs, buffered redox conditions corresponded to $\mathrm{NNO}$ or RRO. Consequently, we estimated minimum $\mathrm{fO}_{2}$ of our experiments employing the Burnham water solubility and activity model (e.g. Burnham and Davis 1974; Burnham 1994) following the procedure described in Holloway and Blank (1994). For each run, water contents of recovered residual glasses were calculated via mass balance using mineral phase proportions and $\mathrm{H}_{2} \mathrm{O}$ concentrations of employed starting materials. Water activities were subsequently calculated employing the Burnham algorithm. Melt compositional parameters and derived water activities are summarised in the Electronic Supplementary Material ESM 4. However, the Burnham algorithm tends to underestimate $\mathrm{H}_{2} \mathrm{O}$ solubility at higher pressures (e.g. Holtz et al. 1995; Botcharnikov et al. 2005) resulting in a slight overestimation of $\mathrm{aH}_{2} \mathrm{O}$. The water activities were then used to estimate experimental redox conditions. Calculated $\mathrm{fO}_{2}$ values are reported relative to NNO (Table 2). They represent minimum conditions since failure of the inner buffer capsule would result in a slight increase in $\mathrm{fO}_{2}$.

The attainment of targeted experimental redox conditions was verified with several different, independent approaches. Figure 2 summarises $\mathrm{fO}_{2}$ conditions expressed relative to the NNO equilibrium. For a limited number of experiments, $\mathrm{fO}_{2}$ conditions were reconstructed via the solubility of $\mathrm{Fe}$ in AuPd alloys employing the solution model of Barr and Grove (2010). For this purpose, iron contents of small noble metal pieces $\left(\mathrm{Au}_{90} \mathrm{Pd}_{10}\right)$ dispersed in the experimental charges were measured by EPMA. For some runs, a rather large variability of alloy compositions (and resultant redox conditions) was observed. Therefore, we only report ranges of reconstructed $\mathrm{fO}_{2}$. The lowest $\mathrm{fO}_{2}$ corresponds to the highest measured iron content, and vice versa. The large spread of AuPdFe compositions is mainly related to the uncertainty on the attainment of equilibrium between silicate melt and noble capsule 


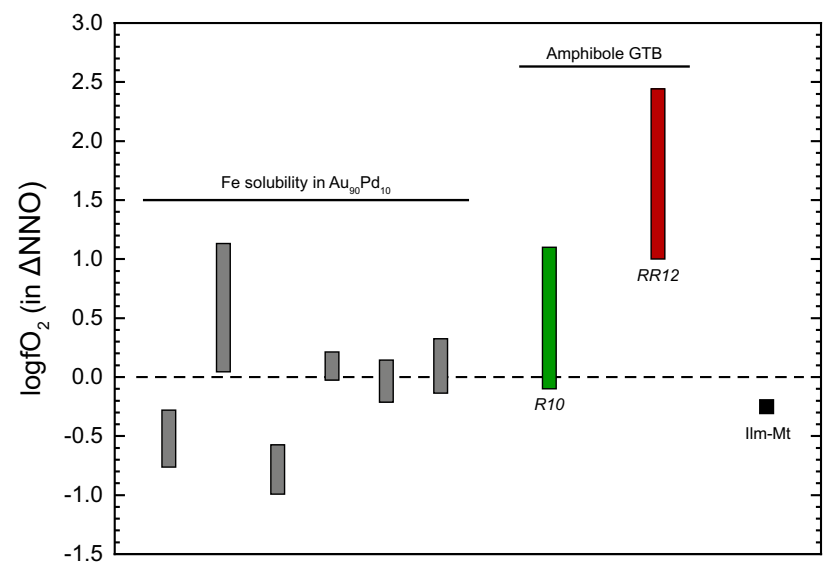

Fig. 2 Range of experimental $\mathrm{fO}_{2}$ conditions estimated via the solubility of $\mathrm{Fe}$ in $\mathrm{Au}_{90} \mathrm{Pd}_{10}$, amphibole geothermobarometry (GTB) employing the algorithms of Ridolfi et al. (2010) (R10) and Ridolfi and Renzulli (2012) (RR12), and ilmenite-magnetite oxybarometry (Ilm-Mt). For more details on calculation procedures, see text

metal. Consequently, we infer that the lower ends of the $\mathrm{fO}_{2}$ range represent the most realistic values for experimental $\mathrm{fO}_{2}$ conditions. In general, $\mathrm{fO}_{2}$ conditions vary between NNO-1 and NNO+1 with a majority plotting in a narrower range of $\mathrm{NNO}_{ \pm} 0.5$. When only considering minimum values, the range of $\mathrm{fO}_{2}$ conditions narrows to NNO-1 to NNO, in agreement with minimum redox conditions of experimental charges inferred from water activities and redox buffers (Table 2). Measured alloy compositions, calculated $\mathrm{fO}_{2}$ conditions, and estimated errors are reported in the Electronic Supplementary Material ESM 5. In addition, experimental $\mathrm{fO}_{2}$ conditions were estimated for amphibole-bearing charges employing the thermobarometric algorithms of Ridolfi et al. (2010) (R10) and Ridolfi and Renzulli (2012) (RR12). The R10 model results in consistently lower $\mathrm{fO}_{2}$ than the RR12 model. Results from the R10 formulation vary between NNO-0.1 and $\mathrm{NNO}+1.1$, while values calculated with RR12 range from $\mathrm{NNO}+1.0$ to NNO+2.4. No consistent trends of calculated $\mathrm{fO}_{2}$ with experimental temperature or pressure were observed and, thus, only ranges of established $\mathrm{fO}_{2}$ are reported (Fig. 2). In agreement with Erdmann et al. (2014), we infer that the RR12 algorithm tends to overestimate $\mathrm{fO}_{2}$ conditions and conclude that redox conditions determined with the R10 model are more realistic. Finally, in one experiment (FM116, $960{ }^{\circ} \mathrm{C}$ and $0.6 \mathrm{GPa}$ ), magnetite and ilmenite coexist and, thus, Fe-Ti-oxide oxybarometry was applied. The algorithm of Ghiorso and Evans (2008) resulted an $\mathrm{Fe}-\mathrm{Ti}$ exchange temperature of $954{ }^{\circ} \mathrm{C}$ and a $\operatorname{logfO}{ }_{2}$ of NNO-0.25. Both values agree within error with experimental conditions, confirming that the experiments were buffered at redox conditions close to NNO.

\section{Run appearance}

The step-wise experimental approach to fractional crystallisation generated high residual melt fractions exceeding 40-50 wt.\% (in most cases $>70 \mathrm{wt} . \%$ ) facilitating the analysis of hydrous glasses. For most experiments, mineral phases were homogeneously distributed over exposed capsule sections. In few cases, weak gradients in phase abundances (e.g. zones with higher melt fractions) were observed and attributed to small temperature gradients $\left(<10{ }^{\circ} \mathrm{C}\right.$ over the length of entire outer capsules). Additionally, glasses and mineral phases were analysed throughout, and no systematic compositional variations were observed. The employment of different experimental techniques and apparatus for the polybaric fractionation approach resulted in a distinct textural variability of recovered charges, which is described in detail in the following paragraphs and illustrated in Fig. 3.

In general, the formation of quench phases (e.g. plagioclase, clinopyroxene, amphibole, or biotite) was of minor extent in runs performed in the 14-mm Boyd and Englandtype piston cylinder ( 0.8 and $0.6 \mathrm{GPa}$ ), slightly more extensive in the experiments run in the 22-mm non-end-loaded Johannes-type piston cylinder (due to the slower quenching rates), and completely absent for experiments conducted at $0.2 \mathrm{GPa}$ in the MHC pressure vessels. Quench crystallisation was either observed as overgrowth rims on stable mineral phases (e.g. high-albite plagioclase rims or clinopyroxene/amphibole overgrowth on equilibrium clinopyroxene) or direct nucleation of new crystals from the groundmass glass (biotite laths). Relics of unreacted starting material are almost entirely absent except in run FM164 where $\mathrm{Al}_{2} \mathrm{O}_{3}$ relics were identified as small inclusions in plagioclase clusters. Olivine was equant and often exhibited rounded shapes (Fig. 3a, b and e), which we interpret as a result of crystallisation kinetics of olivine in magmatic experiments, where olivine generally tends to crystallise extensively during the initial phase of an experiment, while the nucleation and growth of other phases are retarded. As soon as coexisting stable mineral phases start crystallising, olivine composition and modal abundance re-adapt to changing melt composition via partial resorption to approach final equilibrium. Clinopyroxene was mostly small and equant $(<10 \mu \mathrm{m})$ and sometimes exhibited bright cores with low $\mathrm{Al}$ contents, which we interpret as metastable cores formed during nucleation (Fig. 3a). Therefore, care was taken to avoid such cores during EPMA analysis. Extending run duration resulted in successful reduction of the abundance of these low-Al cores. In two experiments (FM93 and FM146) sector zoned clinopyroxenes (Fig. 3f), were identified, a feature that has previously been reported in experimental studies (e.g. Sisson and Grove 1993a; Ulmer et al. 2018) and natural rocks (e.g. Hurlimann et al. 2016). We infer that the formation of sector zoning is a result of rapid crystal growth close to the 

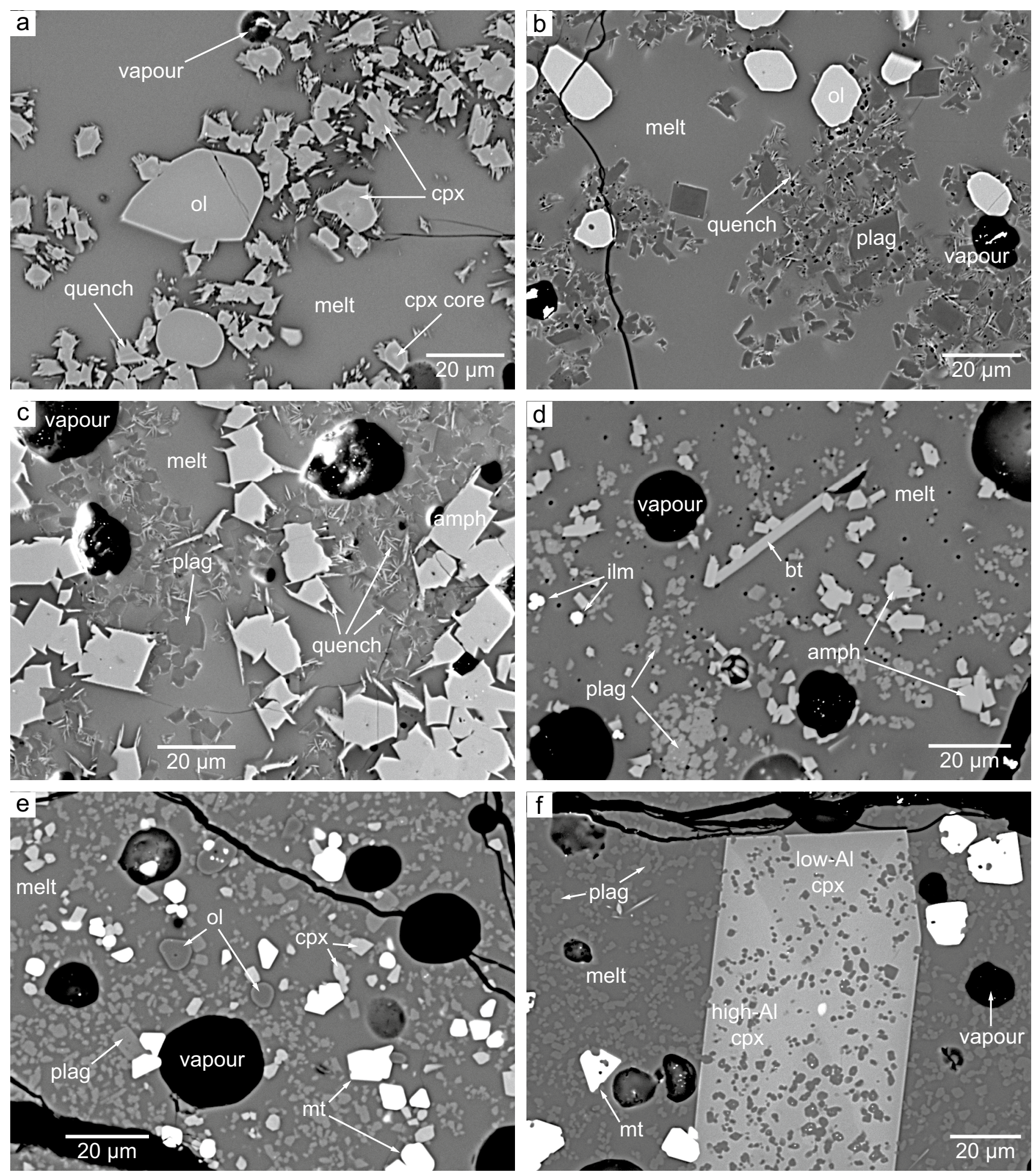

Fig. 3 Representative BSE images of experimental charges. Phase abbreviations are: olivine (ol), clinopyroxene (cpx), plagioclase (plag), amphibole (amph), magnetite (mt), ilmenite (ilm), and biotite (bt). a FM91 $\left(1050{ }^{\circ} \mathrm{C}\right.$ and $\left.0.8 \mathrm{GPa}\right)$ with metastable low-Al cores

upper stability limit of clinopyroxene favouring crystallisation over nucleation (Schwandt and Mckay 2006). For run FM146, clinopyroxene sector zoning was likely promoted by

in cpx; b FM119 $\left(990{ }^{\circ} \mathrm{C}\right.$ and $\left.0.6 \mathrm{GPa}\right)$; c FM128 $\left(960{ }^{\circ} \mathrm{C}\right.$ and 0.4 $\mathrm{GPa})$ with pronounced quench crystallisation; d FM145 $\left(870{ }^{\circ} \mathrm{C}\right.$ and $0.4 \mathrm{GPa})$; e FM150 $\left(990{ }^{\circ} \mathrm{C}\right.$ and $\left.0.2 \mathrm{GPa}\right)$; f FM146 $\left(960{ }^{\circ} \mathrm{C}\right.$ and 0.2 $\mathrm{GPa})$ with sector zoned cpx crystal

temperature cycling during the experiment. Plagioclase generally formed small subhedral equant or lath-shaped crystals $(<10 \mu \mathrm{m})$. Zoning of single crystals could not be observed. 


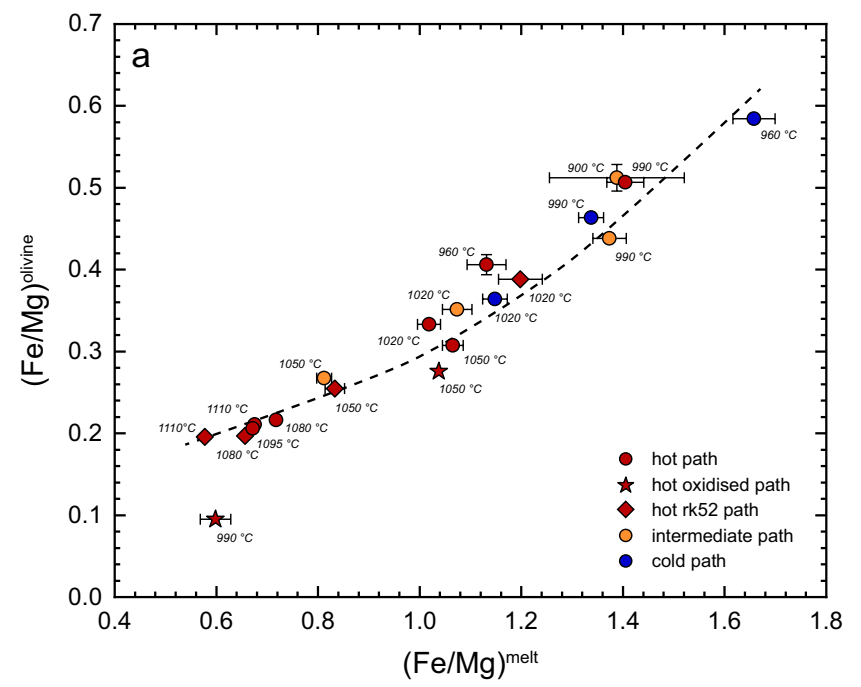

Fig. 4 Molar (Fe/Mg) ratios of mineral phases vs residual melts for olivine (a) and amphibole (b). In cases where error bars are not shown, their extent is smaller than the symbol size. Experimental temperatures are indicated by numbers close to symbols and low-Ti/ high-Ti zones for amphiboles are additionally labelled. The black dot-

At $0.2 \mathrm{GPa}$, plagioclase was distinctively smaller $(<5 \mu \mathrm{m})$ than at higher pressures, resulting in finely dispersed plagioclase in the groundmass glass (Fig. 3e, f). One reason for these specific textures is the pronounced oversaturation in plagioclase at low pressures resulting in rapid nucleation when equilibration P-T conditions are reached. Hercynitic spinel formed small, euhedral crystals $(<5 \mu \mathrm{m})$, which were sometimes difficult to identify in BSE images due to greyscale levels overlapping with clinopyroxene. Amphibole was idiomorphic (Fig. 3c, d), and a decrease of grain sizes with decreasing temperature (from around 100 to $10 \mu \mathrm{m}$ ) was observed. This variation in crystal size can be explained by a change of the nucleation vs crystallisation rates. At high temperatures, close to its stability limit, growth of amphibole is favoured, while at lower temperatures nucleation dominates. This interpretation is supported by the presence of melt and mineral inclusions in amphibole of run FM129, indicating rapid crystal growth. Magnetite varied in size $(<5-30 \mu \mathrm{m})$ and revealed near-perfect cubic crystal habit for most runs, sometimes accompanied by slightly rounded shapes. In run FM146, magnetite contained some melt and mineral inclusions pointing towards delayed nucleation followed by rapid crystallisation (Fig. 3f). Ilmenite was typically rather small $(<5-10 \mu \mathrm{m})$ and of elongated shape, occasionally forming crystal clusters. Orthopyroxene was only observed in a single experiment (FM164) and crystallised as relatively large idiomorphic prisms (up to $200 \mu \mathrm{m}$ length) containing numerous inclusions. Weak sector zonation could be observed on BSE images, which was confirmed by compositional data established by SEM-EDS and EPMA.

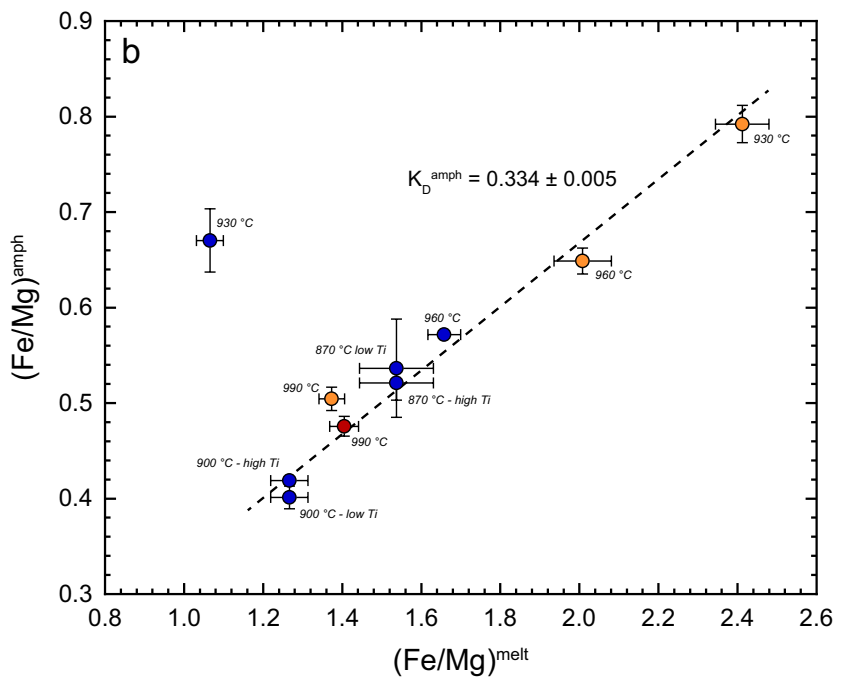

ted line is an eye-ball fit illustrating the continuous increase of $\mathrm{Fe}-$ $\mathrm{Mg} \mathrm{K}_{\mathrm{D}}$ 's with ongoing differentiation. For amphibole, a mean $\mathrm{Fe}-\mathrm{Mg}$ $\mathrm{K}_{\mathrm{D}}$ of $0.334 \pm 0.005$ was determined by linear regression of individual experiments. For more details, see text

Biotite crystallised in run FM145 (Fig. 3d) formed idiomorphic platelets $(\sim 20 \mu \mathrm{m})$, while apatite morphology differed between the two runs where it was present (short prismatic in FM145 and tiny needles in FM164).

\section{Approach to equilibrium}

The following considerations imply that chemical equilibrium was approached to a sufficient level in the polybaric fractional crystallisation experiments: (1) High residual melt fractions of individual experiments ( $>50-70 \mathrm{wt} . \%)$ facilitated the attainment of chemical equilibrium between different mineral phases and silicate liquid. (2) Run textures do not exhibit signs of disequilibrium. Mineral phases were predominantly idiomorphic and devoid of significant chemical zonation. The general absence of relics from unreacted starting material further supports attainment of equilibrium. (3) Quenched experimental liquids were homogenous. Minor variations of reported melt compositions can be related to analytical difficulties (alkali migration) or overlap of WDS signals of adjacent crystals due to the formation of small residual melt pools. Similarly, mineral phases show minor chemical variability in experimental charges and both melt and mineral compositions define smooth and consistent trends along the liquid lines of descent. (4) $\mathrm{Fe}-\mathrm{Mg}$ distribution coefficients between mafic minerals (olivine, clinopyroxene, amphibole) and silicate melt describe systematic variations upon differentiation. $\mathrm{Fe} / \mathrm{Mg}$ ratios of experimental olivine exhibit a non-linear increase with increasing (Fe/ $\mathrm{Mg})^{\text {melt }}$ (Fig. 4a). The non-linear trend between olivine and 

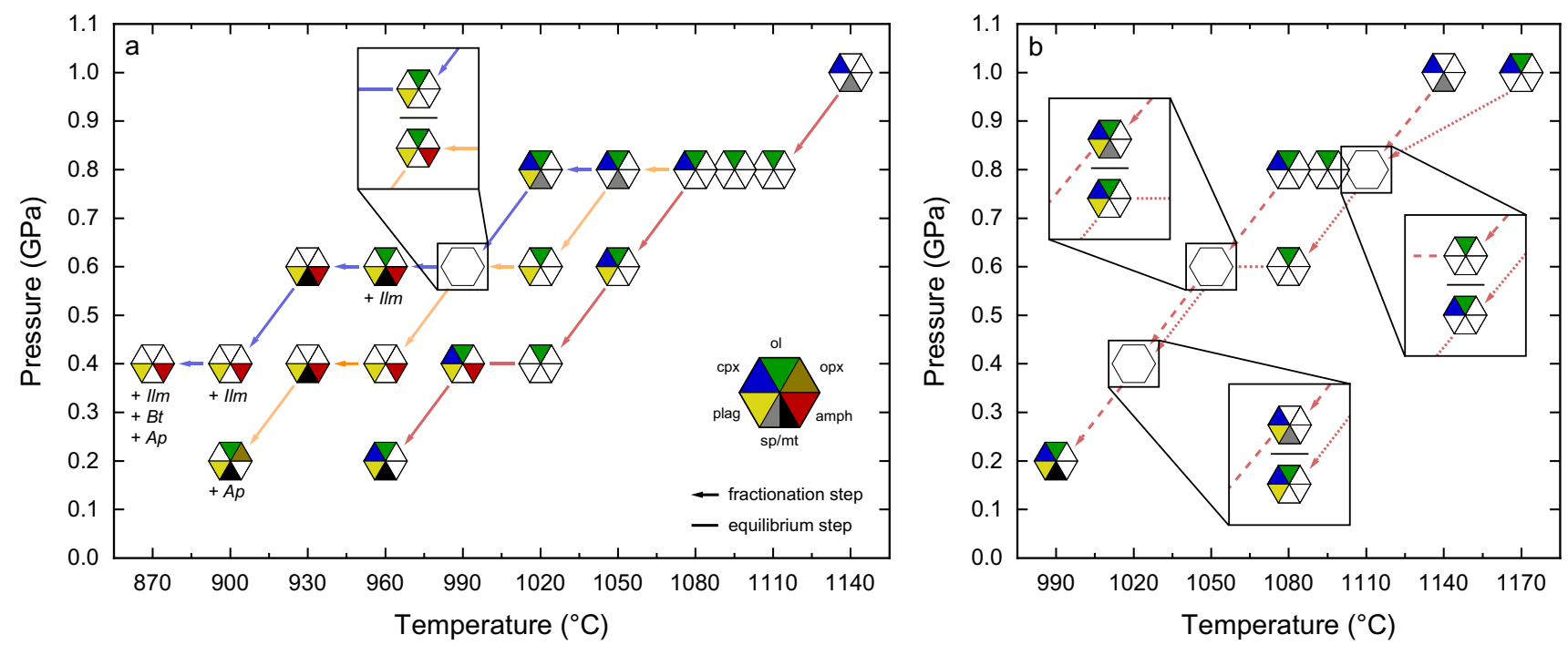

Fig. 5 Phase assemblages of the fractional crystallisation experiments. Colour coding of P-T paths (arrows and lines) is identical to Fig. 1 (red - hot paths, orange - intermediate path, blue - cold path). In case of identical pressure-temperature conditions respective phase equilibria are shown by the zoomed-in cut-outs. Data for the 1.0 GPa runs correspond to reported crystal assemblages by Ulmer et al. (2018). Coloured triangles indicate stable mineral phases coexisting with residual melt and abbreviations are: olivine (ol), clinopyroxene

melt compositions indicates that distribution coefficients vary with changing experimental conditions. A general decrease of equilibration temperature can be observed along the curved trend with steeper slopes (= higher individual $\mathrm{Fe}-\mathrm{Mg} \mathrm{K}$ 's) at lower temperatures. Blundy et al. (2020) showed that olivine $\mathrm{Fe}-\mathrm{Mg} \mathrm{K} \mathrm{C}_{\mathrm{D}}$ 's vary as a function of forsterite contents, with a maximum $\mathrm{K}_{\mathrm{D}}$ at $\mathrm{Fo}_{50}$. Consequently, the observed non-linear trend of decreasing $\mathrm{Fe} / \mathrm{Mg}$ ratios is consistent with the decrease of olivine forsterite contents of our experiments with decreasing temperature (Fig. 8). Only the $990{ }^{\circ} \mathrm{C}$ run of the hot oxidised path falls off this general trend with a $\mathrm{K}_{\mathrm{D}}$ of 0.16 , which is a result of the oxidising $\mathrm{fO}_{2}$ conditions of this experiment $(\approx \mathrm{RRO})$ and the significantly higher $\mathrm{Fe}^{3+}$ content in the melt phase. Amphiboleliquid $\mathrm{Fe}-\mathrm{Mg}$ distribution is illustrated in Fig. 4b. Except for the $930{ }^{\circ} \mathrm{C}$ run of the cold path (FM121), (Fe/Mg) ratios of amphiboles and residual melt display a linear trend with a fitted mean $\mathrm{Fe}-\mathrm{Mg} \mathrm{K}$ D of $0.334 \pm 0.005$. This distribution coefficient is in good accordance with the value of 0.32 from Grove et al. (2003), falls in the range of 0.30-0.38 established by Sisson and Grove (1993a), and agrees with values between 0.35 and 0.40 observed by Martel et al. (1999). The calculated $K_{D}$ of run FM121 $(0.629 \pm 0.037)$ is almost twice the fitted $\mathrm{Fe}-\mathrm{Mg} \mathrm{K}$ D of $0.334 \pm 0.005$. This run crystallised high proportions of magnetite, which could be an indication that $\mathrm{fO}_{2}$ might have been significantly higher than (cpx), plagioclase (plag), amphibole (amph), hercynitic spinel (sp), magnetite (mt), orthopyroxene (opx), ilmenite (ilm), biotite (bt), and apatite (ap). a phase assemblages for the three main series (hot, intermediate, and cold path) and $\mathbf{b}$ results of the hot oxidised and hot rk52 path; the trajectory of the hot oxidised path is illustrated with coarse dashed lines and the hot rk52 path is represented by the fine dashed lines

expected ( $>>\mathrm{NNO})$, although no indications of $\mathrm{fO}_{2}$ buffer failure were noticed. Enhanced incorporation of ferric iron in amphibole combined with abundant magnetite crystallisation could explain the distinctly higher $\mathrm{Fe}-\mathrm{Mg} \mathrm{K}$. Alternatively, the early saturation of amphibole and the delayed onset of magnetite crystallisation in the experiment circumvented a final equilibration in $\mathrm{Fe}-\mathrm{Mg}$ exchange between amphibole and residual liquid. Thus, the $(\mathrm{Fe} / \mathrm{Mg})$ ratio of amphibole rather represents the equilibrium state prior to magnetite saturation, where the melt contained significantly higher amounts of iron and the remaining run duration after the onset of magnetite crystallisation was apparently too short to enable a final re-equilibration in $\mathrm{Fe}-\mathrm{Mg}$ between already crystallised amphibole and residual melt. For clinopyroxene, a mean $\mathrm{Fe}-\mathrm{Mg} \mathrm{K} \mathrm{K}_{\mathrm{D}}$ of $0.276 \pm 0.005$ was established by weighted linear fitting of data points of experiments where $\mathrm{fO}_{2}$ was buffered between NNO-1 and NNO. This value broadly coincides with 0.23 for a hydrous basalt (Sisson and Grove 1993a), 0.24 for a high-Mg andesite (Grove et al. 2003), and 0.25 for andesites (Martel et al. 1999). Clinopyroxenes from the hot oxidised path exhibit higher $\mathrm{Fe}-\mathrm{Mg} \mathrm{K} \mathrm{K}_{\mathrm{D}}$ 's ranging from 0.32 to 0.51 consistent with higher $\mathrm{fO}_{2}(\sim \mathrm{RRO})$ and an enhanced incorporation of ferric iron into clinopyroxene via ferri-tschermaks and acmite components. 

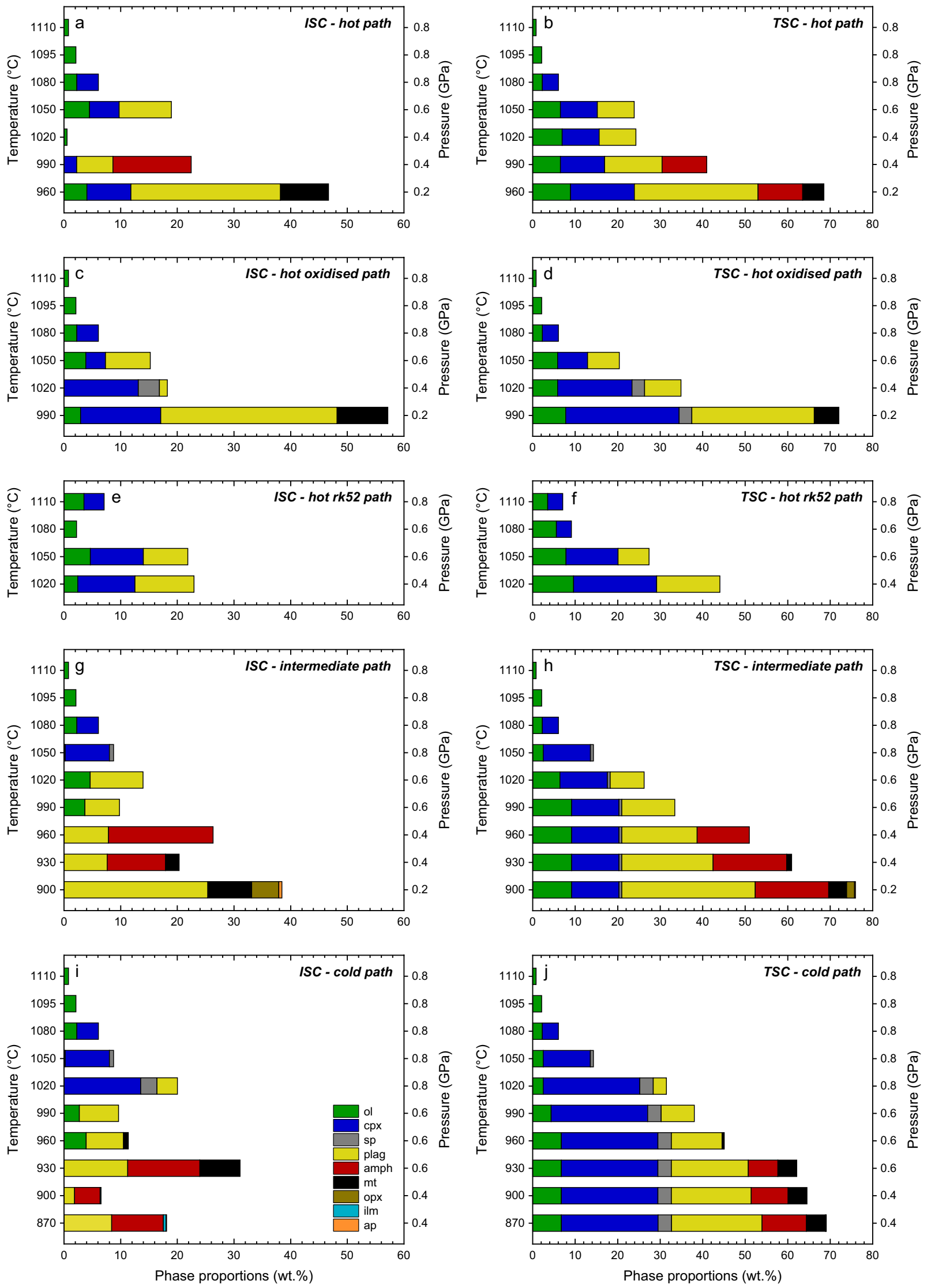
४Fig. 6 Solid phase proportions of fractional crystallisation experiments (in wt.\%); residual melts correspond to the difference to 100 . The left column of bar diagrams reports instantaneous solid compositions (ISC) and the right column corresponds to the accumulated total solid compositions (TSC). See text for further explanations and caption of Fig. 5 for mineral abbreviations

\section{Phase relations and phase proportions}

Stable phase assemblages are illustrated in Fig. 5 and reported in Table 2. The hot, intermediate, and cold path are illustrated in Fig. 5a. The hot path represents the starting point where the primary starting material rk54 is saturated with clinopyroxene and spinel at $1140{ }^{\circ} \mathrm{C}$ and 1.0 $\mathrm{GPa}$. A subsequent decrease in pressure to $0.8 \mathrm{GPa}$ leads to the destabilisation of these two phases and appearance of olivine $\left(1110^{\circ} \mathrm{C}\right)$. With decreasing temperature, clinopyroxene joins olivine at $1080{ }^{\circ} \mathrm{C}$. A next decompression step to $0.6 \mathrm{GPa}$ promotes plagioclase crystallisation at $1050{ }^{\circ} \mathrm{C}$. From 0.6 to $0.4 \mathrm{GPa}$, only olivine remains stable at $1020^{\circ} \mathrm{C}$. After $30{ }^{\circ} \mathrm{C}$ of isobaric cooling, amphibole, plagioclase, and clinopyroxene start crystallising. Finally, a decrease of pressure from 0.4 to $0.2 \mathrm{GPa}$ results in the disappearance of amphibole and magnetite saturation at $960{ }^{\circ} \mathrm{C}$. The intermediate path branches off from the hot path at $1080{ }^{\circ} \mathrm{C}$ via an isobaric cooling step to $1050{ }^{\circ} \mathrm{C}$ resulting in the crystallisation of olivine, clinopyroxene and spinel. Subsequent decompression to $0.6 \mathrm{GPa}$ and $1020{ }^{\circ} \mathrm{C}$ saturates the liquid in plagioclase, while clinopyroxene and spinel disappear. At $990{ }^{\circ} \mathrm{C}$, amphibole joins the stable phase assemblage. Upon a next decompression step to $0.4 \mathrm{GPa}$ and $960{ }^{\circ} \mathrm{C}$ olivine destabilises and with further cooling magnetite starts crystallising at $930{ }^{\circ} \mathrm{C}$. The last pressure and temperature decrease to $0.2 \mathrm{GPa}$ and $900{ }^{\circ} \mathrm{C}$ stabilises olivine, orthopyroxene, and apatite at the expense of amphibole. The cold path leaves the intermediate path at $1050{ }^{\circ} \mathrm{C}$ and $0.8 \mathrm{GPa}$. Plagioclase crystallises at $1020{ }^{\circ} \mathrm{C}$. From 0.8 to $0.6 \mathrm{GPa}$ (and 1020 to $990{ }^{\circ} \mathrm{C}$ ), clinopyroxene and spinel destabilise resulting in a "troctolitic" assemblage (plagioclase + olivine). With progressive cooling, magnetite and amphibole join the solid phase assemblage at $960{ }^{\circ} \mathrm{C}$ (together with trace amounts of ilmenite) while olivine and ilmenite disappear at $930{ }^{\circ} \mathrm{C}$. The subsequent decompression step to $0.4 \mathrm{GPa}$ (and $900{ }^{\circ} \mathrm{C}$ ) stabilises ilmenite at the expense of magnetite. The final isobaric fractionation step to $870{ }^{\circ} \mathrm{C}$ results in the crystallisation of biotite and apatite.

The hot oxidised and hot rk52 path follow similar $\mathrm{P}-\mathrm{T}$ ascent trajectories. However, due to differences in starting material composition and $\mathrm{fO}_{2}$, phase equilibria upon cooling and ascent differ (Fig. 5b). The first three experiments of the hot oxidised path (until $1080{ }^{\circ} \mathrm{C}$ and $0.8 \mathrm{GPa}$ ) are identical with the hot path. Upon decompression to $0.6 \mathrm{GPa}$ and cooling to $1050{ }^{\circ} \mathrm{C}$ plagioclase and hercynitic spinel crystallise. At $0.4 \mathrm{GPa}$ and $1020^{\circ} \mathrm{C}$, olivine disappears, but reappears at $0.2 \mathrm{GPa}$ and $990{ }^{\circ} \mathrm{C}$, where hercynitic spinel is replaced by magnetite. The initial starting material of the hot rk52 path is in equilibrium with olivine and clinopyroxene at $1170{ }^{\circ} \mathrm{C}$ and $1.0 \mathrm{GPa}$ (Ulmer et al. 2018). This mineral assemblage is not changed by decompression to $0.8 \mathrm{GPa}$ and a temperature decrease of $60^{\circ} \mathrm{C}$. The subsequent decrease to 0.6 GPa leads to the destabilisation of clinopyroxene at $1080{ }^{\circ} \mathrm{C}$. Plagioclase joins the phase assemblage upon further isobaric cooling to $1050{ }^{\circ} \mathrm{C}$. Finally, at $0.4 \mathrm{GPa}$ and $1020^{\circ} \mathrm{C}$, the stable mineral assemblage $(\mathrm{ol}+\mathrm{cpx}+\mathrm{plag})$ is identical to the previous fractionation experiment at $1050{ }^{\circ} \mathrm{C}$. In summary, for several polybaric fractionation paths, decompression and cooling stabilised olivine at the expense of clinopyroxene, while plagioclase crystallised at higher temperatures at lower pressures, and amphibole, although present at intermediate pressures $(0.4-0.6 \mathrm{GPa})$, is destabilised during final decompression to $0.2 \mathrm{GPa}$.

Phase proportions of experimental charges, calculated via mass balance regression, are reported in Table 2 and illustrated in Fig. 6. The left column (Fig. 6a, c, e, g, i) corresponds to instantaneous solid compositions (ISC) depicting the modal proportions of minerals crystallising in individual experiments. The right column (Fig. 6b, d, f, h, j) represents total solid compositions (TSC), where phase proportions are expressed relative to the initial starting material (rk54 or rk52), corresponding to the total accumulated amounts of minerals fractionated along the liquid line of descent. TSC fractions were calculated as follows: $\mathrm{TSC}_{\mathrm{n}}=\mathrm{TSC}_{\mathrm{n}-1}+\mathrm{ISC}_{\mathrm{n}}$ * $\mathrm{AMF}_{\mathrm{n}-1}$, where $\mathrm{n}$ corresponds to the experiment of interest, $\mathrm{n}-1$ to the preceding fractionation experiment, and AMF to the absolute residual melt fraction expressed relative to the initial starting material. For most experiments, instantaneous solid compositions are relatively constant and below $30 \mathrm{wt} . \%$. A distinct decrease (more than $10 \mathrm{wt} . \%$ ) is often related to a decompression step of $0.2 \mathrm{GPa}$, due to a shift of phase equilibria with decreasing pressure. This is further enhanced for water-undersaturated experiments because decompression decreases volatile solubility in silicate melts, and, thus, results in an increase of water activity in the experimental charge. The experiments at $0.2 \mathrm{GPa}$ of the hot and hot oxidised path exhibit a strong increase in crystallinity. We propose two possible effects explaining this observation: (1) decompression leads to water-saturated conditions and crystallisation is mainly driven by cooling, and, (2) the negative Clapeyron slope of plagioclase and magnetite results in extensive crystallisation of these phases. 
In contrast, accumulated crystal fractions of the intermediate and cold path display continuously increasing mineral proportions with progressive cooling. A comparison of relative mineral proportions between the five different fractionation paths reveals that phase relationships between olivine, clinopyroxene, and plagioclase are crucial. For the coolingdominated ascent path (cold path) the extent of clinopyroxene crystallisation is higher with respect to the more decompression-controlled P-T trajectory (hot path). Relative proportions of crystallised plagioclase and olivine are slightly higher for the latter fractionation trend. For the hot oxidised path, higher amounts of oxides (hercynitic spinel or magnetite) formed due to distinctly more oxidising $\mathrm{fO}_{2}$ conditions, stabilising $\mathrm{Fe}^{3+}$-bearing mineral phases. The hot rk52 path fractionated almost double the amount of crystals compared to the hot path (44 wt.\% vs 24 wt.\%) at $1020^{\circ} \mathrm{C}$. This is an expression of the more primitive character of the rk52 starting material promoting extensive crystallisation with ongoing cooling.

\section{Compositions of major phases}

Compositions of major experimental phases (residual melts and coexisting minerals) were measured by EPMA and are reported in Table 3 and the Electronic Supplementary Material ESM 6.

\section{Residual liquids}

The evolution of major and minor oxide compositions of residual liquids with decreasing temperature (on an anhydrous base) is illustrated in Fig. 7. Liquid lines of descent follow calc-alkaline differentiation trends with increasing silica and alkali contents accompanied by a decrease of other compounds (e.g. $\mathrm{MgO}, \mathrm{FeO}$, and $\mathrm{CaO}$ ), thereby evolving from basaltic to dacitic compositions. However, some distinct features can be identified, which are either valid for all five fractional crystallisation paths or only affect individual trajectories. Since several fractionation series exhibit similar evolution trends, the following umbrella terms are used in the remainder of this manuscript to facilitate the description of the observed patterns: the hot and hot oxidised path are called decompression-dominated, while the intermediate and cold path are referred to as cooling-dominated.

Silica contents increase with decreasing temperature from 48 to 67 wt.\% (Fig. 7a). In detail, this trend of silica enrichment can be divided in a high-temperature interval with only a minor increase in $\mathrm{SiO}_{2}$, followed by a low-temperature stage with pronounced silica enrichment over a narrow temperature range. The onset of $\mathrm{SiO}_{2}$ enrichment is shifted to higher temperatures $\left(990-1020^{\circ} \mathrm{C}\right.$ ) for the decompression-dominated series compared to the cooling-dominated ones (960-990 ${ }^{\circ} \mathrm{C}$ ) because of phase equilibria control. At high temperatures, the chemical evolution of residual liquids is governed by fractionation of olivine, clinopyroxene, and \pm plagioclase. At lower temperatures, crystallisation of amphibole, anorthite-rich plagioclase, and an Fe-Ti-oxide results in a rapid increase of silica. $\mathrm{Al}_{2} \mathrm{O}_{3}$ reveals distinct bell-shaped trends with an initial increase followed by a plateau and a subsequent decrease (Fig. 7c). For the decompression-dominated series, maximum levels of $\mathrm{Al}_{2} \mathrm{O}_{3}$ are lower ( $<20.0 \mathrm{wt} . \%)$ than for the cooling-dominated trajectories (>20.0 wt.\%), consistent with enhanced plagioclase stability at lower pressures. Similar to alumina, $\mathrm{TiO}_{2}$ exhibits an initial enrichment followed by a rapid decrease with variable inflection points (i.e. temperatures) for the individual FC series (Fig. 7b). These inflexion temperatures can be related to the onset of amphibole crystallisation. With decreasing temperature, saturation in ilmenite or Ti-bearing magnetite further depletes the residual melt in titanium. The hot oxidised path does not exhibit a late-stage decrease in $\mathrm{TiO}_{2}$, although magnetite saturation was reached. This feature is explained by low $\mathrm{TiO}_{2}(\sim 2.9$ wt.\%) but high ferric iron contents in magnetite and the absence of amphibole in the crystallisation sequence.

$\mathrm{FeO}$ contents of residual liquids reveal a plateau with significant variability at high temperatures and a pronounced decrease initiating between 990 and $930{ }^{\circ} \mathrm{C}$ related to the saturation of Fe-Ti-oxides (Fig. 7d). MnO exhibits evolution trends mirroring iron with an initial increase, followed by a decrease when Fe-Ti-oxide saturation is reached (Fig. 7e). A linear decrease of $\mathrm{MgO}$ contents of residual liquids is observed with ongoing cooling (Fig. 7f) for all five FC paths. $\mathrm{CaO}$ contents exhibit an initial plateau followed by a continuous decrease with progressive cooling with inflexion points corresponding to clinopyroxene saturation (Fig. 7g). In detail, the cold path exhibits an almost linear trend, as clinopyroxene stability is enhanced at higher pressures, whereas the intermediate and hot path reveal only a minor $\mathrm{CaO}$ decrease from 1050 to $990{ }^{\circ} \mathrm{C}$ which is related to the decompression steps resulting in a destabilisation of clinopyroxene and a re-appearance of olivine. The rapid decrease of $\mathrm{CaO}$ observed for the last temperature step of the hot, hot oxidised, and intermediate path is related to the final decompression to $0.2 \mathrm{GPa}$ coinciding with enhanced plagioclase crystallisation (c.f. Figure 6). The hot rk52 path reveals higher $\mathrm{CaO}$ concentrations during early stages of differentiation related to higher initial $\mathrm{CaO}$ contents, but approaches the other fractionation series at $1020{ }^{\circ} \mathrm{C}$.

$\mathrm{Na}_{2} \mathrm{O}$ and $\mathrm{K}_{2} \mathrm{O}$ contents of experimental liquids define similar increasing trends with decreasing temperature, indicating an incompatible behaviour of both elements (Fig. 7h,i). Pronounced enrichments (hot, hot oxidised, intermediate path) correlate with intervals of enhanced crystallisation. The incompatible character of $\mathrm{Na}_{2} \mathrm{O}$ is an expression of the anorthite-rich nature of plagioclase. For 


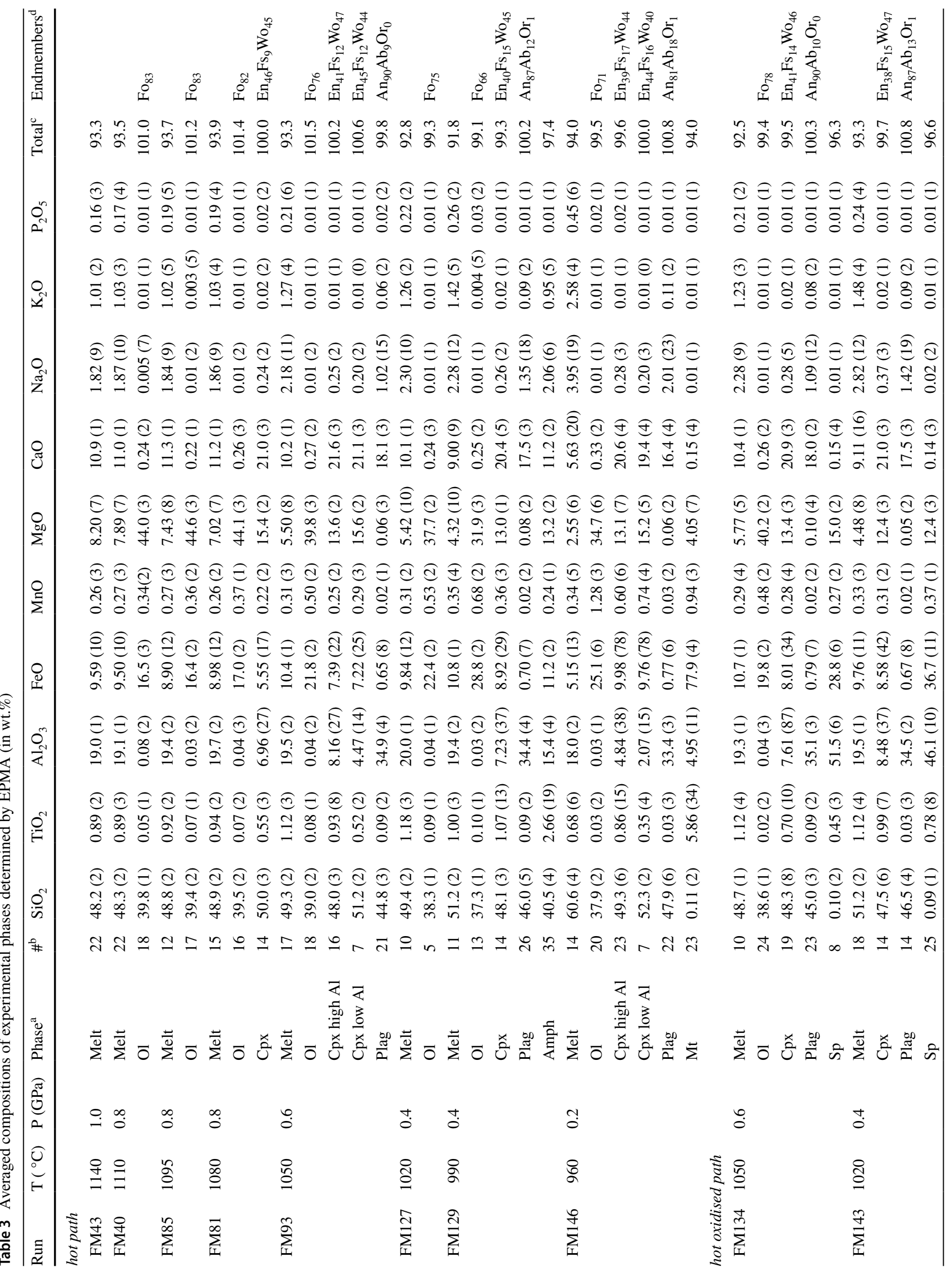




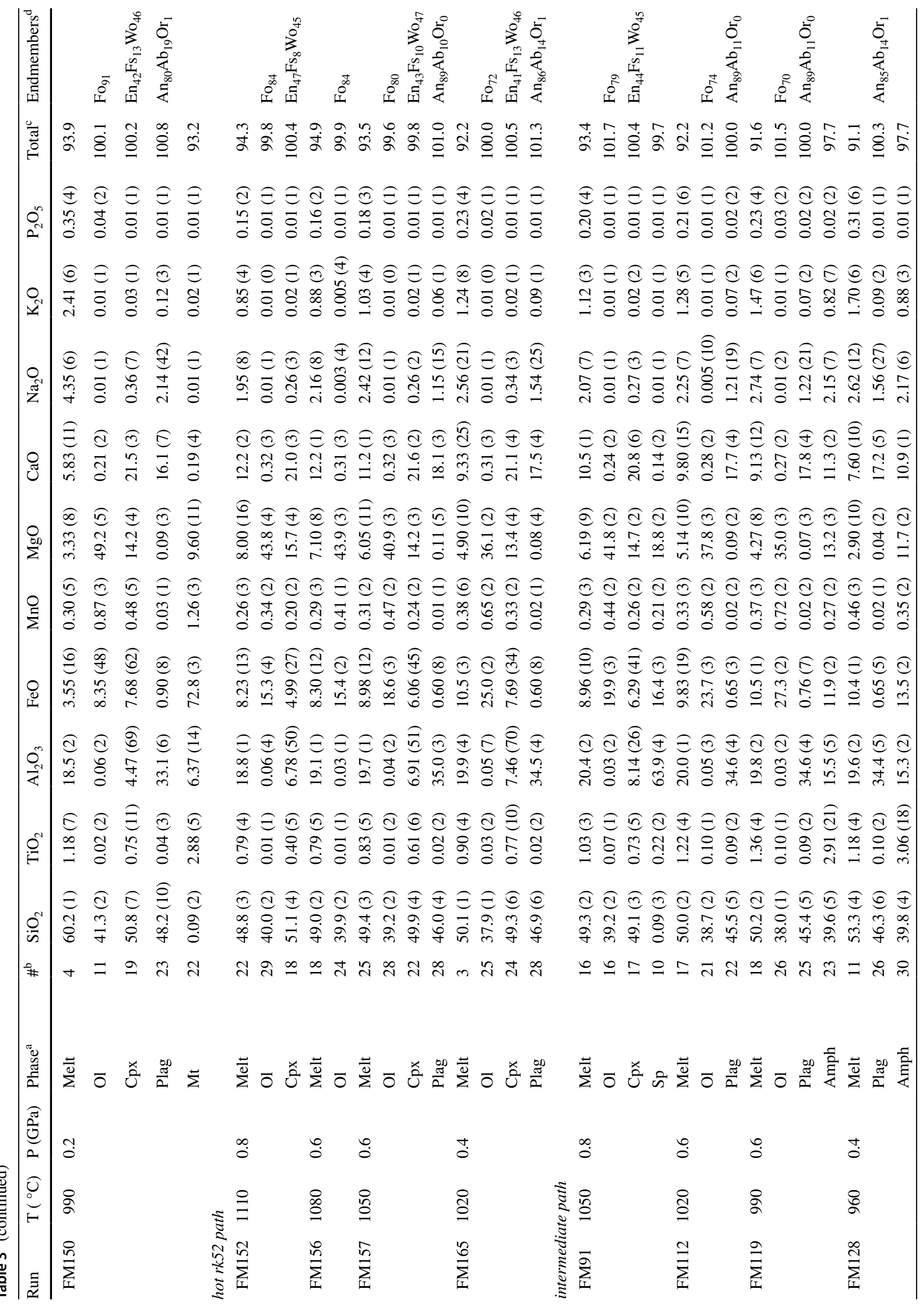




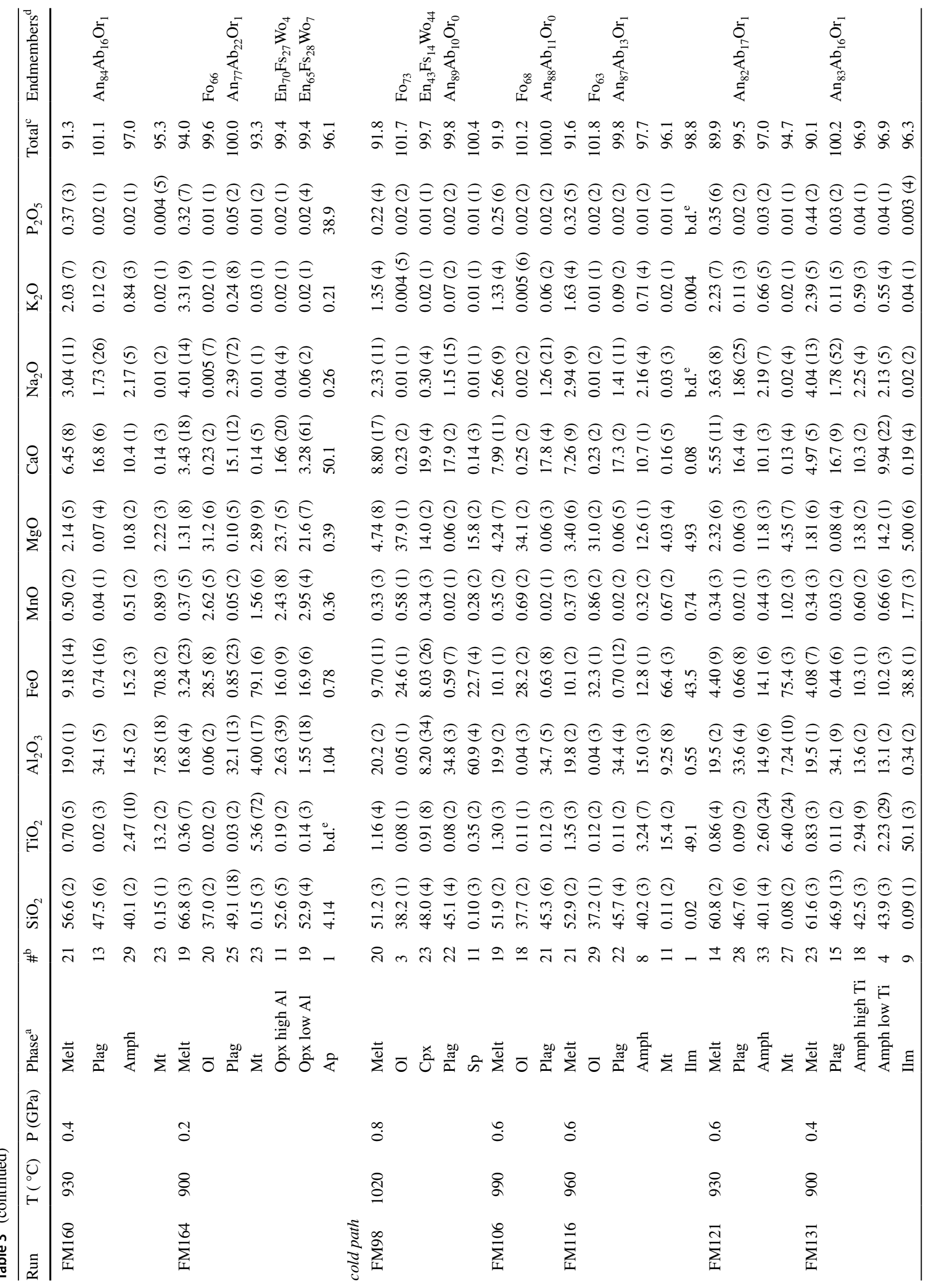




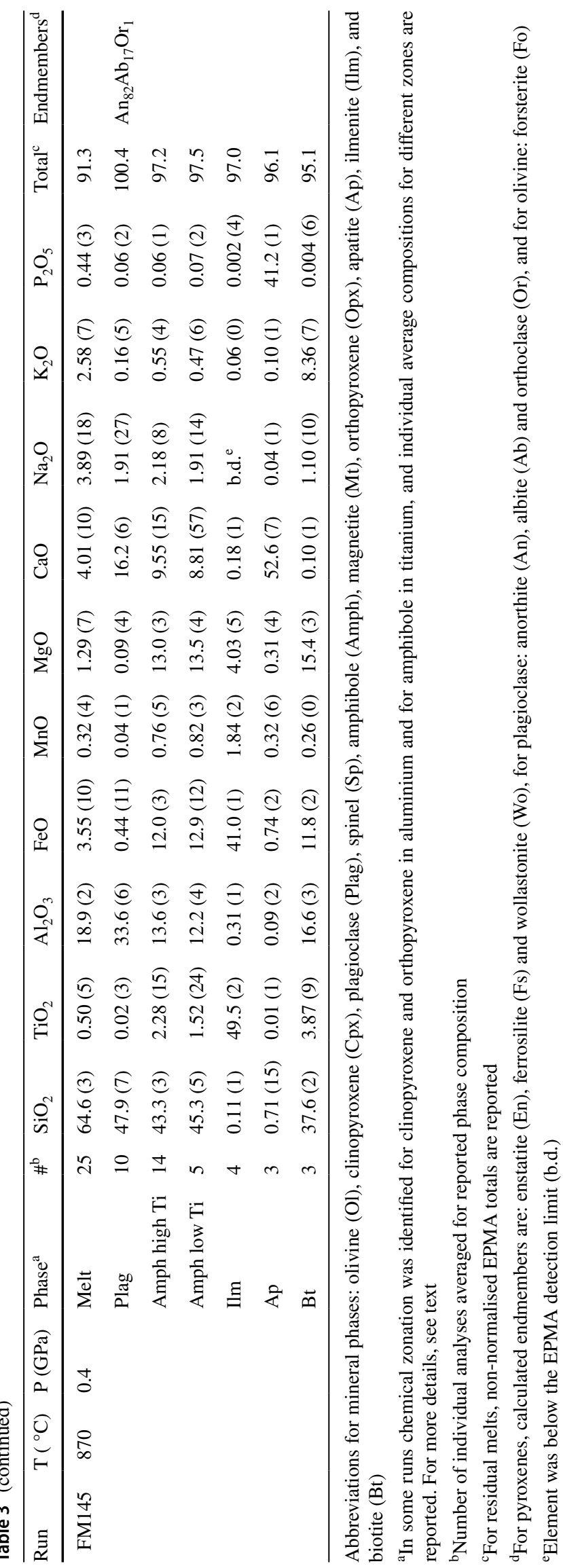


Fig. 7 Oxide concentrations (in wt.\%) of experimental liquids (in wt.\%) recalculated on an anhydrous base (normalisation of EPMA data to $100 \mathrm{wt} \%$ ) as a function of temperature (in ${ }^{\circ} \mathrm{C}$ ). In case error bars are not shown, their extent is smaller than the symbol size
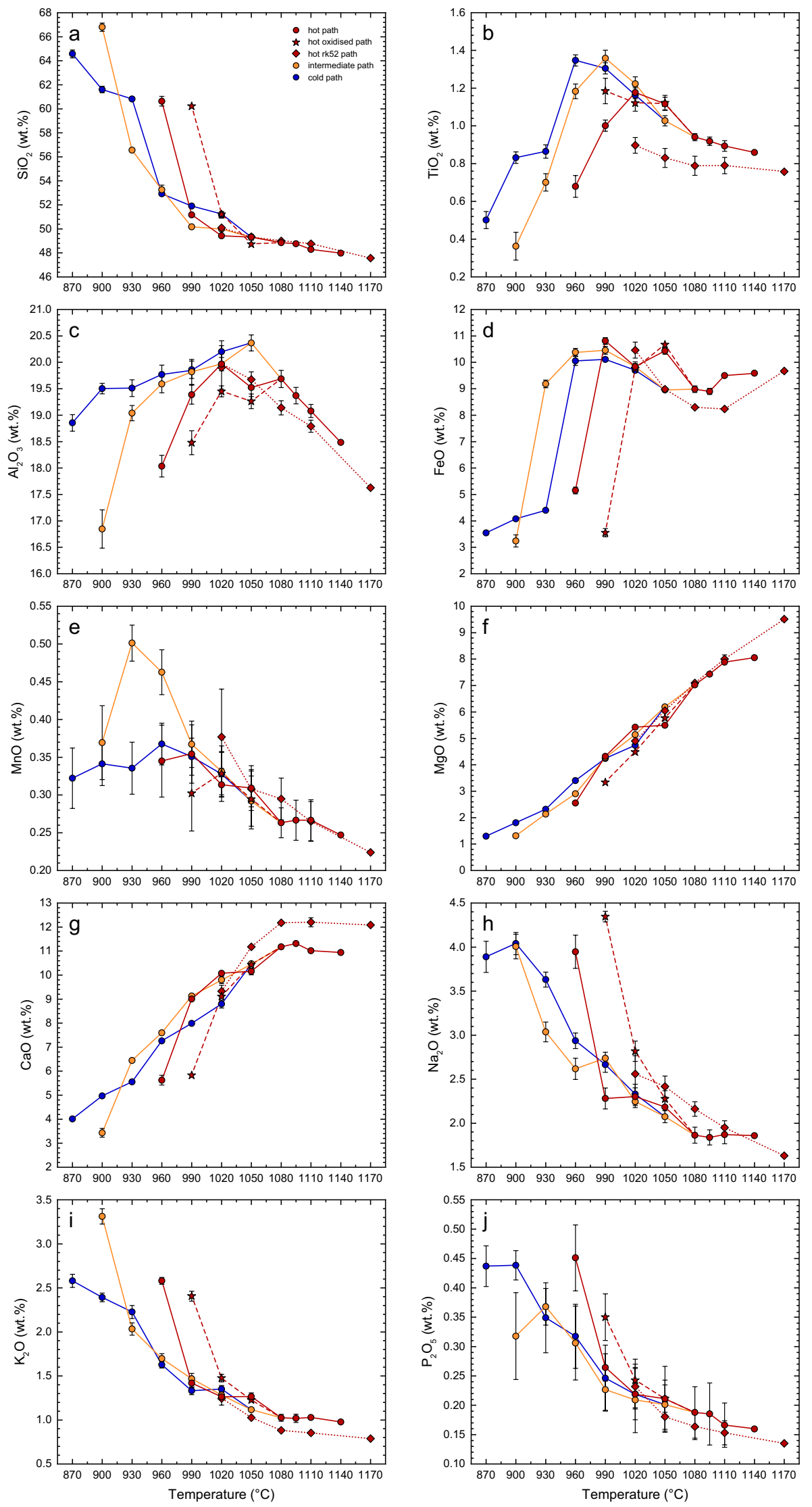

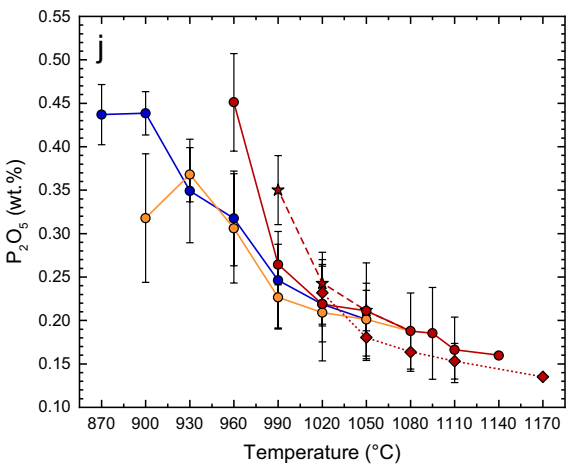


the cold path, plagioclase crystallised at $870{ }^{\circ} \mathrm{C}$ exhibits a distinctly higher albite component, resulting in a decrease of $\mathrm{Na}_{2} \mathrm{O}$ in the coexisting liquid. For potassium, the flattening of the curve expressed by the cold path at low temperatures coincides with the saturation of biotite at $870{ }^{\circ} \mathrm{C}$. Although errors are significant, $\mathrm{P}_{2} \mathrm{O}_{5}$ concentrations of residual melts (Fig. 7j) reveal an incompatible behaviour. For the intermediate and cold path, a decrease/flattening of the trends observed at $900{ }^{\circ} \mathrm{C}$ and $870{ }^{\circ} \mathrm{C}$ perfectly coincides with apatite saturation.

\section{Olivine}

Olivine was stable over a wide temperature range $\left(900-1110{ }^{\circ} \mathrm{C}\right)$ since pressure decrease considerably expanded the olivine stability field. Olivine re-appeared upon decompression to $0.2 \mathrm{GPa}$ for the hot oxidised $\left(990^{\circ} \mathrm{C}\right)$ and the intermediate path $\left(900{ }^{\circ} \mathrm{C}\right)$ although being absent in previous higher pressure-temperature experiments. Molar forsterite contents $\left(\mathrm{X}_{\mathrm{Fo}}\right)$ range from 0.91 to 0.63 (Fig. 8). Olivines crystallised at high temperatures $\left(1050-1110{ }^{\circ} \mathrm{C}\right)$ exhibit $\mathrm{X}_{\mathrm{Fo}}$ of $0.82-0.84$. With ongoing cooling, olivines evolve towards more fayalitic compositions $\left(\mathrm{X}_{\mathrm{Fo}}\right.$ of 0.63-0.70). For the hot oxidised and the hot path, the situation is more complex: in both series, extensive magnetite crystallisation was observed in the lowest temperature runs (FM146 and FM150) resulting in a re-increase of $\mathrm{X}_{\mathrm{Fo}}$ from 0.78 to 0.91 (hot oxidised path) and 0.66 to 0.71 (hot path). The very high forsterite content in the $990{ }^{\circ} \mathrm{C}$ run of the hot-oxidised path $\left(\mathrm{X}_{\mathrm{Fo}}\right.$ of 0.91$)$ is related to the combined effects of (1) extensive magnetite crystallisation and (2) an increased $\mathrm{Fe}^{3+} / \mathrm{Fe}_{\text {tot }}$ ratio in the melt due to oxidising run conditions ( $\mathrm{fO}_{2} \sim \mathrm{RRO}$ ). $\mathrm{MnO}$ contents of olivine increase with decreasing temperature, reaching a maximum of 2.6 wt. $\%$ at $900{ }^{\circ} \mathrm{C}$ for the intermediate path, while $\mathrm{CaO}$ concentrations vary between 0.21 and 0.33 wt. $\%$.

\section{Clinopyroxene}

Experimental clinopyroxenes range between diopside and augite and contain considerable amounts of $\mathrm{Al}_{2} \mathrm{O}_{3}$ (2.1-8.5 wt.\%, see Table 3). Sector zoning (e.g. in $\mathrm{Al}_{2} \mathrm{O}_{3}$ and $\mathrm{TiO}_{2}$ contents) was observed for two runs of the hot path (FM93 at $1050{ }^{\circ} \mathrm{C}$ and $\mathrm{FM} 146$ at $960{ }^{\circ} \mathrm{C}$ ). There is no consensus if either one of the two sectors represents the "true" equilibrium composition to be expected at respective $\mathrm{P}-\mathrm{T}$ conditions or if an average composition between both sectors would be more appropriate (e.g. Schwandt and Mckay 2006; Nandedkar et al. 2014). However, we infer that high-Al sectors represent equilibrium values. Clinopyroxene compositions derived by EPMA were normalised following the procedure of Wood and Banno (1973).

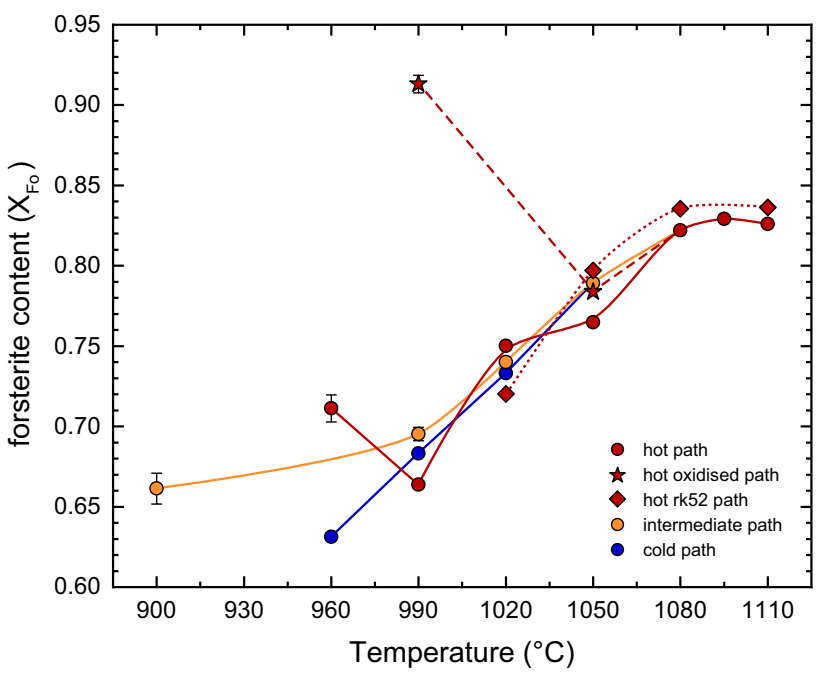

Fig. 8 Molar forsterite contents of experimental olivine as a function of run temperature. In case error bars are not shown, their extent is smaller than the symbol size

Tetrahedral aluminium contents $\mathrm{Al}^{\mathrm{IV}}$ (in atoms per formula unit, a.p.f.u.) exhibit a well-established negative linear correlation with the sum of ferrous iron and magnesium $\left(\mathrm{Fe}^{2+}+\mathrm{Mg}\right)$ (Fig. 9a). This trend is almost parallel to the ideal trajectory of the Tschermak's exchange vector $\left(\mathrm{Fe}^{2+}, \mathrm{Mg}\right) \mathrm{Si}=\mathrm{Al}^{\mathrm{VI}} \mathrm{Al}^{\mathrm{IV}}$ (black arrow in Fig. 9a) revealing that tetrahedral aluminium incorporation in experimental clinopyroxenes is strongly controlled via the Tschermak's substitution. Ti contents of clinopyroxenes (in a.p.f.u.) plotted against temperature show an initial increase followed by a late-stage depletion (Fig. 9b). These trends perfectly match $\mathrm{TiO}_{2}$ evolution trajectories of coexisting residual liquids (Fig. 7b) indicating that $\mathrm{Ti}$ incorporation in clinopyroxene is controlled by the melt composition (and, thus, indirectly the saturation of $\mathrm{Fe}-\mathrm{Ti}$-oxides). Total aluminium $\left(\mathrm{Al}_{\mathrm{tot}}\right.$, in a.p.f.u.) as a function of temperature exhibits a bell-shaped behaviour (Fig. 9c). In an initial stage, $\mathrm{Al}$ in clinopyroxene increases with decreasing temperature, followed by a rapid decrease at lower temperatures. This trajectory is consistent with the $\mathrm{Al}_{2} \mathrm{O}_{3}$ evolution of residual liquids, indicating that melt composition (and, therefore, plagioclase saturation) controls $\mathrm{Al}$ in clinopyroxene. In addition, increasing silica activity in the melt shifts the Tschermak's substitution to the silica-rich side resulting in a depletion of clinopyroxene in Al. Sodium contents of experimental clinopyroxenes exhibit a weak increase with ongoing cooling consistent with an enrichment of residual melts in $\mathrm{Na}_{2} \mathrm{O}$ (Fig. 9d). Alternatively, a slight increase in $\mathrm{fO}_{2}$ with decreasing temperature could favour a simultaneous increase of the acmite/aegirine component $\left(\mathrm{NaFe}^{3+} \mathrm{Si}_{2} \mathrm{O}_{6}\right)$. Variations in $\mathrm{fO}_{2}$ could also 

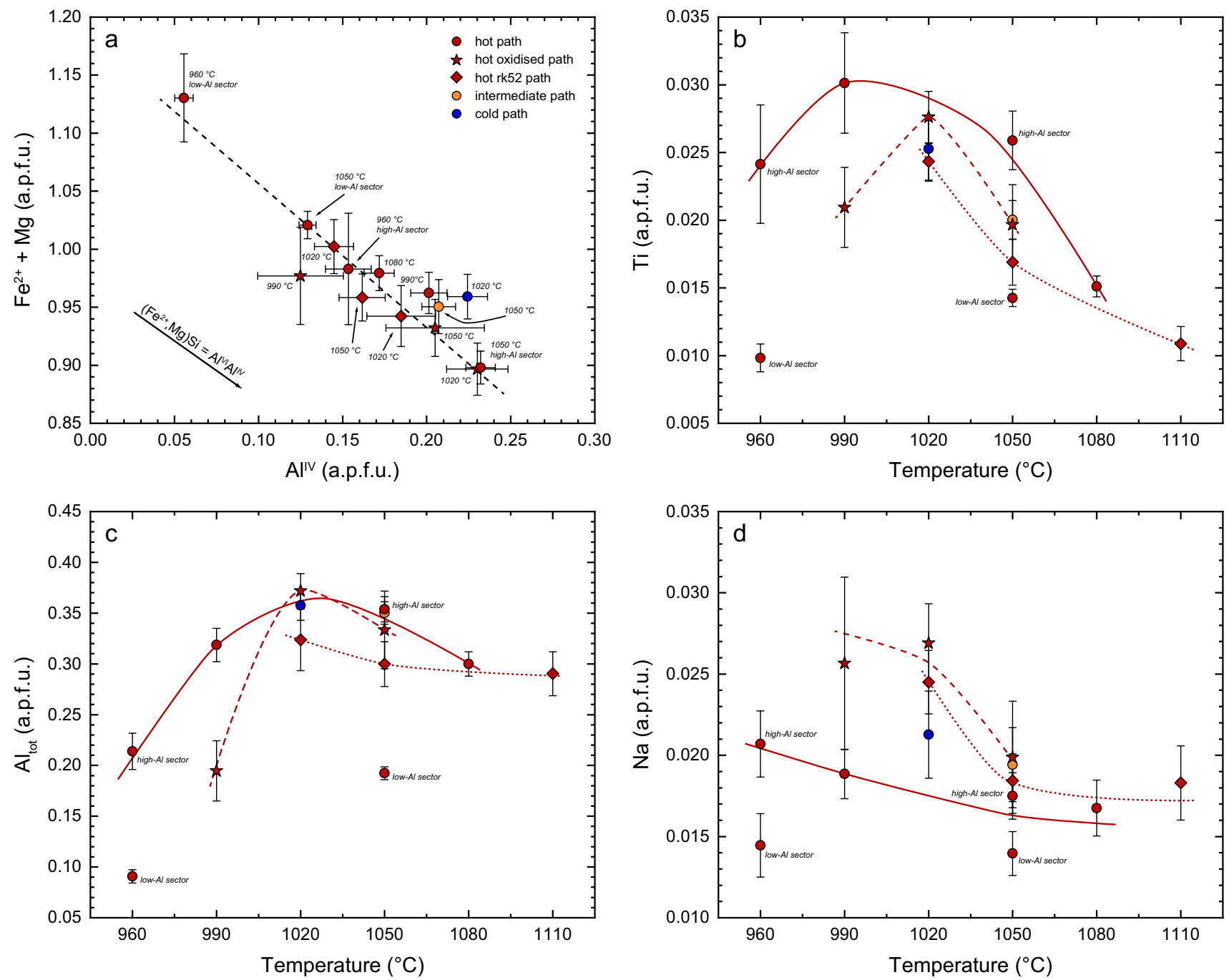

Fig. 9 Compositional trends of experimental clinopyroxenes: a $\mathrm{Fe}^{2+}+\mathrm{Mg}$ vs tetrahedral aluminium $\mathrm{Al}^{\mathrm{IV}}$ in atoms per formula unit (a.p.f.u.). The arrow in the lower left corner corresponds to the ideal trajectory of the Tschermak's vector $\left(\mathrm{Fe}^{2+}, \mathrm{Mg}\right) \mathrm{Si}=\mathrm{Al}^{\mathrm{VI}} \mathrm{Al}^{\mathrm{IV}} ; \mathbf{b} \mathrm{Ti}$ (in a.p.f.u.) vs run temperature; $\mathbf{c}$ total aluminium $\left(\mathrm{Al}_{\mathrm{tot}}\right)$ as a func-

explain the higher $\mathrm{Na}$ contents of clinopyroxenes synthesised along the hot oxidised path $\left(\mathrm{fO}_{2} \sim \mathrm{RRO}\right)$.

\section{Amphibole}

Amphibole crystallised over a restricted temperature interval $\left(870-990^{\circ} \mathrm{C}\right)$ mostly because decompression resulted in an overall destabilisation of amphibole (e.g. Allen et al. 1975; Blatter et al. 2013). As a consequence, amphibole was absent in the decompression-dominated fractionation paths (except for run FM129 of the hot path). Synthesised amphiboles range from pargasite at high temperatures $\left(990{ }^{\circ} \mathrm{C}\right)$, to ferroan pargasite $\left(930-960^{\circ} \mathrm{C}\right)$, and tschermakitic hornblende or magnesiohornblende at low temperatures $\left(870-900{ }^{\circ} \mathrm{C}\right)$.

tion of experimental temperature; $\mathbf{d} \mathrm{Na}$ vs temperature. Compositions of individual sectors of zoned clinopyroxenes identified in two runs of the hot path (high- and low-Al sectors) are explicitly labelled. For more details, see text

Amphibole compositions were recalculated with the normalisation algorithm RAMP (Spear and Kimball 1984) with an empirical $\mathrm{Fe}^{3+} / \mathrm{Fe}_{\text {tot }}$ ratio of 0.20 , representing a value in the range established by Clowe et al. (1988) for a tschermakitic hornblende at $\mathrm{fO}_{2}$ between QFM and NNO.

With decreasing temperature, $\mathrm{Si}$ contents of amphibole increase from 5.8 atoms per formula unit (a.p.f.u.) at $990{ }^{\circ} \mathrm{C}$ to 6.6 a.p.f.u. at $870{ }^{\circ} \mathrm{C}$ (Fig. 10a). Amphiboles synthesised in two low-temperature runs from the cold path (FM131, $900{ }^{\circ} \mathrm{C}$ and $\mathrm{FM} 145,870{ }^{\circ} \mathrm{C}$ ) exhibit a faint chemical zonation (not visible in BSE images), most prominent in Ti concentrations. Si contents of low-Ti zones are higher compared to coexisting high-Ti ones (6.4 and 6.6 a.p.f.u. vs 6.2 and 6.3 a.p.f.u.) as Ti contents are controlled via the Ti-Tschermak's exchange (see below) where enhanced Ti incorporation 

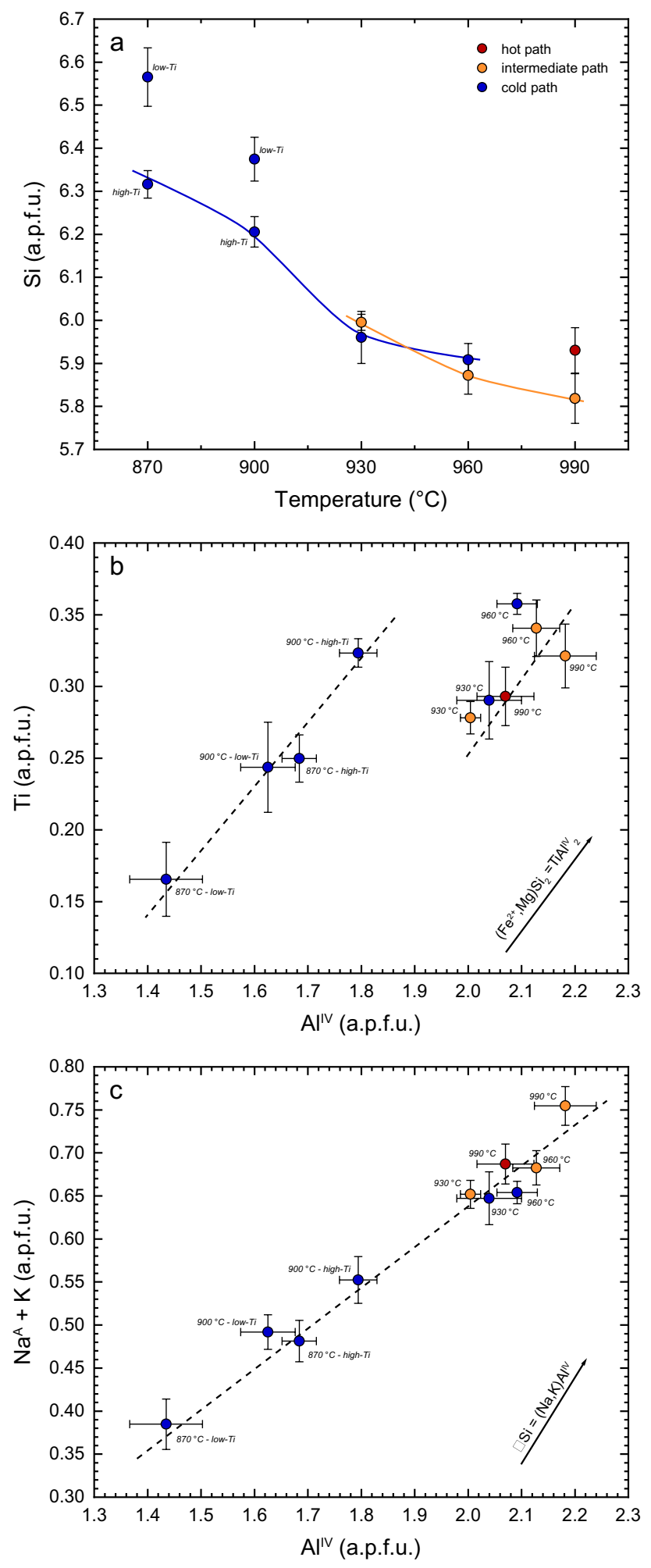

Fig. 10 Compositional trends of experimental amphiboles: a $\mathrm{Si}$ contents in atoms per formula unit (a.p.f.u.) as a function of run temperature; b Ti vs tetrahedral aluminium $\left(\mathrm{Al}^{\mathrm{IV}}\right)$. The black arrow in the lower right corner exemplifies the trajectory of the ideal TiTschermak's exchange vector $\left(\left(\mathrm{Fe}^{2+}, \mathrm{Mg}\right) \mathrm{Si}_{2}=\mathrm{TiAl}^{\mathrm{IV}}{ }_{2}\right)$; c $\mathrm{Al}^{\mathrm{IV}}$ plotted against the sum of alkalis on the A-site $\left(\mathrm{Na}^{\mathrm{A}}+\mathrm{K}\right)$. The arrow in the lower right corner illustrates the trajectory of the ideal edenite exchange vector $\left(\square \mathrm{Si}=(\mathrm{Na}, \mathrm{K}) \mathrm{Al}^{\mathrm{IV}}\right)$ coincides with elevated $\mathrm{Al}$ and lower $\mathrm{Si}$ contents. Ti plotted against $\mathrm{Al}^{\mathrm{IV}}$ reveals well-defined positive correlations allowing the identification of two distinct subparallel trajectories (Fig. 10b). Slopes of $\mathrm{Al}^{\mathrm{IV}}$ vs Ti are parallel to the ideal Ti-Tschermak's vector $\left(\left(\mathrm{Fe}^{2+}, \mathrm{Mg}\right) \mathrm{Si}_{2}=\mathrm{TiAl}^{\mathrm{IV}}{ }_{2}\right.$, black arrow) implying that incorporation of $\mathrm{Ti}$ in amphiboles is controlled by the Ti-Tschermak's exchange reaction. The expression of two trajectories could be related to the rapid increase of Si contents between 930 and $900{ }^{\circ} \mathrm{C}$ resulting in lower $\mathrm{Al}^{\mathrm{IV}}$ and a change in co-crystallising $\mathrm{Fe}-\mathrm{Ti}$-oxides from Ti-bearing magnetite to ilmenite. Apparently, the coexistence with ilmenite slightly enhances the incorporation of Ti in amphiboles compared to the coexistence with magnetite ( $\mathrm{Ti}$ content of 0.29 a.p.f.u. at $930{ }^{\circ} \mathrm{C}$ and 0.32 a.p.f.u. at $\left.900{ }^{\circ} \mathrm{C}\right)$. Total alkali contents on the A-site $\left(\mathrm{Na}^{\mathrm{A}}+\mathrm{K}\right)$ exhibit a positive correlation with tetrahedral aluminium and show a continuous decrease with decreasing temperature (Fig. 10c) consistent with the well-known temperature dependence of the edenite vector $\left(\square \mathrm{Si}=(\mathrm{Na}, \mathrm{K}) \mathrm{Al}^{\mathrm{IV}}\right)$ (e.g. Holland and Blundy 1994).

The attainment of experimental equilibrium was tested calculating crystallisation temperatures employing the richterite-edenite thermometer by Holland and Blundy (1994) and resulting temperatures deviate $1-41{ }^{\circ} \mathrm{C}$ from effective run temperatures, in excellent agreement within the reported algorithm uncertainty $\left(35-40^{\circ} \mathrm{C}\right)$. Temperatures established for low-Ti zones of zoned amphiboles are distinctively off from experimental conditions unlike the high-Ti zones indicating that high-Ti amphibole compositions represent "real" equilibrium, whereas low-Ti ones are experimental relics, probably corresponding to partly-reacted metastable clinopyroxene. The algorithms of Ridolfi et al. (2010) and Ridolfi and Renzulli (2012) resulted in significant deviations from run conditions and strongly overestimate experimental temperatures (up to $195^{\circ} \mathrm{C}$ ), with increasing offset with decreasing temperature. Similarly, derived pressures and melt $\mathrm{H}_{2} \mathrm{O}$ contents are highly variable and do not match experimental run conditions. Thus, the amphibole thermobarometers of Ridolfi et al. (2010) and Ridolfi and Renzulli (2012) failed to reproduce experimental run conditions.

\section{Plagioclase}

Plagioclase crystallised over a wide temperature range $\left(1050-870{ }^{\circ} \mathrm{C}\right.$ ) and occurred at pressures between 0.2 and $0.8 \mathrm{GPa}$. Anorthite contents reveal that plagioclase is anorthite-rich $\left(\mathrm{An}_{90}-\mathrm{An}_{77}\right)$ and displays a consistent decrease with decreasing temperature for all five fractionation paths (Fig. 11a). The hot, hot oxidised, and intermediate path demonstrate a more pronounced decrease of anorthite contents for the last temperature step investigated, coinciding with an increase of coexisting residual liquids in $\mathrm{Na}_{2} \mathrm{O}$ (Fig. 7h). Although $\mathrm{Na}$ contents of the melt are also progressively 


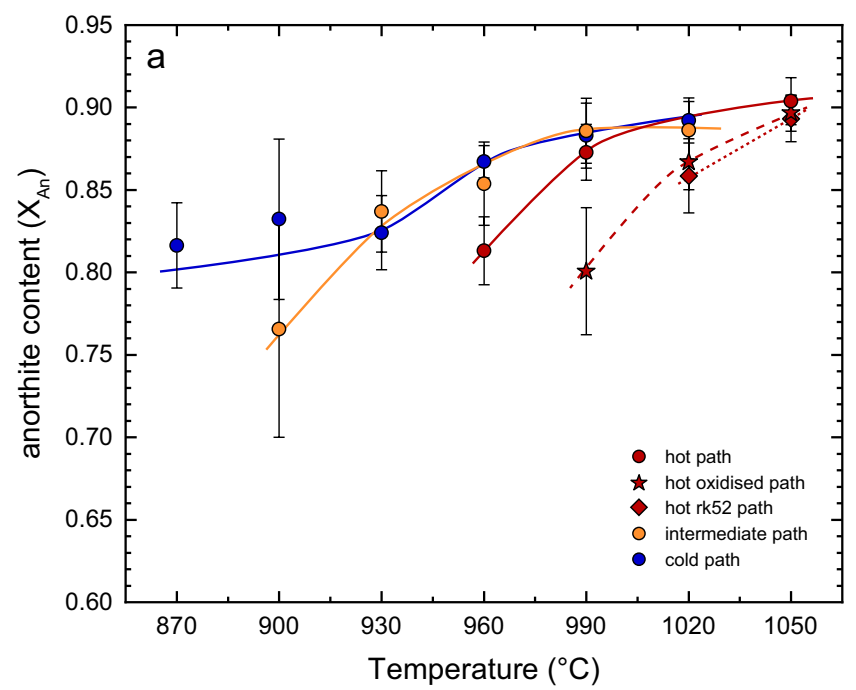

Fig. 11 Compositions of experimental plagioclases: a anorthite contents vs temperature; $\mathbf{b}(\mathrm{Ca} / \mathrm{Na})$ distribution characteristics between plagioclase and residual melt. Trajectories for various $\mathrm{Ca}-\mathrm{Na} \mathrm{K}_{\mathrm{D}}$ 's

increasing along the cold path, the decrease in anorthite is less pronounced. This difference can be explained considering water-saturation levels of the various experimental series. The lowest temperature runs of the hot, hot oxidised and intermediate path were performed at $0.2 \mathrm{GPa}$ and, thus, water-saturation was reached in these charges. For $\mathrm{H}_{2} \mathrm{O}$-undersaturated magmas, crystallisation with decreasing temperatures enriches residual melts in $\mathrm{H}_{2} \mathrm{O}$ and, thus, increases water activity. $\mathrm{H}_{2} \mathrm{O}$ activity also increases due to decreasing $\mathrm{H}_{2} \mathrm{O}$ solubility in silicate liquids with decreasing pressure (e.g. Hamilton et al. 1964; Shishkina et al. 2010; Ghiorso and Gualda 2015). Sisson and Grove (1993a) demonstrated that increasing water activity leads to the stabilisation of anorthite relative to the albite component in plagioclase. Thus, increasing $\mathrm{H}_{2} \mathrm{O}$ activities in nominally water-undersaturated magmas with ongoing differentiation suppress a pronounced decrease of anorthite contents of plagioclase. Upon water-saturation, this effect vanishes, and plagioclase compositions are controlled by the $\mathrm{Na}-\mathrm{Ca}$ systematics of coexisting liquids. Although the last two experiments $\left(870\right.$ and $900{ }^{\circ} \mathrm{C}$ ) of the cold path at $0.4 \mathrm{GPa}$ reached water-saturation (Table 2), plagioclase anorthite contents do not show a distinct decrease and reasons for this behaviour are currently unclear. $\mathrm{Ca}-\mathrm{Na}$ ratios between plagioclase and residual melt and $\mathrm{K}_{\mathrm{D}}$ trajectories are illustrated in Fig. 11b. It is evident that each explored fractionation path exhibits a strong dependence of $\mathrm{Ca}-\mathrm{Na}$ distribution coefficients on experimental temperature. At high temperatures $\left(\geq 1020^{\circ} \mathrm{C}\right) \mathrm{K}_{\mathrm{D}}$ 's scatter around 3.0-4.0 but evolve to higher values (4.0-5.5) with cooling finally reaching a range of 5.5 to 7.0 at lowest temperatures. Sisson and Grove (1993a) showed that water content (and/or water activity) exerts a

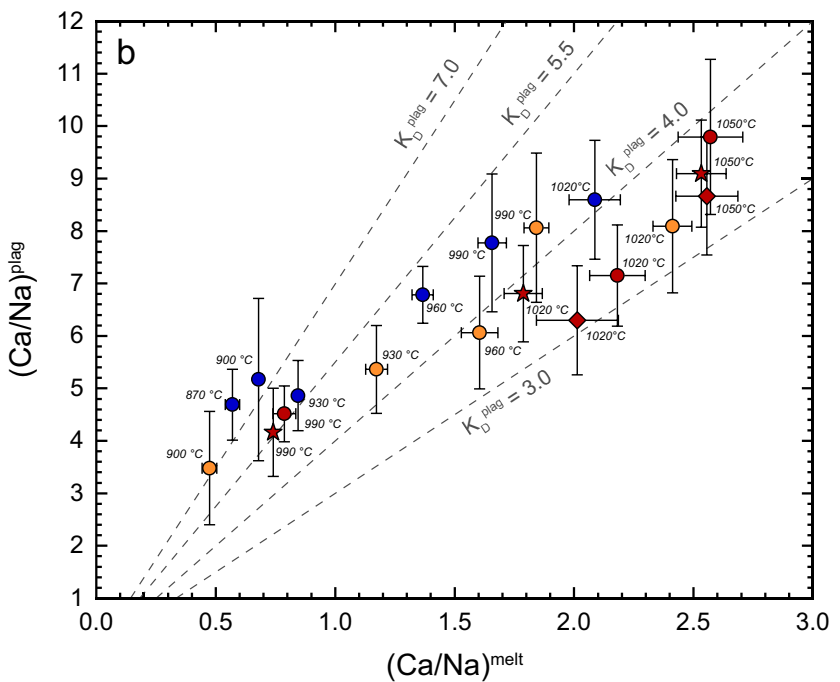

are drawn for comparison. Error bars are not shown in case their extent is smaller than the symbol size

strong influence on $\mathrm{Ca}-\mathrm{Na}$ distribution coefficients reaching maximum $\mathrm{Ca}-\mathrm{Na} \mathrm{K}_{\mathrm{D}}$ values of about 5.5 at water-saturation at $0.2 \mathrm{GPa}$. These findings agree with our data documenting progressively increasing water contents (and water activities) upon differentiation.

\section{Fe-Ti-oxides}

Spinel group minerals exhibit a strong compositional dependence on temperature, where hercynitic spinel crystallised at high temperatures $\left(1020-1050{ }^{\circ} \mathrm{C}\right)$, titanomagnetite formed at intermediate temperatures $\left(930-960{ }^{\circ} \mathrm{C}\right)$, and Ti-bearing magnetite was stable at low temperatures $\left(900-930^{\circ} \mathrm{C}\right)$. This transition in spinel composition corresponds to the onset of ferric iron incorporation in the spinel structure at the expense of Al. Spinel group minerals of the hot oxidised path exhibit elevated ferric iron contents and diminished Ti concentrations compared to spinel from the other series because of the higher $\mathrm{fO}_{2}$ of these experiments. Ilmenite crystallised along the cold path and coexists with magnetite at $960{ }^{\circ} \mathrm{C}$ and $0.6 \mathrm{GPa}$, but represents the only stable $\mathrm{Fe}-\mathrm{Ti}$-oxide in the two lowest temperature runs ( 900 and $870{ }^{\circ} \mathrm{C}$ ). Generally, $\mathrm{MgO}$ contents of experimental ilmenite are minor (4.03-5.00 wt.\%), and recalculated ferric iron contents range from 0.09 to 0.18 a.p.f.u.

\section{Minor phases}

Biotite was only stable in the lowest temperature run of the cold path $\left(870{ }^{\circ} \mathrm{C}\right.$ and $\left.0.4 \mathrm{GPa}\right)$ with an $\mathrm{xMg}$ of 0.70 , an average $\mathrm{TiO}_{2}$ content of $3.87 \mathrm{wt} . \%$, and minor amounts of $\mathrm{Na}_{2} \mathrm{O}$ (1.10 wt.\%). Similarly, orthopyroxene was only 
observed in the lowest temperature run of the intermediate path and exhibits weak sector zonation most pronounced in alumina and iron contents. The xMg's of 0.72 (high-Al sector, 2.63 wt. $\% \mathrm{Al}_{2} \mathrm{O}_{3}$ ) and 0.69 (low-Al sector, 1.55 wt.\% $\mathrm{Al}_{2} \mathrm{O}_{3}$ ) identify these orthopyroxenes as hypersthene. $\mathrm{MnO}$ contents are rather high with 2.43 wt.\% (high-Al) and 2.95 wt.\% (low-Al).

\section{Discussion}

\section{Comparison of experimental liquid lines of descent with Cascades volcanic rocks}

First, we compare the experimentally derived liquid lines of descent (LLD) with a compilation of bulk rock data from the Cascades volcanics in the Western U.S. (Du Bray et al. 2006) and with previous isobaric fractional and equilibrium crystallisation experiments. Since our polybaric fractionation series were terminated when residual liquids reached andesitic to dacitic compositions, more evolved (rhyolitic) compositions exhibited by the natural rocks were not reproduced. However, differentiation trends of intermediate and more evolved magmas are controlled by multicomponent phase equilibria and follow well-defined compositional trajectories as established by previous experimental studies (e.g. Grove and Baker 1984; Sisson and Grove 1993a; Blatter et al. 2017; Müntener and Ulmer 2018; Ulmer et al. 2018; Marxer and Ulmer 2019). It has to be emphasised that comparisons between experimental LLD's and natural rocks assume that the latter represent true liquid compositions, which is not entirely true for most cases and, thus, has to be kept in mind for the following discussion.

Overall, LLD's of our polybaric fractionation series as well as previous experimental trends from the literature only partly overlap with the differentiation trends defined by the Cascades volcanic rocks. Due to the near-linear relationship with experimental temperature (Fig. 7f), we chose $\mathrm{MgO}$ to illustrate experimental and natural differentiation trends. Silica contents of the polybaric LLD's define a nonlinear increase with decreasing $\mathrm{MgO}$ similar to the Cascades rocks, with an excellent overlap at low $\mathrm{MgO}(\leq 3-4$ wt.\%) for the last fractionation steps of each polybaric series (Fig. 12a). At less evolved stages, residual melts plot at the lower end of the field delineated by natural rocks. One possible reason is the low $\mathrm{SiO}_{2}$ of our starting material $\left(\mathrm{SiO}_{2}\right.$ of $\left.47.4 \mathrm{wt} . \%\right)$. Primitive rocks from the Cascades volcanoes, however, are generally more enriched in silica. Furthermore, for any specific $\mathrm{MgO}$ content, LLD's defined by previous experimental studies plot at the lower end of natural rocks delineated by the Cascades, but generally above our own data. However, the differentiation trend of Nandedkar et al. 2014; reproduces well the natural spread, which could be related to the more silicic character of their starting material and the slightly lower initial water content favouring the attainment of a higher melt silica activity.

$\mathrm{TiO}_{2}$ contents of experimental melts agree well with the natural rock compositions but essentially only reproduced the lower range of natural titanium contents (Fig. 12b). The elevated $\mathrm{TiO}_{2}$ concentrations of some Cascades rocks can be explained by compositional variations of primary mantlederived magmas, where high $\mathrm{TiO}_{2}$ rocks represent $\mathrm{H}_{2} \mathrm{O}$-poor decompression melts (i.e. high-alumina olivine tholeiites) (e.g. Bartels et al. 1991; Grove et al. 2002), while rocks with lower $\mathrm{TiO}_{2}$ contents correspond to subduction related magmas produced by fluid flux-melting of mantle rocks (e.g. Grove et al. 2002, 2005). Fractional crystallisation LLD's at 0.7-1.0 GPa (Nandedkar et al. 2014; Ulmer et al. 2018) also reproduce the natural differentiation trend albeit at lower maximum $\mathrm{TiO}_{2}$ compared to polybaric fractionation. This can be related to the efficient depletion of residual melts in titanium due to enhanced amphibole fractionation at higher pressures and/or slightly higher $\mathrm{fO}_{2}(\mathrm{NNO}$ to $\mathrm{NNO}+1)$ favouring earlier saturation of $\mathrm{Fe}-\mathrm{Ti}$-oxides. The effect of amphibole fractionation on melt $\mathrm{TiO}_{2}$ contents is also shown by the LLD at $0.4 \mathrm{GPa}$ of Nandedkar (2014), where amphibole and $\mathrm{Fe}-\mathrm{Ti}$-oxide crystallisation was not observed resulting in an enrichment of the residual melts in $\mathrm{TiO}_{2}$. The LLD's by Blatter et al. (2013), albeit starting at higher $\mathrm{TiO}_{2}$ contents, reveal a similar evolution, where the onset of $\mathrm{TiO}_{2}$ decrease is almost pressure independent and agrees well with our polybaric data.

Experimental liquids are enriched in $\mathrm{Al}_{2} \mathrm{O}_{3}$ with respect to the Cascades rocks (Fig. 12c). This is related to the combined effects of suppressed crystallisation of plagioclase at high pressures $(0.6-0.8 \mathrm{GPa})$ and the elevated $\mathrm{Al}_{2} \mathrm{O}_{3}$ contents of our primary starting materials (Table 1). This indicates that a majority of the Cascades volcanics did not fractionate exclusively in the lower crust, as rocks with comparable $\mathrm{MgO}$ concentrations reveal distinctly lower $\mathrm{Al}_{2} \mathrm{O}_{3}$ contents than the experimental LLD's. Decompression of ascending magmas enhances plagioclase crystallisation, resulting in a decrease of $\mathrm{Al}_{2} \mathrm{O}_{3}$ of experimental liquids following compositional trends of the natural rocks. In fact, only residual liquids of the last decompression steps to 0.2 GPa for the hot, hot oxidised, and intermediate path plot within the Cascades range, while the cold path remains at too high $\mathrm{Al}_{2} \mathrm{O}_{3}$ contents due to pronounced fractionation at higher pressures. Isobaric differentiation trends between 0.7 and 1.0 GPa (Blatter et al. 2013; Nandedkar et al. 2014; Ulmer et al. 2018) closely follow our polybaric fractionation trends and likewise overestimate $\mathrm{Al}_{2} \mathrm{O}_{3}$ contents with respect to the natural rocks. Only the 0.4 GPa LLD's reproduce the natural differentiation trend (Blatter et al. 2013; Nandedkar 2014) illustrating the effect of pressure on $\mathrm{Al}_{2} \mathrm{O}_{3}$ contents of residual liquids. 

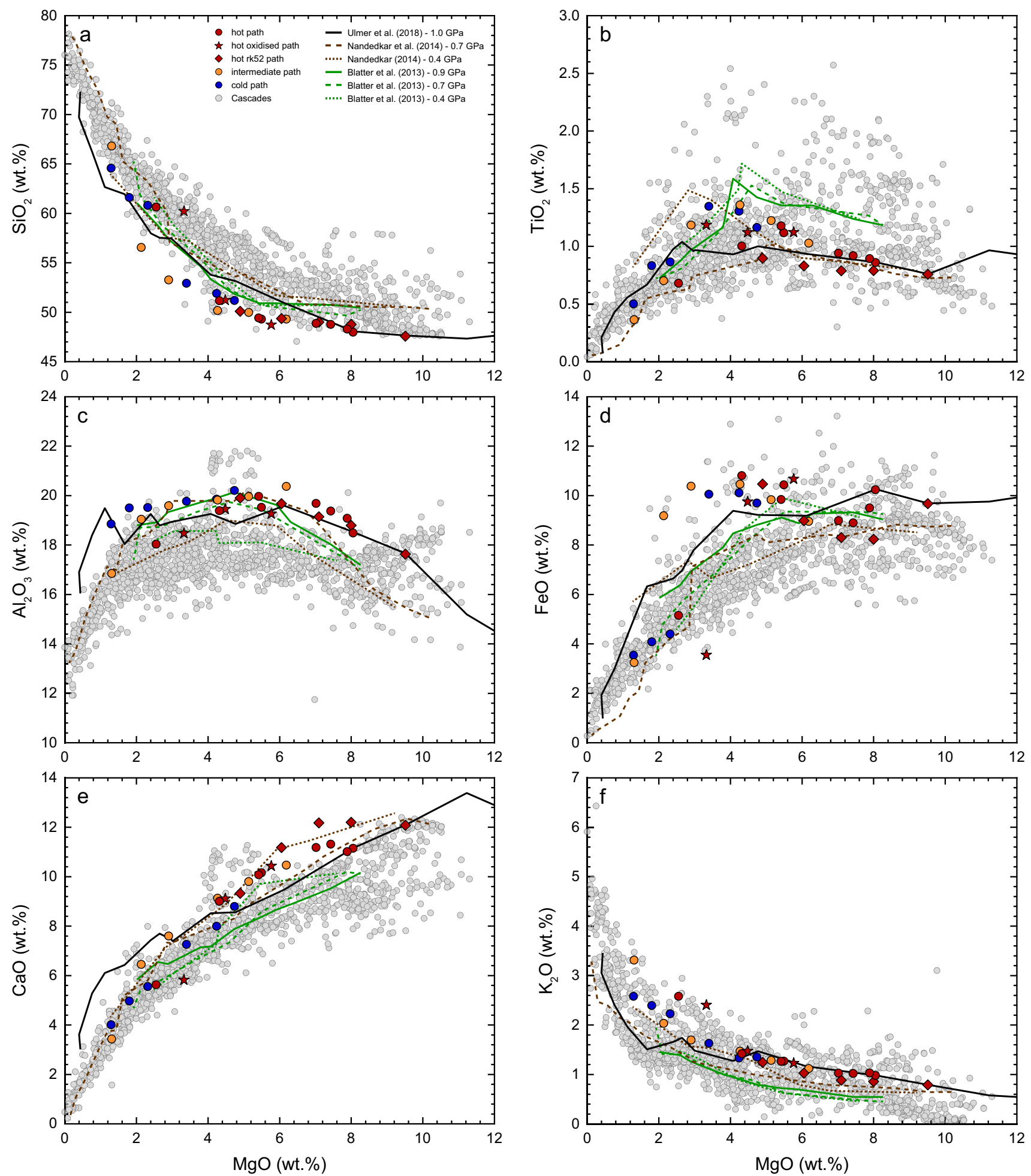

Fig. 12 Major oxide variation diagrams comparing polybaric liquid lines of descent of this study with natural bulk rock compositions from the Cascades volcanics (Du Bray et al. 2006). In addition, magma differentiation trends from a selection of previous experimen-

tal studies (Nandedkar et al. (2014) (0.7 GPa), Nandedkar 2014 (0.4 GPa), Ulmer et al. (2018) (1.0 GPa), and Blatter et al. (2013) (0.4, 0.7 , and $0.9 \mathrm{GPa})$ ) are illustrated with coloured lines. For further explanations, see text 

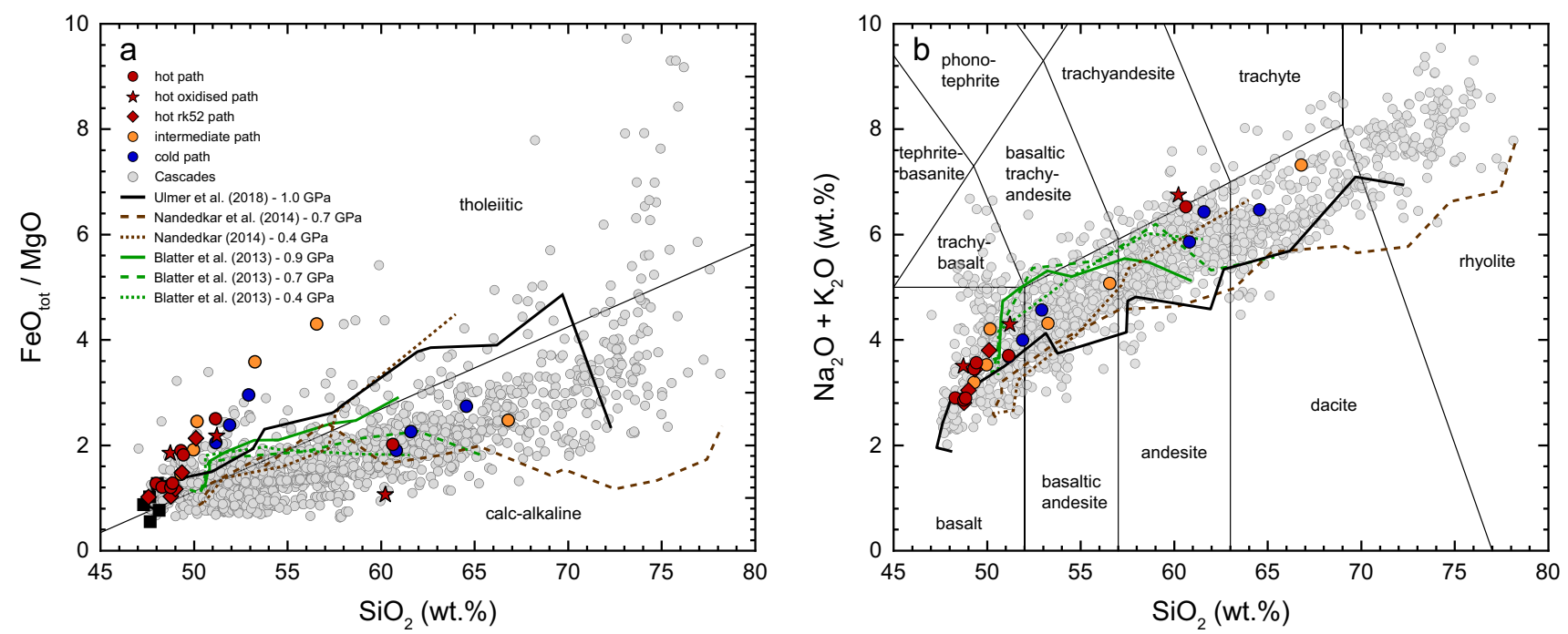

Fig. $13 \mathrm{FeO}_{\text {tot }} / \mathrm{MgO}$ (a) and total alkalis $\left(\mathrm{Na}_{2} \mathrm{O}+\mathrm{K}_{2} \mathrm{O}\right)$ (b) plotted against $\mathrm{SiO}_{2}$ (in wt.\%) comparing polybaric fractionation trends with natural data from the Cascades and liquid lines of descent of previous experimental studies

Our fractionation experiments overestimate iron contents (Fig. 12d) with respect to the natural rock record at intermediate stages of differentiation (2-6 wt.\% MgO). This could be related to delayed saturation of $\mathrm{Fe}-\mathrm{Ti}$-oxides as a consequence of slightly lower $\mathrm{fO}_{2}$ of our experiments compared to the natural rock record. In contrast, the most evolved run of the hot oxidising path plots at too low $\mathrm{FeO}$ contents inferring that $\mathrm{fO}_{2}$ conditions close to $\mathrm{RRO}$ put an upper bound on magmatic redox conditions. This interpretation is supported by experiments at more oxidising conditions, which better reproduce the natural rock record (NNO to $\mathrm{NNO}+1$ for Nandedkar (2014), Nandedkar et al. (2014), and Ulmer et al. (2018) or RRO-0.5 to RRO+1.3 for Blatter et al. (2013)).

$\mathrm{CaO}$ characteristics (Fig. 12e) of the polybaric fractionation paths are shifted towards higher values at intermediate (5-10 wt.\%) $\mathrm{MgO}$ contents. Only upon the last fractionation steps, our data overlap with the natural rock record. This can be explained by higher $\mathrm{CaO}$ contents of our starting material compared to the Cascades volcanics. This interpretation is supported by previous experiments on related starting compositions from the Adamello which overlap with our data and also plot at too high $\mathrm{CaO}$ concentrations (Fig. 12e). However, LLD's established by Blatter et al. (2013) almost perfectly reproduce the Cascades trend indicating that $\mathrm{CaO}$ trajectories are dominantly controlled by the primary magma composition and less by the initial stages of differentiation.

$\mathrm{K}_{2} \mathrm{O}$ evolution trends closely reproduce the natural trend exhibited by the Cascades rocks (Fig. 12f), mostly covering the upper end of potassium concentrations. The last fractionation experiments of the hot, hot oxidised, and intermediate path plot at the upper boundary of the natural compositions. This is related to the incompatible behaviour of potassium in calc-alkaline systems and a slightly elevated $\mathrm{K}_{2} \mathrm{O}$ content of our primary starting material. Residual liquids of the equilibrium and fractional crystallisation experiments plot at slightly lower potassium contents but show a similar characteristic enrichment in $\mathrm{K}_{2} \mathrm{O}$ upon decreasing $\mathrm{MgO}$ (Fig. 12f).

Figure $13 \mathrm{a}$ presents $\mathrm{FeO}_{\text {tot }} / \mathrm{MgO}$ ratios (all iron as $\mathrm{FeO}$ ) as a function of $\mathrm{SiO}_{2}$ content of residual melts to distinguish tholeiitic from calc-alkaline differentiation trends (Miyashiro 1974). Residual liquids from previous experimental series follow the boundary between the tholeiitic and calc-alkaline field during early stages of differentiation but enter the latter upon advanced crystallisation. Our data reveal a distinct excursion towards tholeiitic compositions with increasing $\mathrm{SiO}_{2}$ followed by a back-bend into the calcalkaline field related to $\mathrm{Fe}-\mathrm{Ti}$-oxide crystallisation. On the contrary, the $0.7 \mathrm{GPa}$ differentiation trends display only a weak initial enrichment in iron and become calc-alkaline between 55 and 60 wt.\% of $\mathrm{SiO}_{2}$. The variations in $\mathrm{FeO}_{\text {tot }} /$ $\mathrm{MgO}$ among different experimental series is controlled by $\mathrm{fO}_{2}$ during differentiation as discussed in detail by Sisson et al. (2005). The combined effects of low $\mathrm{fO}_{2}$ and low $\mathrm{H}_{2} \mathrm{O}$ contents result in delayed crystallisation of $\mathrm{Fe}-\mathrm{Ti}-$ oxides, driving residual liquids into the tholeiitic field, while calcalkaline trajectories are favoured by more hydrous and oxidising conditions (e.g. Sisson et al. 2005; Blatter et al. 2013; Nandedkar et al. 2014).

In the TAS diagram $\left(\mathrm{SiO}_{2}\right.$ vs $\left.\mathrm{Na}_{2} \mathrm{O}+\mathrm{K}_{2} \mathrm{O}\right)$ the experimental series reproduce the natural differentiation trend (Fig. 13b). However, the high-pressure LLD's at 0.7 and $1.0 \mathrm{GPa}$ evolve along the lower limit of the natural compositional field and reach rhyolitic compositions, while the polybaric trends rather plot at the upper end and only extend 


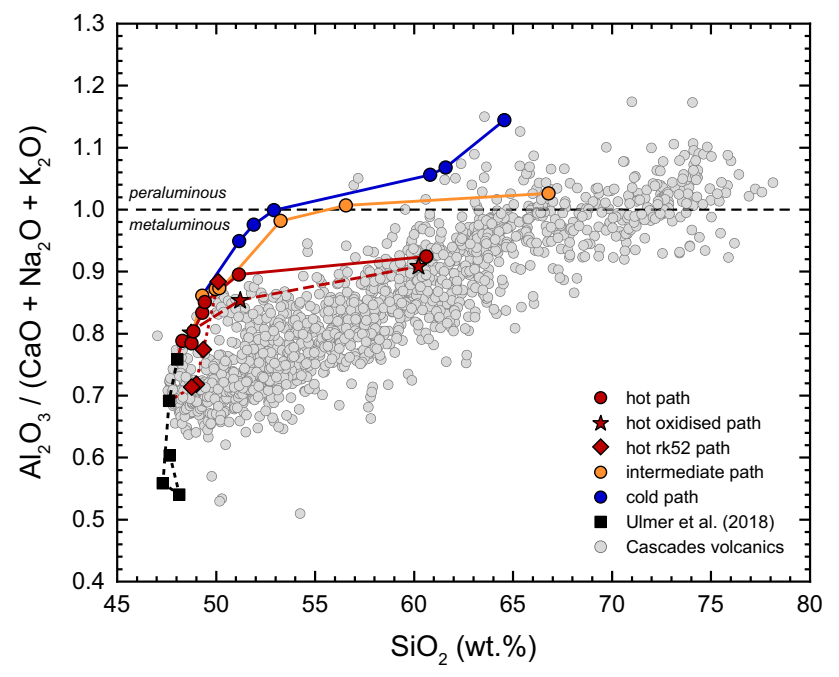

Fig. 14 Alumina saturation index (ASI, molar ratio of $\mathrm{Al}_{2} \mathrm{O}_{3}$ / $\left.\left(\mathrm{CaO}+\mathrm{Na}_{2} \mathrm{O}+\mathrm{K}_{2} \mathrm{O}\right)\right)$ of experimental residual liquids and natural rocks from the Cascades volcanoes plotted against silica contents (in wt.\%). Major oxide compositions of experimental liquids as well as natural data were renormalised to $100 \mathrm{wt}$ \% for plotting

into the andesite or dacite field. These differences in TAS trajectories are related to variations in $\mathrm{Na}_{2} \mathrm{O}$ and $\mathrm{K}_{2} \mathrm{O}$ contents of the different starting materials (e.g. potassium) and/ or variable phase equilibria (e.g. stability fields of plagioclase and amphibole).

In summary, a detailed comparison of our experimental data and previous studies with the natural rock record from the Cascades reveals that polybaric fractional crystallisation only partly reproduces the chemical variability of arc rocks. Differences for some oxides (e.g. $\mathrm{K}_{2} \mathrm{O}$ or $\mathrm{SiO}_{2}$ ) can be explained by variations in the experimental starting materials while others are related to the redox conditions during differentiation (e.g. $\mathrm{FeO}$ and $\mathrm{FeO}_{\mathrm{tot}} / \mathrm{MgO}$ ). Distinct differences among other components, such as $\mathrm{Al}_{2} \mathrm{O}_{3}$, are controlled by phase equilibria, i.e. the fractionation of clinopyroxene during early stages of differentiation at high pressures and the simultaneous suppression of plagioclase crystallisation. The compositional spread revealed by natural calc-alkaline rock suites requires additional magmatic processes besides polybaric fractionation, such as imperfect fractionation (i.e. crystal entrainment during melt extraction), magma mixing (e.g. Sisson et al. 2005; Reubi and Blundy 2009; Blatter et al. 2013), or crustal assimilation (e.g. DePaolo 1981; Hildreth and Moorbath 1988) and is addressed in the last section of the discussion.

\section{Evolution of the alumina saturation index}

Evolution trajectories of the alumina saturation index (ASI, molar ratio of $\left.\mathrm{Al}_{2} \mathrm{O}_{3} /\left(\mathrm{CaO}+\mathrm{Na}_{2} \mathrm{O}+\mathrm{K}_{2} \mathrm{O}\right)\right)$ of experimental liquids are compared with volcanic rocks from the Cascades and the $1.0 \mathrm{GPa}$ fractionation experiments of Ulmer et al. (2018) preceding the polybaric series (Fig. 14). Natural rocks follow a differentiation trend from metaluminous (ASI $<1$ ) towards weakly peraluminous (ASI $>1$ ) compositions. In contrast, our polybaric LLD's differ significantly and plot at elevated ASI's. Most remarkably, the coolingdominated fractionation trends (cold and intermediate path) rapidly evolve towards peraluminous compositions and become corundum-normative at silica contents between 48 and $52 \mathrm{wt} . \%$. In contrast, the decompression-dominated fractionation trends (hot and hot oxidised path) remain metaluminous during differentiation and enter the compositional field covered by the natural rocks upon final decompression to $0.2 \mathrm{GPa}$. This difference between different polybaric fractionation series is directly related to the effect of pressure on phase equilibria. At high pressures (0.6-0.8 GPa), extensive clinopyroxene crystallisation results in a pronounced depletion of residual melts in $\mathrm{CaO}$. Such an evolution towards andesitic or dacitic peraluminous differentiates at high pressures has previously been reported by experimental studies (e.g. Blatter et al. 2013; Nandedkar et al. 2014; Ulmer et al. 2018). Upon decompression to 0.4-0.2 GPa, clinopyroxene and amphibole destabilise at the expense of olivine and plagioclase keeping residual liquids metaluminous. Consequently, decompression-dominated fractionation trends better reproduce the natural compositional range.

\section{Phase relations and liquid lines of descent in pseudoternary projections}

Compositions of residual experimental liquids and the Cascades volcanics are plotted in the normative olivine $(\mathrm{Ol})$ - clinopyroxene $(\mathrm{Cpx})-$ quartz + orthoclase $(\mathrm{Qtz}+\mathrm{Or})$ pseudoternary diagram projected from plagioclase (Plag), apatite (Ap), and ilmenite-hematite (Ilm-Hem) to illustrate the control of phase equilibria on the LLD's (Fig. 15). Normative mineral compounds were re-calculated from melt compositions following the approach presented by Grove et al. (1992) and modified by Blatter et al. (2017). To facilitate the interpretation of LLD's, we additionally plotted bulk compositions of experimental cumulates (highlighted by the grey shaded background). Cumulate compositions were calculated based on phase proportions (Table 2) and average compositions of mineral phases (Table 3) and are reported in the Electronic Supplementary Material ESM 7. For normative calculations, ferric/ferrous iron ratios of residual melts were estimated as follows: For runs buffered close to NNO (hot, hot rk52, intermediate, and cold path), an $\mathrm{Fe}^{3+} / \mathrm{Fe}_{\text {tot }}$ ratio of 0.20 was assumed based on results from the Kress and Carmichael (1991) algorithm. Accordingly, a value of 0.35 was employed for the hot oxidised path. For the Cascades volcanics we assumed a ratio of 0.20 inferring that 


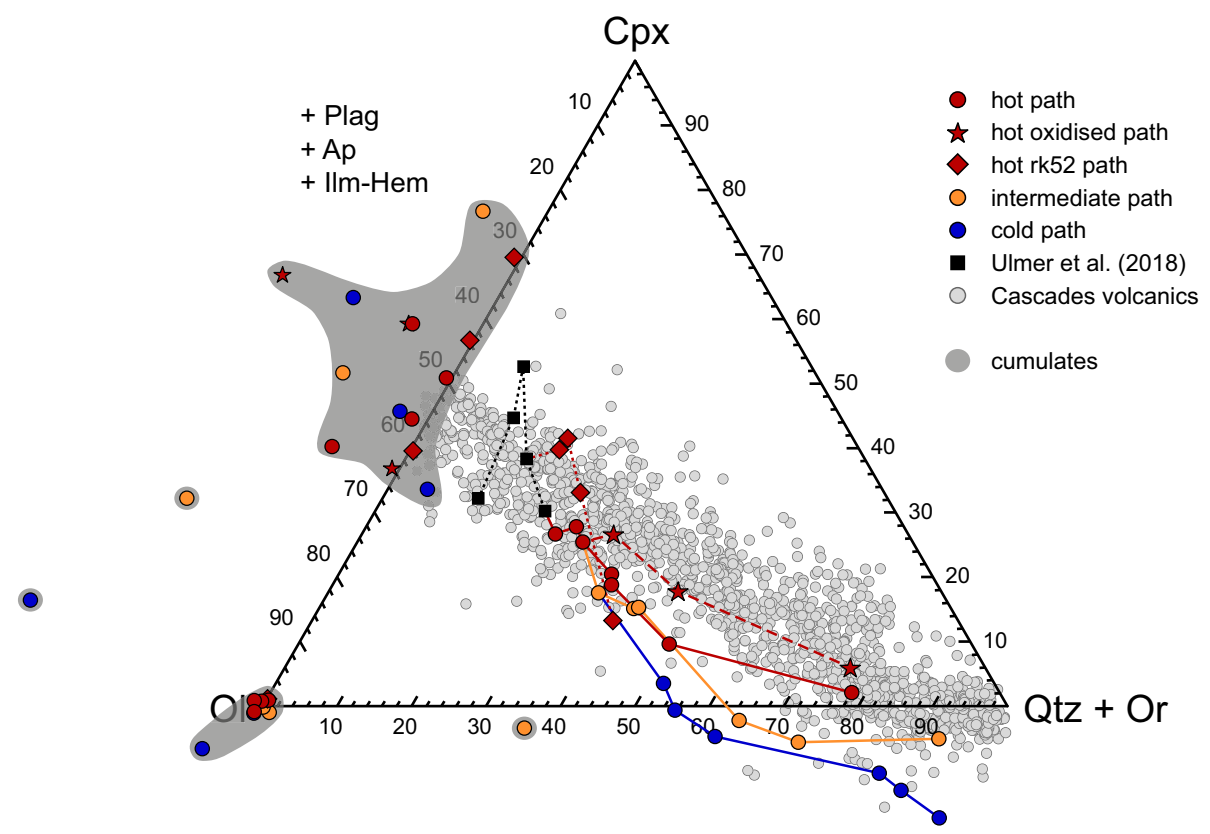

Fig. 15 Experimental liquid lines of descent and natural rock compositions from the Cascades volcanoes plotted in the normative pseudoternary olivine (Ol)-clinopyroxene (Cpx)-quartz + orthoclase (Qtz+Or) diagram projected from plagioclase (Plag), apatite (Ap), and ilmenite-hematite (Ilm-Hem). Residual liquid compositions of the first crystallisation steps from the preceding isobaric fractionation

these rocks predominantly formed at moderately oxidising $\mathrm{fO}_{2}$ conditions.

All five LLD's exhibit a continuous decrease of normative clinopyroxene and olivine accompanied by an enrichment in quartz + orthoclase, illustrated by the differentiation trends away from the Ol-Cpx side-line towards the Qtz + Or corner. These trends are consistent with extensive crystallisation of $\mathrm{Fe}-\mathrm{Mg}$ silicates with ongoing cooling (Figs. 7 and 12). Differentiation trajectories can roughly be distinguished in three intervals: an initial phase characterised by olivine fractionation resulting in an increase or stagnation of the clinopyroxene component, followed by a second interval dominated by clinopyroxene and olivine cotectic crystallisation depleting residual liquids efficiently in normative clinopyroxene, and a final interval, where the crystallisation of amphibole and magnetite leads to a pronounced enrichment of residual melts in $\mathrm{SiO}_{2}$ shifting the trajectories towards the Qtz + Or corner. Such differentiation trends are a characteristic feature of calc-alkaline differentiation, as previously shown by numerous studies (Sisson and Grove 1993a; Pichavant and Macdonald 2007; Nandedkar et al. 2014; Ulmer et al. 2018). Experimental cumulates define two main groups. The first one lies close to the $\mathrm{Ol}$ apex and represents dunitic or troctolitic cumulates. The second group plots close to the Qtz + Or base-line at similar normative Ol and Cpx contents and either represents clinopyroxene- or study by Ulmer et al. (2018) at $1.0 \mathrm{GPa}$ are illustrated with the black squares. Calculated bulk compositions of experimental cumulates are plotted for comparison and highlighted with a dark-grey shaded background. For more details on projection procedure and data treatment, see text and the Electronic Supplementary Material ESM 7

amphibole-dominated cumulates. In detail, amphibole-bearing cumulates are shifted towards more negative Qtz + Or (due to nepheline-normative amphibole) while clinopyroxene-dominated ones are displaced to slightly higher Cpx.

During early stages of fractionation, melt compositions from the hot, intermediate, and cold path are similar, with an enhanced decrease of the clinopyroxene component accompanied by a less distinct reduction of the olivine compound. Subsequently, the hot path diverges from the more cooling-dominated intermediate and cold LLD's. The latter two trajectories continue their evolution towards the $\mathrm{Cpx}$ base-line, while the hot path bends towards the Qtz + Or corner as a consequence of enhanced olivine crystallisation and destabilisation of clinopyroxene, keeping residual melts metaluminous. Crystallisation of clinopyroxene and amphibole drives the cooling-dominated fractionation trends into the peraluminous compositional field. The intermediate path exhibits extensive orthopyroxene and magnetite fractionation in the last step directing residual liquids towards the Qtz + Or corner, while the LLD defined by the cold path is controlled by amphibole fractionation and evolves deeper into the peraluminous field. The hot rk52 path was explored to test if an elevated clinopyroxene component of the initial basaltic magma results in an LLD subparallel to the previous FC paths (hot, intermediate, or cold), but displaced to higher normative clinopyroxene. This was, however, not the case; it 
converges with the other series originating from the starting material rk54 upon the last temperature step investigated. Thus, starting crystallisation from a more Cpx-rich initial composition just results in higher proportions of early clinopyroxene fractionation but has no effect on the later stage chemical evolution of the residual liquids. In contrast, the hot oxidised path branches off from the hot path at $1080^{\circ} \mathrm{C}$ and $0.8 \mathrm{GPa}$ and evolves along a trajectory subparallel to the LLD's of the other fractionation series but maintains higher normative clinopyroxene components, underlining the important control of $\mathrm{fO}_{2}$ on crystallisation-differentiation.

In principle, the exact location of the olivine-clinopyroxene cotectic curve controlling the LLD of arc magmas depends on pressure, $\mathrm{fO}_{2}$, and bulk system composition (i.e. $\mathrm{xMg}$ ). The olivine-clinopyroxene cotectic is shifted towards clinopyroxene-rich compositions with decreasing pressure (i.e. polybaric fractionation) leading to a destabilisation of clinopyroxene at the expense of olivine (e.g. Grove et al. 1992; Hamada and Fujii 2008; Stamper et al. 2014; Melekhova et al. 2015) and a displacement of LLD's towards the Cpx apex. Consequently, cooling-dominated polybaric fractionation (cold path) exhibits an evolution towards strongly peraluminous compositions, while the LLD of decompression-dominated one (hot path) plots at higher normative clinopyroxene and remains in the metaluminous field. The intermediate path lies between these two endmembers, but also becomes weakly peraluminous upon progressive differentiation. An increase of $\mathrm{fO}_{2}$ leads to the destabilisation of clinopyroxene at the expense of olivine. This effect is linked to the ferrous iron content of the crystallising magma. An increase of $\mathrm{fO}_{2}$ results in reduced proportions of $\mathrm{FeO}$ in the melt at the expense of $\mathrm{Fe}_{2} \mathrm{O}_{3}$ and an increase of the effective $\mathrm{xMg}\left(=\mathrm{Mg} /\left(\mathrm{Mg}+\mathrm{Fe}^{2+}\right)\right)$ of the residual melt favouring olivine over clinopyroxene (e.g. Ulmer et al. 2018). In fact, the hot oxidised path at $\mathrm{RRO}$ exemplifies this influence of $\mathrm{fO}_{2}$ on the olivine-clinopyroxene cotectic, which is displaced towards higher normative Cpx component relative to NNO. In addition, elevated $\mathrm{fO}_{2}$ conditions promoted crystallisation of spinel phases, further enhancing $\mathrm{SiO}_{2}$ enrichment and $\mathrm{FeO}$ decrease of residual melts.

The comparison of the experimental LLD's with compositions of the Cascades volcanics reveals that polybaric differentiation cannot completely reproduce the natural rock record. The depletion of residual liquids in normative clinopyroxene contents along the cold and intermediate path drives them below the natural rock record into the peraluminous field. However, the intermediate path experiences a pronounced shift towards the quartz + orthoclase corner during the last differentiation step (fractionation of $\mathrm{Fe}-\mathrm{Ti}$-oxide bearing norites) resulting in an overlap with the natural rock record for weakly peraluminous compositions. The LLD of the hot path is slightly shifted towards higher normative clinopyroxene and follows the lower limit of the natural rocks overlapping in the last fractionation step with metaluminous intermediate to more evolved natural rocks. The hot oxidised path follows higher normative clinopyroxene contents overlapping with the Cascades volcanics.

Consequently, decompression-dominated magma ascent paths closely overlap with natural volcanic rocks, while cooling-dominated ascent trajectories deviate significantly. The present data emphasise the possible importance of $\mathrm{fO}_{2}$ of silicate magmas on LLD's: only the hot oxidised path is able to reproduce the compositional trend of volcanic rocks inferring that redox conditions of fractionating arc magmas are, in fact, about one log-unit higher (NNO+1 to NNO+2) than commonly assumed (NNO to NNO+1) (e.g. Gill 1981; Cottrell et al. 2021).

\section{General implications for arc magma differentiation}

Our experiments show that decompression-dominated polybaric fractionation represents a possible scenario for arc magma differentiation, although the applicability of this model exhibits some limitations. Consequently, additional (open-system) magmatic processes and/or different near-adiabatic decompression paths with variable initial temperature need to be considered to derive a general model for arc magmatism able to explain the observed compositional variation of natural calc-alkaline rocks.

One process is mixing of melts with different compositions (i.e. basaltic and dacitic to rhyolitic) in the lower crust (e.g. Hildreth and Moorbath 1988). Thereby, the evolved magmas either represent differentiation products of basaltic magmas originating from the underlying mantle or lowdegree partial melts from previously solidified basaltic magmas re-melted by heat supply of freshly injected primitive melts. After mixing, these buoyant metaluminous intermediates start ascending towards the upper crust and further differentiate via polybaric fractionation. In fact, rocks from the Cascades exhibit broadly linear trajectories for several chemical parameters (Figs. 12, 13, and 15) between compositions from evolved basalt ( $~ 8 \mathrm{wt} . \% \mathrm{MgO})$ to andesite/dacite $(\sim 2 \mathrm{wt} . \% \mathrm{MgO})$. However, primitive rocks do not match these linear trends pointing towards early crystallisationdifferentiation of primary mantle-derived basalts. Likewise, more evolved rhyodacitic to rhyolitic compositions do not represent extrapolations of the linear intermediate trajectories. This observation indicates that the late stage chemical evolution of residual liquids is, again, dominated by crystallisation processes. The distinct rheology contrast between mafic and felsic magmas is severely hampering any efficient mixing of strongly contrasting compositions and favouring magma mingling instead (e.g. Eichelberger 1975; Sparks and Marshall 1986; Blundy and Sparks 1992). However, in case of mixing components being close in composition and temperature (i.e. evolved basalt and andesite) this difference 
Fig. 16 Schematic sketch illustrating a general model for arc magma differentiation proposed in this study. For mineral abbreviations, see captions of Figs. 3 and 5. At lower crustal pressures, mantlederived magmas fractionate and derivative evolved basalts mix to some extent with intermediate liquids. During subsequent extraction from the lower crust, significant proportions of crystals are entrained (=imperfect fractional crystallisation). Upon ascent, these magmas continue to differentiate via polybaric fractionation accompanied by dissolution of clinopyroxene and the stabilisation of olivine and plagioclase. Finally, magmas either stall at shallow levels and solidify to upper crustal batholiths of intermediate to more evolved bulk composition or erupt at the surface

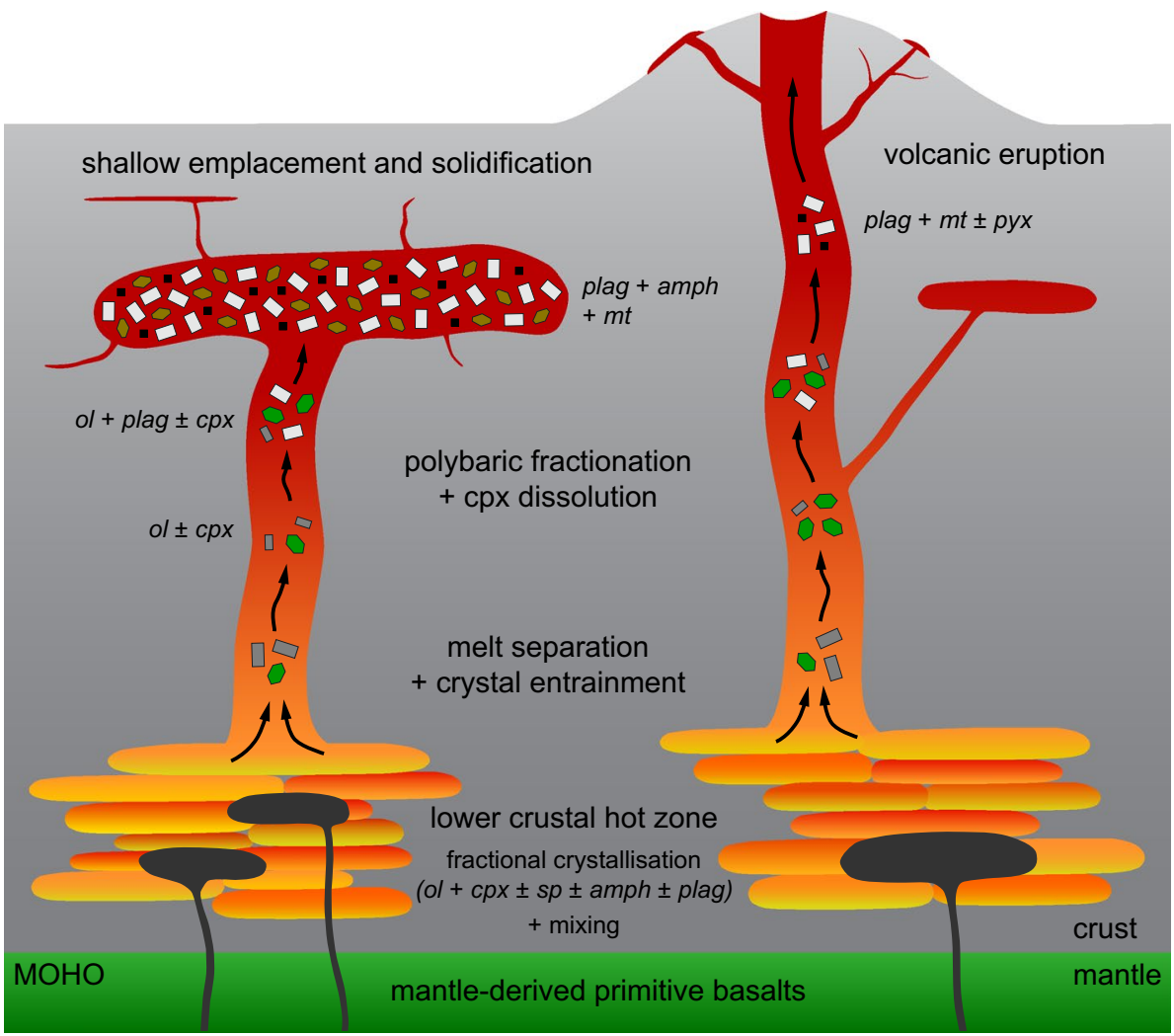

in rheology also diminishes potentially facilitating the mixing process.

A second, potentially even more important, mechanism is incomplete fractionation and crystal retention in decompressing magmas. Early fractionation of primitive basalt at the crust-mantle boundary is dominated by the crystallisation of olivine, clinopyroxene, and very minor Cr-rich spinel resulting in wherlite and olivine-clinopyroxenite cumulates. Derivative buoyant residual magmas rising towards the upper crust may contain significant proportions of this clinopyroxene-dominated crystal cargo. Upon ascent and decompression, the olivine-clinopyroxene cotectic shifts towards clinopyroxene by dissolving entrained clinopyroxene, while olivine remains stable and/or continues to crystallise/fractionate. Consequently, normative clinopyroxene contents of the ascending magma increase driving it towards the compositional range covered by natural rocks (Fig. 15).

In summary, we infer that the compositional variation revealed by natural calc-alkaline rocks can be reproduced by a combination of polybaric fractionation, mixing of magmas of differentiated basaltic and andesitic/dacitic composition, and the entrainment of clinopyroxene upon melt extraction in the lower crust. A conceptual model illustrating the various processes of arc magma differentiation is shown in Fig. 16. Hydrous mantle-derived primitive basalts fractionate olivine + clinopyroxene \pm spinel, and minor amounts of plagioclase and amphibole in the lower crust. This fractionation process is accompanied by mixing between evolved basaltic and andesitic/dacitic magmas. Clinopyroxene and olivinedominated cumulate assemblages are potentially entrained due to imperfect fractionation processes in the lower crust. During decompression and magma ascent, residual liquids further evolve via polybaric fractionation of olivine, plagioclase, and magnetite and by dissolution or minor crystallisation of clinopyroxene. In addition, differentiation during ascent is potentially accompanied by mixing/mingling of compositionally similar magma batches in the conduit. Finally, resulting evolved magmas are either emplaced in the upper crust and solidify to intermediate/felsic plutonic rocks or erupt on the surface building arc volcanic complexes.

\section{Conclusions}

This experimental study explored the scenario of polybaric fractional crystallisation of arc magmas and tested its applicability to explain the compositional variation of natural calc-alkaline rocks at convergent plate margins. A total of five different magma ascent paths were explored to investigate the combined effects of cooling and decompression, $\mathrm{fO}_{2}$, and the composition of the initial starting material on the resultant liquid lines of descent. The most relevant findings of this study are: 
- During polybaric fractionation, decompression causes continuous changes in phase equilibria controlling the LLD's. With decreasing pressure, clinopyroxene is destabilised at the expense of olivine resulting in a shift of the olivine-clinopyroxene cotectic curve towards more clinopyroxene normative compositions. The stability field of plagioclase expands with decreasing pressure, with important effects on $\mathrm{Al}_{2} \mathrm{O}_{3}$ contents of derivative liquids. Amphibole crystallisation was restricted to elevated pressures of $0.4-0.6 \mathrm{GPa}$, but absent in the lowest pressure runs at $0.2 \mathrm{GPa}$.

- Liquid lines of descent established via polybaric fractional crystallisation follow calc-alkaline differentiation trends with continuously increasing silica and alkali contents and depletion in $\mathrm{MgO}$. Differentiation trends of cooling-dominated fractionation evolve towards peraluminous melt compositions similar to previous high-pressure isobaric crystallisation studies and do not reproduce the compositional variation observed for calc-alkaline volcanic rocks from the Cascades (Western U.S.). For decompression-dominated fractionation, the pressure-induced shift of the olivine-clinopyroxene cotectic results in a slight deflection of LLD's towards higher normative clinopyroxene keeping them metaluminous, similar to the natural volcanic record.

- Results from oxidised fractionation experiments demonstrate a fundamental control of $\mathrm{fO}_{2}$ on the chemical evolution of calc-alkaline liquids. The LLD is shifted towards clinopyroxene-rich normative compositions resulting in an excellent match of experimental melts with natural bulk rock compositions. Consequently, our data indicate that $\mathrm{fO}_{2}$ potentially plays a key role for arc magma differentiation opening new avenues for future studies on the quantification of varying redox conditions on calc-alkaline phase equilibria.

- Based on the compositional variation revealed by typical calc-alkaline rocks, polybaric fractional crystallisation alone cannot explain the natural arc magmatic differentiation trend. Mixing between differentiated basalts and intermediate liquids (andesite and/or dacite) and crystal entrainment from previously formed clinopyroxene-dominated cumulates during melt segregation are important in modifying LLD's defined by fractional crystallisation. Both processes result in an enrichment of residual melts in normative clinopyroxene and, thus, circumvent the evolution of magmas towards peraluminous compositions. However, additional experimental and petrological research is required to test and refine this model.

Supplementary Information The online version contains supplementary material available at https://doi.org/10.1007/s00410-021-01856-8.
Acknowledgements We would like to thank Lukas Martin, Eric Reusser, and Julien Allaz for assistance during SEM-EDS and EPMA analyses and Andy Huber, Andreas Jallas, and Thomas Good for technical support in the experimental labs. We are grateful to Tom Sisson, Manuel Pimenta Silva, Olivier Bachmann, and Max Schmidt for constructive and enlightening discussions. Thoughtful and constructive reviews from Mike Krawczynski, Andrea Goltz, and an anonymous reviewer as well as the editorial handling by Dante Canil are gratefully acknowledged. This work was supported by the ETH research grant ETH-14 16-1 covering F.M.

Funding Open Access funding enabled and organized by Projekt DEAL. This work was supported by the ETH research grant ETH-14 16-1 covering F.M.

Data availability Data established in this project are made available electronically as supplementary material to this manuscript.

Code availability Not applicable.

\section{Declarations}

Conflict of interest We declare no conflicts of interests.

Open Access This article is licensed under a Creative Commons Attribution 4.0 International License, which permits use, sharing, adaptation, distribution and reproduction in any medium or format, as long as you give appropriate credit to the original author(s) and the source, provide a link to the Creative Commons licence, and indicate if changes were made. The images or other third party material in this article are included in the article's Creative Commons licence, unless indicated otherwise in a credit line to the material. If material is not included in the article's Creative Commons licence and your intended use is not permitted by statutory regulation or exceeds the permitted use, you will need to obtain permission directly from the copyright holder. To view a copy of this licence, visit http://creativecommons.org/licenses/by/4.0/.

\section{References}

Allen JC, Boettcher AL, Marland G (1975) Amphiboles in andesite and basalt: I. Stability as a function of P-T- $\mathrm{fO}_{2}$. Am Miner 60:1069-1085

Almeev RR, Ariskin AA, Kimura JI, Barmina GS (2013) The role of polybaric crystallization in genesis of andesitic magmas: phase equilibria simulations of the Bezymianny volcanic subseries. J Volcanol Geoth Res 263:182-192. https://doi.org/10.1016/j. jvolgeores.2013.01.004

Alonso-Perez R, Müntener O, Ulmer P (2009) Igneous garnet and amphibole fractionation in the roots of island arcs: experimental constraints on andesitic liquids. Contrib Mineral Petrol 157:541-558. https://doi.org/10.1007/s00410-008-0351-8

Anderson AT (1973) The before-eruption water content of some high-alumina magmas. Bull Volcanol 37:530-552. https://doi. org/10.1007/BF02596890

Baker DR (2004) Piston-cylinder calibration at 400 to $500 \mathrm{MPa}$ : a comparison of using water solubility in albite melt and $\mathrm{NaCl}$ melting. Am Miner 89:1553-1556. https://doi.org/10.2138/ am-2004-1026

Barr JA, Grove TL (2010) AuPdFe ternary solution model and applications to understanding the $\mathrm{fO}_{2}$ of hydrous, high-pressure experiments. Contrib Mineral Petrol 160:631-643. https://doi. org/10.1007/s00410-010-0497-z 
Bartels KS, Kinzler RJ, Grove TL (1991) High-pressure phase-relations of primitive high-alumina basalts from Medicine Lake volcano, northern California. Contrib Mineral Petrol 108:253-270. https://doi.org/10.1007/Bf00285935

Blatter DL, Sisson TW, Hankins WB (2013) Crystallization of oxidized, moderately hydrous arc basalt at mid- to lower-crustal pressures: implications for andesite genesis. Contrib Mineral Petrol 166:861-886. https://doi.org/10.1007/s00410-013-0920-3

Blatter DL, Sisson TW, Hankins WB (2017) Voluminous arc dacites as amphibole reaction-boundary liquids. Contrib Mineral Petrol 172:27. https://doi.org/10.1007/s00410-017-1340-6

Blundy J, Cashman K (2001) Ascent-driven crystallisation of dacite magmas at Mount St Helens, 1980-1986. Contrib Mineral Petrol 140:631-650. https://doi.org/10.1007/s004100000219

Blundy J, Cashman K (2008) Petrologic reconstruction of magmatic system variables and processes. Miner, Incl Volcan Process 69:179-239. https://doi.org/10.2138/rmg.2008.69.6

Blundy JD, Sparks RSJ (1992) Petrogenesis of mafic inclusions in granitoids of the Adamello Massif, Italy. J Petrol 33:1039-1104. https://doi.org/10.1093/petrology/33.5.1039

Blundy J, Melekhova E, Ziberna L, Humphreys MCS, Cerantolo V, Brooker RA, McCammon C, Pichavant M, Ulmer P (2020) Effect of redox on $\mathrm{Fe}-\mathrm{Mg}-\mathrm{Mn}$ exchange between olivine and melt and an oxybarometer for basalts. Contrib Mineral Petrol 175:103. https://doi.org/10.1007/s00410-020-01736-7

Botcharnikov RE, Koepke J, Holtz F, McCammon C, Wilke M (2005) The effect of water activity on the oxidation and structural state of $\mathrm{Fe}$ in a ferro-basaltic melt. Geochim Cosmochim Acta 69:5071-5085. https://doi.org/10.1016/j.gca.2005.04.023

Bowen NL (1915) The later stages of the evolution of the igneous rocks. J Geol 23:1-91

Bowen NL (1928) The evolution of the igneous rocks. Princton University Press, Princton

Burnham CW (1994) Development of the Burnham model for prediction of $\mathrm{H}_{2} \mathrm{O}$ solubility in magmas. In: Carroll MR, Holloway JR (eds) Volatiles in magmas. Reviews in mineralogy and geochemistry, vol 30. Mineralogical Society of America, Washington, pp 123-130

Burnham CW, Davis NF (1974) The role of $\mathrm{H}_{2} \mathrm{O}$ in silicate melts: II. Thermodynamic and phase relations in the system NaAlSi ${ }_{3} \mathrm{O}_{8}-\mathrm{H}_{2} \mathrm{O}$ to 10 kilobars, $700{ }^{\circ} \mathrm{C}$ to $1100{ }^{\circ} \mathrm{C}$. Am J Sci 274:902-940. https://doi.org/10.2475/ajs.274.8.902

Cawthorn RG, O'Hara MJ (1976) Amphibole fractionation in calcalkaline magma genesis. Am J Sci 276:309-329. https://doi.org/ 10.2475/ajs.276.3.309

Clark SP (1959) Effect of pressure on the melting points of eight alkali halides. J Chem Phys 31:1526-1531. https://doi.org/10. $1063 / 1.1730648$

Clemens JD, Stevens G, Farina F (2011) The enigmatic sources of I-type granites: the peritectic connexion. Lithos 126:174-181. https://doi.org/10.1016/j.lithos.2011.07.004

Clemens JD, Stevens G, Mayne MJ (2021) Do arc silicic magmas form by fluid-fluxed melting of older arc crust or fractionation of basaltic magmas? Contrib Mineral Petrol. https://doi.org/10. 1007/s00410-021-01800-w

Clowe CA, Popp RK, Fritz SJ (1988) Experimental investigation of the effect of oxygen fugacity on ferric-ferrous ratios and unitcell parameters of four natural clinoamphiboles. Am Mineral 73:487-499

Collins WJ, Murphy JB, Johnson TE, Huang HQ (2020) Critical role of water in the formation of continental crust. Nat Geosci 13:331-338. https://doi.org/10.1038/s41561-020-0573-6

Cottrell E, Birner SK, Brounce M, Davis FA, Waters LE, Kelley KA (2021) Oxygen fugacity across tectonic settings. In: Moretti R, Neuville DR (eds) AGU Geophysical Monograph Series Magma Redox Geochemistry. Wiley, Hoboken, pp 33-61
Davidson J, Turner S, Handley H, Macpherson C, Dosseto A (2007) Amphibole "sponge" in arc crust? Geology 35:787-790. https:// doi.org/10.1130/G23637A.1

DePaolo DJ (1981) Trace element and isotopic effects of combined wallrock assimilation and fractional crystallization. Earth Planet Sci Lett 53:189-202. https://doi.org/10.1016/0012-821x(81) 90153-9

Dessimoz M, Müntener O, Ulmer P (2012) A case for hornblende dominated fractionation of arc magmas: the Chelan Complex (Washington Cascades). Contrib Mineral Petrol 163:567-589. https://doi.org/10.1007/s00410-011-0685-5

Du Bray EA, John DA, Sherrod DR, Evarts RC, Conrey RM, Lexa J (2006) Geochemical database for volcanic rocks of the Western Cascades, Washington, Oregon, and California. US Geol Surv Data Ser 15:49. https://doi.org/10.3133/ds155

Eichelberger JC (1975) Origin of andesite and dacite: evidence of mixing at Glass Mountain in California and at other circumPacific volcanos. Geol Soc Am Bull 86:1381-1391. https://doi. org/10.1130/0016-7606(1975)86\%3c1381:Ooaade\%3e2.0.Co;2

Erdmann S, Martel C, Pichavant M, Kushnir A (2014) Amphibole as an archivist of magmatic crystallization conditions: problems, potential, and implications for inferring magma storage prior to the paroxysmal 2010 eruption of Mount Merapi, Indonesia. Contrib Mineral Petrol 167:1016. https://doi.org/10.1007/ s00410-014-1016-4

Eugster HP (1957) Heterogeneous reactions involving oxidation and reduction at high pressures and temperatures. J Chem Phys 26:1760-1761. https://doi.org/10.1063/1.1743626

Eugster HP, Wones DR (1962) Stability relations of the ferruginous biotite, annite. J Petrol 3:82-125. https://doi.org/10.1093/petro $\log / 3.1 .82$

Foden JD, Green DH (1992) Possible role of amphibole in the origin of andesite: some experimental and natural evidence. Contrib Mineral Petrol 109:479-493. https://doi.org/10.1007/BF003 06551

Ghiorso MS, Evans BW (2008) Thermodynamics of rhombohedral oxide solid solutions and a revision of the $\mathrm{Fe}-\mathrm{Ti}$ two-oxide geothermometer and oxygen-barometer. Am J Sci 308:957-1039. https://doi.org/10.2475/09.2008.01

Ghiorso MS, Gualda GAR (2015) $\mathrm{An}_{2} \mathrm{O}-\mathrm{CO}_{2}$ mixed fluid saturation model compatible with rhyolite-MELTS. Contrib Miner Petrol 169:53. https://doi.org/10.1007/s00410-015-1141-8

Gill J (1981) Orogenic andesites and plate tectonics. Springer Verlag, Berlin

Goltz AE, Krawczynski MJ, Gavrilenko M, Gorbach NV, Ruprecht P (2020) Evidence for superhydrous primitive arc magmas from mafic enclaves at Shiveluch volcano, Kamchatka. Contrib Mineral Petrol. https://doi.org/10.1007/s00410-020-01746-5

Green TH, Ringwood AE (1968) Genesis of the calc-alkaline igneous rock suite. Contrib Mineral Petrol 18:105-162. https://doi.org/ 10.1007/BF00371806

Grove TL, Baker MB (1984) Phase-equilibrium controls on the tholeiitic versus calc-alkaline differentiation trends. J Geophys Res 89:3253-3274. https://doi.org/10.1029/JB089iB05p03253

Grove TL, Kinzler RJ, Bryan WB (1992) Fractionation of midocean ridge basalt (MORB). Geophys Monogr Ser 71:281-310. https://doi.org/10.1029/GM071p0281

Grove TL, Parman SW, Bowring SA, Price RC, Baker MB (2002) The role of an $\mathrm{H}_{2} \mathrm{O}$-rich fluid component in the generation of primitive basaltic andesites and andesites from the Mt. Shasta region, N California. Contrib Mineral Petrol 142:375-396. https://doi.org/10.1007/s004100100299

Grove TL, Elkins-Tanton LT, Parman SW, Chatterjee N, Müntener O, Gaetani GA (2003) Fractional crystallization and mantle-melting controls on calc-alkaline differentiation trends. 
Contrib Mineral Petrol 145:515-533. https://doi.org/10.1007/ s00410-003-0448-z

Grove TL, Baker MB, Price RC, Parman SW, Elkins-Tanton LT, Chatterjee N, Müntener O (2005) Magnesian andesite and dacite lavas from Mt. Shasta, northern California: products of fractional crystallization of $\mathrm{H}_{2} \mathrm{O}$-rich mantle melts. Contrib Mineral Petrol 148:542-565. https://doi.org/10.1007/s00410-004-0619-6

Hamada M, Fujii T (2008) Experimental constraints on the effects of pressure and $\mathrm{H}_{2} \mathrm{O}$ on the fractional crystallization of high-Mg island arc basalt. Contrib Mineral Petrol 155:767-790. https:// doi.org/10.1007/s00410-007-0269-6

Hamilton DL, Burnham CW, Osborn EF (1964) The solubility of water and effects of oxygen fugacity and water content on crystallization in mafic magmas. J Petrol 5:21-39. https://doi.org/10.1093/ petrology/5.1.21

Hernlund J, Leinenweber K, Locke D, Tyburczy JA (2006) A numerical model for steady-state temperature distributions in solid-medium high-pressure cell assemblies. Am Mineral 91:295-305. https:// doi.org/10.2138/am.2006.1938

Hildreth W, Moorbath S (1988) Crustal contributions to arc magmatism in the Andes of Central Chile. Contrib Mineral Petrol 98:455-489. https://doi.org/10.1007/Bf00372365

Holland T, Blundy J (1994) Non-ideal interactions in calcic amphiboles and their bearing on amphibole-plagioclase thermometry. Contrib Mineral Petrol 116:433-447. https://doi.org/10.1007/BF00310910

Holloway JR, Blank JG (1994) Application of experimental results to C-O-H species in natural melts. In: Carroll MR, Holloway JR (eds) Volatiles in magmas. Reviews in mineralogy and geochemistry, vol 30. Mineralogical Society of America, Washington, pp 187-230

Holloway JR, Burnham CW (1972) Melting relations of basalt with equilibrium water pressure less than total pressure. J Petrol 13:129. https://doi.org/10.1093/petrology/13.1.1

Holtz F, Behrens H, Dingwell DB, Johannes W (1995) $\mathrm{H}_{2} \mathrm{O}$ solubility in haplogranitic melts: compositional, pressure, and temperature dependence. Am Mineral 80:94-108. https://doi.org/10.2138/ am-1995-1-210

Hughes EC, Buse B, Kearns SL, Blundy JD, Kilgour G, Mader HM (2019) Low analytical totals in EPMA of hydrous silicate glass due to sub-surface charging: obtaining accurate volatiles by difference. Chem Geol 505:48-56. https://doi.org/10.1016/j.chemg eo.2018.11.015

Hurlimann N, Müntener O, Ulmer P, Nandedkar R, Chiaradia M, Ovtcharova M (2016) Primary magmas in continental arcs and their differentiated products: petrology of a post-plutonic dyke suite in the Tertiary Adamello Batholith (Alps). J Petrol 57:495533. https://doi.org/10.1093/petrology/egw016

Kaegi R, Muentener O, Ulmer P, Ottolini L (2005) Piston-cylinder experiments on $\mathrm{H}_{2} \mathrm{O}$ undersaturated $\mathrm{Fe}$-bearing systems: an experimental setup approaching $\mathrm{fO}_{2}$ conditions of natural calc-alkaline magmas. Am Mineral 90:708-717. https://doi.org/10.2138/am. 2005.1663

Keller CB, Schoene B, Barboni M, Samperton KM, Husson JM (2015) Volcanic-plutonic parity and the differentiation of the continental crust. Nature 523:301-307. https://doi.org/10.1038/nature14584

Knipping JL, Webster JD, Simon AC, Holtz F (2019) Accumulation of magnetite by flotation on bubbles during decompression of silicate magma. Sci Rep 9:3852. https://doi.org/10.1038/ s41598-019-40376-1

Kress VC, Carmichael ISE (1991) The compressibility of silicate liquids containing $\mathrm{Fe}_{2} \mathrm{O}_{3}$ and the effect of composition, temperature, oxygen fugacity and pressure on their redox states. Contrib Mineral Petrol 108:82-92. https://doi.org/10.1007/BF00307328

Lange RA, Carmichael ISE (1987) Densities of $\mathrm{Na}_{2} \mathrm{O}-\mathrm{K}_{2} \mathrm{O}-\mathrm{CaO}-\mathrm{MgO}-\mathrm{FeO}-\mathrm{Fe}_{2} \mathrm{O}_{3}-\mathrm{Al}_{2} \mathrm{O}_{3}-\mathrm{TiO}_{2}-\mathrm{SiO}_{2}$ liquids: new measurements and derived partial molar properties. Geochim
Cosmochim Acta 51:2931-2946. https://doi.org/10.1016/00167037(87)90368-1

Macpherson CG, Dreher ST, Thirlwall MF (2006) Adakites without slab melting: high pressure differentiation of island arc magma, Mindanao, the Philippines. Earth Planet Sci Lett 243:581-593. https://doi.org/10.1016/j.eps1.2005.12.034

Martel C, Pichavant M, Holtz F, Scaillet B, Bourdier JL, Traineau H (1999) Effects of $\mathrm{fO}_{2}$ and $\mathrm{H}_{2} \mathrm{O}$ on andesite phase relations between 2 and 4 kbar. J Geophys Res-Solid Earth 104:29453-29470. https://doi.org/10.1029/1999JB900191

Marxer F (2021) Polybaric fractional crystallisation of arc magmas - an experimental study. Zürich: Doctoral Thesis, ETH Zürich, 369 p.

Marxer F, Ulmer P (2019) Crystallisation and zircon saturation of calcalkaline tonalite from the Adamello Batholith at upper crustal conditions: an experimental study. Contrib Mineral Petrol 174:84. https://doi.org/10.1007/s00410-019-1619-x

Matjuschkin V, Brooker RA, Tattitch B, Blundy JD, Stamper CC (2015) Control and monitoring of oxygen fugacity in piston cylinder experiments. Contrib Mineral Petrol 169:9. https://doi.org/ 10.1007/s00410-015-1105-z

Melekhova E, Blundy J, Robertson R, Humphreys MCS (2015) Experimental evidence for polybaric differentiation of primitive arc basalt beneath St. Vincent, Lesser Antilles. J Petrol 56:161-192. https://doi.org/10.1093/petrology/egu074

Mills RD, Glazner AF (2013) Experimental study on the effects of temperature cycling on coarsening of plagioclase and olivine in an alkali basalt. Contrib Mineral Petrol 166:97-111. https://doi. org/10.1007/s00410-013-0867-4

Miyashiro A (1974) Volcanic rock series in island arcs and active continental margins. Am J Sci 274:321-355. https://doi.org/10.2475/ ajs.274.4.321

Müntener O, Ulmer P (2006) Experimentally derived high-pressure cumulates from hydrous arc magmas and consequences for the seismic velocity structure of lower arc crust. Geophys Res Lett 33:5. https://doi.org/10.1029/2006g1027629

Müntener O, Ulmer P (2018) Arc crust formation and differentiation constrained by experimental petrology. Am J Sci 318:64-89. https://doi.org/10.2475/01.2018.04

Müntener O, Kelemen PB, Grove TL (2001) The role of $\mathrm{H}_{2} \mathrm{O}$ during crystallization of primitive arc magmas under uppermost mantle conditions and genesis of igneous pyroxenites: an experimental study. Contrib Mineral Petrol 141:643-658. https://doi.org/10. 1007/s004100100266

Nandedkar RH (2014) Evolution of hydrous mantle-derived calcalkaline liquids by fractional crystallization at 0.7 and $0.4 \mathrm{GPa}$ - an experimental study. Zürich: Doctoral Thesis, ETH Zürich, $204 \mathrm{p}$.

Nandedkar RH, Ulmer P, Müntener O (2014) Fractional crystallization of primitive, hydrous arc magmas: an experimental study at $0.7 \mathrm{GPa}$. Contrib Mineral Petrol 167:1015. https://doi.org/10. 1007/s00410-014-1015-5

Neave DA, Maclennan J (2020) Clinopyroxene dissolution records rapid magma ascent. Front Earth Sci 8:188. https://doi.org/10. 3389/feart.2020.00188

Osborn EF (1959) Role of oxygen pressure in the crystallization and differentiation of basaltic magma. Am J Sci 257:609-647. https://doi.org/10.2475/ajs.257.9.609

Osborn EF (1962) Reaction series for subalkaline igneous rocks based on different oxygen pressure conditions. Am Mineral 47:211-226

Pichavant M, Macdonald R (2007) Crystallization of primitive basaltic magmas at crustal pressures and genesis of the calc-alkaline igneous suite: experimental evidence from St Vincent, Lesser Antilles arc. Contrib Mineral Petrol 154:535-558. https://doi.org/10.1007/ s00410-007-0208-6 
Reubi O, Blundy J (2009) A dearth of intermediate melts at subduction zone volcanoes and the petrogenesis of arc andesites. Nature 461:1269-1273. https://doi.org/10.1038/nature08510

Ridolfi F, Renzulli A (2012) Calcic amphiboles in calc-alkaline and alkaline magmas: thermobarometric and chemometric empirical equations valid up to $1,130{ }^{\circ} \mathrm{C}$ and $2.2 \mathrm{GPa}$. Contrib Mineral Petrol 163:877-895. https://doi.org/10.1007/s00410-011-0704-6

Ridolfi F, Renzulli A, Puerini M (2010) Stability and chemical equilibrium of amphibole in calc-alkaline magmas: an overview, new thermobarometric formulations and application to subductionrelated volcanoes. Contrib Mineral Petrol 160:45-66. https://doi. org/10.1007/s00410-009-0465-7

Rutherford MJ (2008) Magma ascent rates. Miner Incl Volcan Process 69:241-271. https://doi.org/10.2138/rmg.2008.69.7

Schwandt CS, Mckay GA (2006) Minor- and trace-element sector zoning in synthetic enstatite. Am Mineral 91:1607-1615. https://doi. org/10.2138/am.2006.2093

Shishkina TA, Botcharnikov RE, Holtz F, Almeev RR, Portnyagin MV (2010) Solubility of $\mathrm{H}_{2} \mathrm{O}$ - and $\mathrm{CO}_{2}$-bearing fluids in tholeiitic basalts at pressures up to $500 \mathrm{MPa}$. Chem Geol 277:115-125. https://doi.org/10.1016/j.chemgeo.2010.07.014

Sisson TW, Grove TL (1993a) Experimental investigations of the role of $\mathrm{H}_{2} \mathrm{O}$ in calc-alkaline differentiation and subduction zone magmatism. Contrib Mineral Petrol 113:143-166. https://doi.org/10. 1007/BF00283225

Sisson TW, Grove TL (1993b) Temperatures and $\mathrm{H}_{2} \mathrm{O}$ contents of low$\mathrm{MgO}$ high-alumina basalts. Contrib Mineral Petrol 113:167-184. https://doi.org/10.1007/BF00283226

Sisson TW, Ratajeski K, Hankins WB, Glazner AF (2005) Voluminous granitic magmas from common basaltic sources. Contrib Mineral Petrol 148:635-661. https://doi.org/10.1007/s00410-004-0632-9

Sparks RSJ, Marshall LA (1986) Thermal and mechanical constraints on mixing between mafic and silicic magmas. J Volcanol Geoth Res 29:99-124. https://doi.org/10.1016/0377-0273(86)90041-7

Spear FS, Kimball KL (1984) RECAMP - a FORTRAN-IV program for estimating $\mathrm{Fe}^{3+}$ contents in amphiboles. Comput Geosci 10:317-325. https://doi.org/10.1016/0098-3004(84)90029-3

Stamper CC, Melekhova E, Blundy JD, Arculus RJ, Humphreys MCS, Brooker RA (2014) Oxidised phase relations of a primitive basalt from Grenada, Lesser Antilles. Contrib Mineral Petrol 167:954. https://doi.org/10.1007/s00410-013-0954-6
Tang M, Erdman M, Eldridge G, Lee CTA (2018) The redox "filter" beneath magmatic orogens and the formation of continental crust. Sci Adv 4:1-7. https://doi.org/10.1126/sciadv.aar4444

Tatsumi Y, Takahashi T (2006) Operation of subduction factory and production of andesite. J Mineral Petrol Sci 101:145-153. https:// doi.org/10.2465/jmps.101.145

Thompson AB, Matile L, Ulmer P (2002) Some thermal constraints on crustal assimilation during fractionation of hydrous, mantlederived magmas with examples from central alpine batholiths. J Petrol 43:403-422. https://doi.org/10.1093/petrology/43.3.403

Turner SJ, Langmuir CH (2015) The global chemical systematics of arc front stratovolcanoes: evaluating the role of crustal processes. Earth Planet Sci Lett 422:182-193. https://doi.org/10.1016/j.epsl. 2015.03.056

Ulmer P (2007) Differentiation of mantle-derived calc-alkaline magmas at mid to lower crustal levels: experimental and petrologic constraints. Periodico Di Mineralogia 76:309-325

Ulmer P, Kaegi R, Müntener O (2018) Experimentally derived intermediate to silica-rich arc magmas by fractional and equilibrium crystallization at $1.0 \mathrm{GPa}$ : an evaluation of phase relationships, compositions, liquid lines of descent and oxygen fugacity. J Petrol 59:11-58. https://doi.org/10.1093/petrology/egy017

Villiger S, Ulmer P, Müntener O, Thompson AB (2004) The liquid line of descent of anhydrous, mantle-derived, tholeiitic liquids by fractional and equilibrium crystallization-an experimental study at 1.0 GPa. J Petrol 45:2369-2388. https://doi.org/10.1093/petro $\operatorname{logy} /$ egh042

Waters LE, Lange RA (2015) An updated calibration of the plagioclase-liquid hygrometer-thermometer applicable to basalts through rhyolites. Am Mineral 100:2172-2184. https://doi.org/ 10.2138/am-2015-5232

Wood BJ, Banno S (1973) Garnet-orthopyroxene and orthopyroxeneclinopyroxene relationships in simple and complex systems. Contrib Mineral Petrol 42:109-124. https://doi.org/10.1007/BF003 71501

Publisher's Note Springer Nature remains neutral with regard to jurisdictional claims in published maps and institutional affiliations. 